\title{
Stem cell transcription factor SOX2 in synovial sarcoma and other soft tissue tumors
}

\author{
Dissertation \\ in Partial Fulfillment of the Requirements for the Degree of \\ Doctor Medicinae (Dr. Med.) \\ Submitted to the Faculty Council of the School of Medicine \\ at Friedrich-Schiller University of Jena
}

By MSc. Hebatalla Zayed

Born on 20.09.1981 in Dubai, United Arab Emirates 
Reviewers:

1.

2.

3.

Date of public disputation: 


\section{Table of Contents}

Page

No.

1. Summary 1

2. Introduction 5

2.1 Stem cells and embryonic stem cells $\quad \mathbf{5}$

2.2 Induced pluripotent stem cells and the Yamanaka Factors $\quad 7$

2.3 Cancer and cancer stem cells $\quad \mathbf{1 0}$

2.4 Sox2 12

2.5 Soft Tissue Tumors $\quad 14$

2.5.1 Epidemiology $\quad \mathbf{1 4}$

2.5.2 Classification $\quad \mathbf{1 5}$

2.5.3 Pathogenesis $\quad \mathbf{1 5}$

2.5.4 Environmental factors $\quad \mathbf{1 6}$

$\begin{array}{ll}2.5 .5 \text { Oncogenic viruses } & 17\end{array}$

2.5.6 Immunologic factors

2.5.7 Genetic factors $\quad \mathbf{1 8}$

2.5.8 Clinical features $\mathbf{1 8}$

2.5.9 Diagnosis $\quad \mathbf{1 8}$

2.5.10 Grading and staging $\quad \mathbf{2 0}$

2.5.11 Prognosis

2.6 Synovial sarcoma $\quad \mathbf{2 3}$

2.7 BAF complex and genetic mutations $\quad \mathbf{2 4}$

3. Aim of work $\quad 26$

4. Published original work $\quad 27$

5. Discussion $\quad 35$

6. Conclusion $\quad 44$

7. References $\quad 45$

8. Appendix $\quad 65$ 


\begin{tabular}{lll} 
& \multicolumn{1}{c}{ Abbreviations } \\
AEG & $:$ Anophthalmia-esophageal-genital \\
AJC & $:$ American Joint Committee \\
BAF & $:$ Brahma-associated factor \\
ChIPSeq & $:$ Chromatin immunoprecipitation sequencing \\
CSC & $:$ Cancer stem cell \\
EMA & $:$ Epithelial membrane antigen \\
EMT & $:$ Epithelial mesenchymal transition \\
ES & $:$ Embryonic stem \\
EZH2 & $:$ Enhancer of zeste homologue 2 \\
FAP & $:$ Familial adenomatous polyposis \\
FISH & $:$ Fluorescence in situ hybridization \\
FNCLCC & $:$ Fédération Nationale des Centres de Lutte Contre le Cancer \\
H3K27me3 & $:$ Trimethylated histone \\
HV8 & $:$ Herpesvirus 8 \\
IPSCs & $:$ Induced pluripotent stem cells \\
MPNST & $:$ Malignant peripheral nerve sheath tumor \\
RAAS & $:$ Radiation associated angiosarcoma \\
RT-PCR & $:$ Reverse transcriptase polymerase chain reaction \\
SCC & $:$ Squamous cell carcinoma \\
SCLC & $:$ Small-cell lung cancer \\
SEER & $:$ Surveillance, Epidemiology and End Results \\
SRY-box 2 & $:$ Sex determining region Y-box 2 \\
STA & $:$ Synovial sarcoma \\
STicroarrays
\end{tabular}




\section{SUMMARY}

\section{Background}

Soft tissue tumors, as an important oncology domain, entail different entities and are challenging regarding diagnosis and therapy. Here, we focused on synovial sarcoma alongside with other soft tissue tumors and specifically analyzed the expression and amplification of the gene SOX2 which has the full name SRY (sex determining region Y)-box2. SOX2 is a transcription factor responsible for the pluripotency of undifferentiated embryonic stem cells, promoting cellular proliferation and promoting invasion, migration and metastases in melanoma and other tumors. We also tested AntiHistone H3-trimethyl K27 (H3K27me3) expression in SOX2 positive cases in an attempt to correlate SOX2 gene expression with the posttranslational protein modification $\mathrm{H} 3 \mathrm{~K} 27 \mathrm{me} 3$, both of which having been associated with stemness features of cancer cells.

\section{Methodology}

In our study, we included all samples $(n=60)$ of synovial sarcoma at the Friedrich-Schiller University hospital of Jena (Germany) between January 2013 and December 2015 in a retrospective observational manner. We excluded cases whose histopathological material was not available anymore in the institute $(n=6)$ and cases $(n=4)$ whose paraffin block was not optimal for further investigation. Clinicopathological and Immunohistochemical analysis were performed by our institutional pathology team according to standard diagnostic protocols e.g. using antibodies against EMA, Bc12, PanCK, CK7, CD34, Ki67 and S100. Molecular confirmation of the diagnosis was routinely performed by FISH and/or PCR to detect the $\mathrm{t}(\mathrm{x} ; 18)$ translocation. We also employed tissue microarrays of different soft tissue tumors to compare the expression in synovial sarcoma with other sarcoma entities. Results were collected, tabulated and statistically analyzed.

\section{Results}

About $60 \%$ of all synovial sarcoma cases were positive to Sox 2 . Meanwhile out of 343 soft tissue tumors, varying from nodular fasciitis to undifferentiated pleomorphic sarcoma, only 13 cases $(3.8 \%)$ were Sox 2 positive. Of these, $11(84.6 \%)$ were 
undifferentiated high grade pleomorphic sarcoma. Out of 35 Sox2 positive synovial sarcoma cases, $25(71,4 \%)$ were H3K27me3 positive and $10(28,6 \%)$ were negative. SOX2 amplification was not detectable in 6 randomly chosen synovial sarcoma cases showing SOX2 protein expression.

\section{Conclusion}

Sox2, a principal stem-cell transcription factor, is evidently involved in the tumorigenesis of many tumor entities. In soft tissue tumors, however, expression is largely restricted to synovial sarcoma. Immunohistochemical detection of SOX2 can thus help in the diagnostic challenge in differentiating synovial sarcoma from other soft tissue tumors. H3K27me3 was also found to be positive in the majority of Sox2-positive synovial sarcomas and this correlates with the idea that these tumors might have a pluripotent cell population as tumor-initiating cells. We think that this finding supports the hypothesis of synovial sarcoma as product of pluripotent mesenchymal stem cell populations rather than being derived from mutations in terminally differentiated cells. The results may add to the diagnostic scheme for synovial sarcoma diagnosis. Moreover, Sox 2 might reveal a molecular approach in cancer treatment, namely by targeting epigenetic modulators that seems to play a role in SOX2 gene regulation. 


\section{Zusammenfassung}

\section{Hintergrund der Studie:}

Weichteiltumoren, eine wichtige onkologische Domäne, setzen sich aus unterschiedliche Entitäten zusammen und sind diagnostisch und therapeutisch schwierig. Hier konzentrierten wir uns auf das Synovialsarkom, wie auch andere Weichteiltumore, und analysierten speziell die Expression und Amplifikation des Gens SOX2, das mit vollem Namen SRY (sex determining region Y)-Box2 heisst. SOX2 ist ein Stammzell-Transkriptionsfaktor, der für die Pluripotenz undifferenzierter embryonaler Stammzellen verantwortlich ist und die Zellproliferation, Invasion, Migration und Metastasen bei Melanomen und anderen Tumoren fördert. Daneben testeten wir die Anti-Histon-H3-Trimethyl-K27 (H3K27me3)-Expression in den Sox2positiven Fällen, um die SOX2 Expression mit der posttranslationalen Proteinmodifikation H3K27me3 zu korrelieren, beide Marker wurden mit Stamzellcharakteristika von Krebszellen assoziiert.

\section{Methodik:}

In unserer Studie wurden alle Synovialsarkome $(n=60)$ zwischen Januar 2013 und Dezember 2015 an der Friedrich-Schiller-Universitätsklinik in Jena (Deutschland) retrospektiv betrachtet. Wir schlossen Fälle aus, deren histopathologisches Material nicht mehr im Institut $(n=6)$ verfügbar oder deren Paraffinblöcke für eine weitere Analyse ungenügend waren $(n=4)$. Klinisch-pathologische und immunhistochemische Analysen wurden von qualifizierten Mitarbeitern des Institut für Pathologie nach Standard-Diagnoseprotokollen etwa unter Verwendung von Antikörpern gegen EMA, Bc12, PanCK, CK7, CD34, Ki67 und S100 durchgeführt. Die molekulare Bestätigung der Diagnose erfolgte routinemäßig durch FISH und/oder PCR-Analyse, um die t(x;18) Translokation nachzuweisen. Wir haben in dieser Studie auch Gewebe-Microarrays verschiedener Weichteiltumoren eingesetzt, um die Expression in Synovialsarkomen und anderen Sarkom-Entitäten zu vergleichen. Die Ergebnisse wurden gesammelt, tabelliert und statistisch untersucht. 


\section{Ergebnisse}

Etwa $60 \%$ aller Fälle von Synovialsarkomen waren positiv für Sox2. Von 343 Weichteiltumoren, die von der nodulären Fasziitis bis $\mathrm{zu}$ undifferenziertem pleomorphem Sarkom reichten, waren nur 13 Fälle (3,8\%) Sox2-positiv. Von diesen waren $11(84,6 \%)$ undifferenzierte hochgradige pleomorphe Sarkome. Von 35 Sox2positiven Synovialsarkomen waren 25 (71, 4\%) H3K27me3-positiv und 10 (28, 6\%) negativ. Eine SOX2 Amplifikation war nicht nachweisbar in 6 zufällig ausgewählten Synovialsarkomen mit SOX2 Expression.

\section{Schlussfolgerungen}

Sox2, ein Hauptstammzelltranskriptionsfaktor, ist offensichtlich an der Tumorigenese vieler Tumorentitäten beteiligt. In Weichtumoren ist die Expression jedoch weitgehend beschränkt auf Synovialsarkome. Der immunhistochemische SOX2 Nachweis kann damit hilfreich sein in der bisweilen schwierigen differenzialdiagnostischen Abgrenzung dieser Entität von anderen Weichteiltumoren. H3K27me3 war ebenfalls nachweisbar in den meisten Sox2-positiven Synovialsarkomtumoren und korreliert damit mit der Vorstellung, dass diese Tumoren eine pluripotente mesenchymale Stammzell-Population als tumorinitiierende Zellen aufweisen könnten. Wir denken, dass dieser Befund die Hypothese stützt, dass das Synovialsarkom eher ein Produkt pluripotenter mesenchymaler Stammzellpopulationen ist und nicht auf die Mutation terminal differenzierter Zellen zurückgeht. Die Ergebnisse könnten das diagnostische Schema für Synovialsarkome bereichern. Darüberhinaus könnte sich SOX2 als ein molekularer Ansatz in der Krebstherapie entpuppten in dem Sinne einer zielgerichteten Beeinflussung epigenetischer Modulatoren, die offenbar bei der Genregulation von SOX2 eine wichtige Rolle spielen. 


\section{INTRODUCTION}

\subsection{Stem cells and embryonic stem cells}

Stem cells are characterized by unlimited self-renewal and they also have the capacity to differentiate into virtually all tissue types (Takashi et al. 2007; Takashi and Yamanaka 2006). Increasing effort is put in the improvement of stem cell transplantation therapies to revert the damage that is done by diseases such as Alzheimer's and Parkinson's diseases. In other closely related fields like spinal cord injury, important progress has been made using stem cells to treat patients (Pen et al. 2016).

Embryonic stem (ES) cells are pluripotent stem cells derived from the inner cell mass of the early stage blastocyst (Yu \&Thomson 2008). Self-renewal is crucial to stem cell function, because it is required to persist for the life-time of the animal. Moreover, whereas stem cells from different organs may vary in their developmental potential, all stem cells must self-renew and regulate the relative balance between self-renewal and differentiation (Tannishtha et al. 2001). ES cells possess the capacity of unlimited selfrenewal while maintaining pluripotency. Their ability to differentiate into all cell types of the three embryonic germ layers makes them interesting candidates for cell replacement therapies and has led to the identification of three core transcription factors that are essential for maintenance of ES cells: Oct4, Sox2 and Nanog (Chen \& Daley 2008). Many stem cell-specific transcription factors, including the pluripotency transcription factors, Oct4, Nanog and Sox2 function in combinatorial complexes to regulate the expression of loci, which are involved in embryonic stem (ES) cell pluripotency and cellular differentiation (Kashyap et al. 2009).

Considerable effort has also been invested in attempts to dedifferentiate somatic cells towards pluripotency, a strategy that could be used for personalized regenerative medicine. One approach is to virally induce exogenous expression of transcription factors forming induced pluripotent stem cells (Johansson et al. 2010).

As well as the experimental induction of pluripotency is done by somatic cell nuclear transfer (Byrne et al. 2007), nuclear programming/cell fusion experiments (Lluis 
et al. 2008), and most recently by retroviral introduction of the four critical genes, now sometimes referred to as Yamanaka factors: Oct4, Sox2, Klf4 and c-Myc or a combination of Oct4, Sox2, Nanog and Lin28 ( $\mathrm{Yu}$ et al. 2007). This technique has permitted the reprogramming of multiple distinct mouse and human differentiated cell types to yield induced pluripotent stem (iPS) cells (Yamanaka et al. 2008). These iPS cells are similar to embryonic stem (ES) cells in morphology, proliferation and capacity to form teratomas (Takahashi et al. 2006).

A

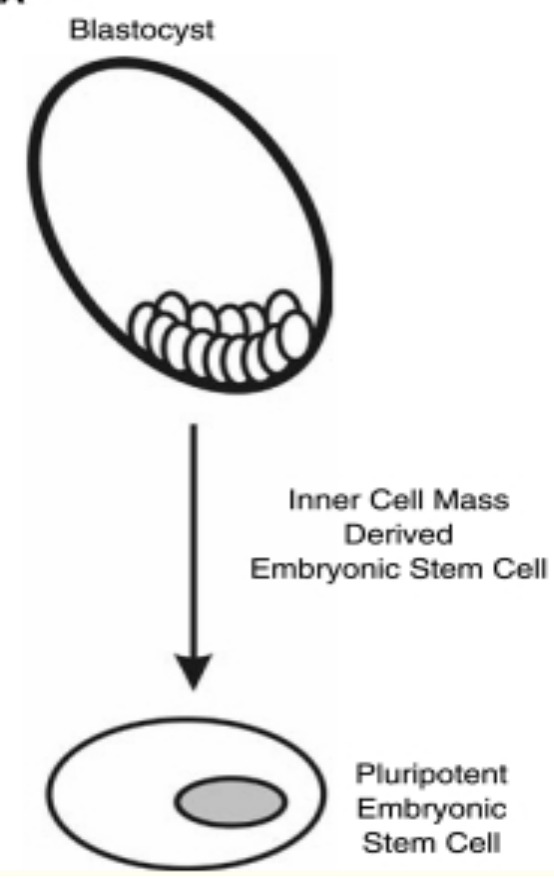

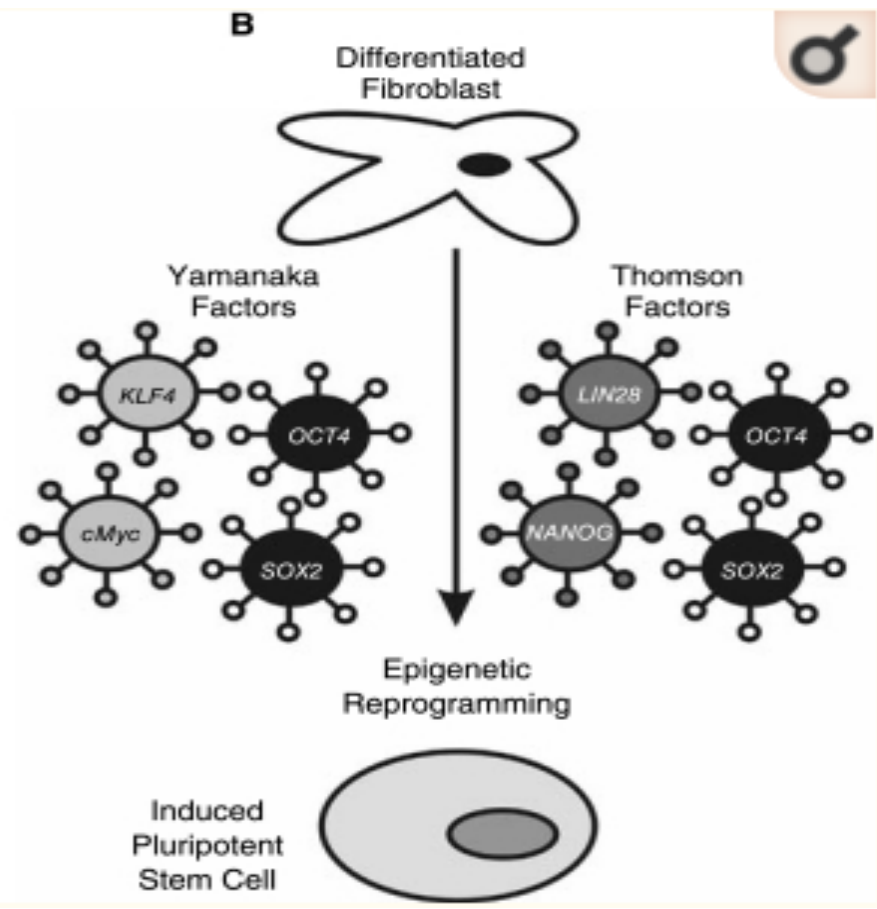

Fig 1: Pluripotent stem cells can be derived from cells isolated from the inner cell mass of early stage blastocysts (A) or experimentally derived by epigenetic reprogramming of differentiated adult cell types (B). Greatest reprogramming efficiency is achieved when combinations of 4 factors, OCT4, SOX2, c$M Y C$, and KLF4, or OCT4, SOX2, NANOG, and LIN28 genes are introduced into the differentiated cell. However, OCT4 and SOX2 appear critically required to induce pluripotency (Kashyap et al. 2009).

The highest efficiencies of induced pluripotency are achieved when all four factors (Yamanaka factors) were utilized; however c-Myc and Klf4 have been shown to be dispensable for somatic cell reprogramming to pluripotency under specific culture conditions (Nakagawa et al. 2008). Specifically, the histone deacetylase inhibitor valproic acid (VPA) both enhances the efficiency of iPS derivation by the combined four factors and permits the derivation of iPS cells using just Oct4 and Sox2 (Huangfu 
et al. 2008). These studies indicate that Oct4 and Sox 2 are critical factors required for maintaining self-renewal and pluripotency of mouse and human stem cells (Guo G et al. 2009).

Two major studies have demonstrated that Oct4, Nanog and Sox2 share a substantial fraction of target genes and in fact, co-occupy genes in both mouse and human ES cells (Boyer et al. 2005). As reported by Boyer and colleagues, these genes occupy collectively about $10 \%$ of the promoters in the human genome. About half of the promoter regions bound by Oct 4 were also bound by Sox 2 and $90 \%$ of these doubly bound genes were in turn bound by Nanog (Boyer et al. 2008). Moreover, the OCT4, SOX2 and NANOG-binding sites were in close proximity, further confirming that the proteins work in concert (Loh et al. 2006).

Oct4, Nanog, Sox 2 and a number of associated transcription factor proteins activate and maintain the expression of genes involved in self-renewal, while simultaneously repressing genes that mediate differentiation ( $\mathrm{Wu}$ et al. 2006). Thus Oct4, Nanog and Sox2 form a self-reinforcing and intricately connected network that preserves ES cell character (Yang et al. 2008).

\subsection{Induced pluripotent stem cells and the Yamanaka Factors}

In 2006, Shinya Yamanaka was the first to successfully reprogram cells using four distinct factors, thereby generating induced pluripotent stem cells (iPSCs) from terminally differentiated fibroblasts. IPSCs can be established by the over expression of four key transcription factors: Oct4, Klf4, Sox2 and c-Myc (OSKM) (Takashi et al. 2007; Takashi and Yamanaka 2006). One of the major advantages of iPSCs is that they can be made autologous and can provide a sufficient quantity of cells by culturing, making the use of other stem cell sources unnecessary (Pen et al. 2016).

Reprogramming of any somatic cell type can be achieved by initiating several synergistic processes. In the process of reprogramming, induced pluripotency elicits several transcription waves driven by c-Myc/Klf4 and Oct4/Sox2/Klf4. The expression levels of distinct pluripotency genes (alkaline phosphatase (AP), stage specific embryonic antigen (SSEA), Nanog and Oct4) increase step wise (Brambrink et al. 
2008), and upon achieving stable pluripotency levels, their DNA methylation patterns are changed (Polo et al. 2012). Nonetheless, the exact mechanisms of reprogramming still remain unclear. Obviously the reprogramming factors reactivate an endogenous pluripotency circuitry by re-inducing the cells' capacity for unlimited growth without inducing genetic alterations, as it is frequently observed in cancer (Polo et al. 2012).

It has been demonstrated that abbreviated reprogramming factor expression pattern results in dysplasia and tumor formation in vivo, thus suggesting that OKSM has an impact on epigenetic changes that are substantially involved in the regulation of cell growth and tumorigenesis (Ohnishi et al. 2014). This observation is corroborated by the fact that iPSCs form teratomas upon implantation in vivo (Magnuson et al. 1982). Of note, human iPSCs develop teratomas more efficiently and faster than human embryonic stem cells (Gutierrez-Aranda et al.2010; Avior et al. 2015).

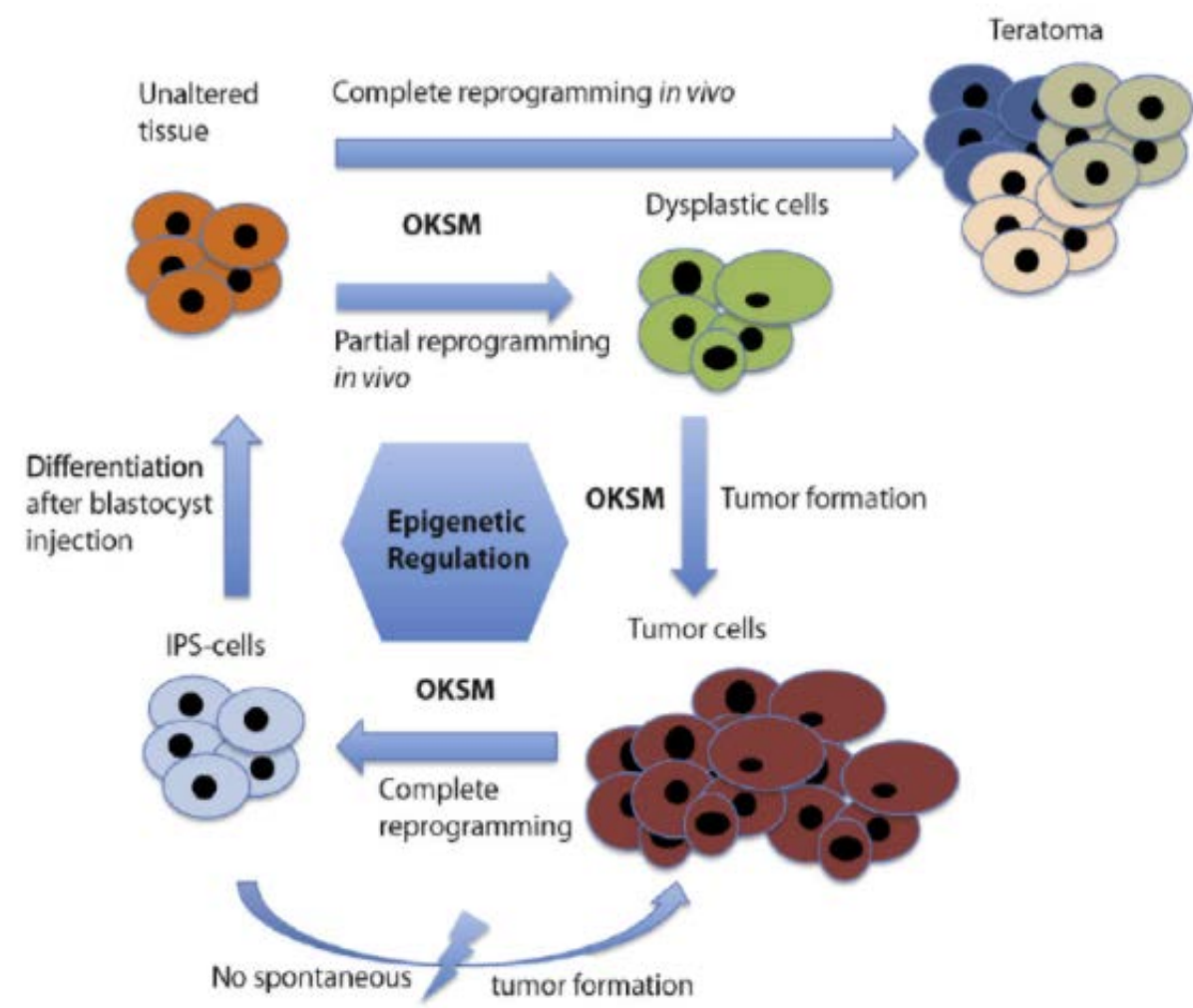

Fig 2: In vivo overexpression of the four pluripotency factors OCT4, c-MYC, KLF4 and SOX2 (OSKM) leads to epigenetic changes resulting in dysplasia. Extension of OSKM overexpression subsequently drives tumor formation. Both dysplasia and tumor formation result from an incomplete reprogramming process. Cells derived from these tumors can be fully reprogrammed towards unaltered iPSCs that do not have tendencies to re-initiate tumorigenesis after blastocyst injection. In case of complete in vivo reprogramming, teratoma formation becomes apparent. Figure is adapted from Ohnishi et al. (2014). 
Several studies have assigned the OKSM factors to tumorigenesis. Abad et al. were the first to successfully reprogram in vivo by transiently inducing OSKM, resulting in teratomas formation, and detection of fully reprogrammed cells in various tissue types. The presence of the niche in vivo even allowed superior reprogramming to the totipotent state (Abad et al. 2013). Intriguingly, further studies showed that partial or incomplete reprogramming induced particular tumor types in vivo (Ohnishi et al. 2014).

More importantly, up regulation of these proteins was associated closely with tumor metastases and poor prognosis in various human malignancies including prostate cancer, lung adenocarcinoma, gliomas, rectal cancer, gastric carcinoma and oral squamous cell carcinoma (Chiou et al. 2010; Guo et al. 2011; Matsuoka et al. 2012).

The mesenchymal phenotypic changes by increased motility and invasiveness of epithelial tumor cells are known as epithelial-mesenchymal transition (EMT). EMT is defined by the loss of epithelial morphology and the acquisition of a mesenchymal phenotype, which is initially found to be a central program in early embryonic morphogenesis (Lim et al. 2012).

In a few years, evidence has mounted for EMT as the key means through which cancer cells acquire more highly mobile potentials to migrate and metastasize to distant sites during tumor progression (Scheel and Weinberg 2011). E-cadherin, a classical cadherin from the cadherin superfamily, is required for maintaining epithelial cell plasticity. N-cadherin, known as an important member of the cadherin family that mediates calcium-dependent adhesion, is normally expressed in mesenchymal cells. Loss of E-cadherin and increased $\mathrm{N}$-cadherin expression (E/N cadherin switch) is now defined as a major hallmark of EMT (Nakajima et al. 2004; Werling et al. 2011).

Over the past few years, accumulating data has demonstrated that EMT correlates closely with the acquisition of stem cells-like properties in cancer cells (Polyak et al. 2009; Sarkar et al. 2012).

Luo et al. showed that overexpression of Sox2, Oct4 and Nanog were significantly associated with high expression of N-cadherin, but adversely with low Ecadherin expression (except SOX2). Additionally, overexpression of these proteins 
correlated strongly with the expression of Snail, a central transcription factor as Ecadherin repressor (Luo et al. 2013).

In the kidney, OKSM-induced tumors bear features of a Wilm's tumor, a common pediatric cancer. Interestingly, these tumors only display epigenetic alterations, as indicated by global changes in their DNA methylation patterns (Müller et al. 2016).

Interestingly, reprogramming of OKSM-induced tumors resulted in nontumorigenic iPSCs that contributed to regular organ formation upon subsequent differentiation in vivo. This indicates that reprogramming with the Yamanaka factors primarily leads to epigenetic alterations, generating a "cancer-poised" but not yet “cancer-committed" state (Ohnishi et al. 2014).

\subsection{Cancer and cancer stem cells}

Similar to normal tissues, cancer compromise heterogeneous cell populations with distinct phenotypes, functions and gene expression profiles (Marte 2013). The phenotypic characteristics of some cancer cells, particularly of poorly differentiated to undifferentiated tumors have been found to be quite similar to undifferentiated embryonic cells (Curry et al. 2015).

A tumor can be viewed as an aberrant organ initiated by a tumorigenic cancer cell that acquired the capacity for indefinite proliferation through accumulated mutations (Reya et al. 2001). If one views a tumor as an abnormal organ, then the principles of normal stem cell biology can be applied to understand better how tumors develop (Kummermehr 2001). Both normal stem cells and tumorigenic cells have extensive proliferative potential and the ability to give rise to new (normal and abnormal) tissues. Both tumors and normal tissues are composed of heterogeneous combinations of cells, with different phenotypic characteristics and different proliferative potentials (Nowell 1986).

Because most tumors have a clonal origin (Fearon et al. 1987), tumorigenic cancer cells must give rise to phenotypically diverse progeny, including cancer cells with indefinite proliferative potential, as well as cancer cells with limited or no proliferative potential. This suggests that tumorigenic cancer cells undergo processes 
that are analogous to the self-renewal and differentiation of normal stem cells (Reya et al. 2001).

Both normal stem cells and tumorigenic cells give rise to phenotypically heterogeneous cells that exhibit various degrees of differentiation. Thus, tumorigenic cells can be thought of as cancer stem cells that undergo an aberrant and poorly regulated process of organogenesis analogous to what normal stem cells do (Sell et al. 1994)

The cancer stem cell (CSC) hypothesis posits that tumors may be initiated and maintained by a subset of cells that maintain or acquire stem-cell properties and that each tumor contains a small subpopulation of cells that have the ability to differentiate into multiple cell lineages and self-renew (Jordan et al. 2006; Reya et al. 2001). Cancer stem cells or cancer stem-like cells have been identified in several solid tumor types such as breast cancer and colon cancer (Al-Hajj et al. 2003) This subpopulation is closely associated not only with carcinogenesis, but also with recurrence and metastasis of tumors (Jordan CT et al. 2006).

Small numbers of stem cells are believed to exist in most if not all adult tissues (Blanpain et al. 2009). Adult stem cells can evade the stringent genetic controls of their normal pathways of cellular differentiation and proliferation and give rise to cancer. Cancer stem/initiating cells have been defined as a subset of cancer cells that have the exclusive ability of self-renewal and cause the heterogeneous lineages of cancer cells that comprise the tumor (Hill et al. 2007).

These cancer stem cells are implicated in cancer initiation, malignant potential, metastatic progression, and in the post treatment recurrence of many human cancer types (Dalerba et al. 2008). Stem cell-specific proteins, including Oct4, Nanog and Zfp42/Rex1 are implicated in some cancers (Chiou et al. 2008). Histologically poorly differentiated tumors showed preferential overexpression of genes normally enriched in ES cells. Activation targets of Nanog, Oct4, Sox 2 and c-Myc are more frequently overexpressed in poorly differentiated tumors than in well-differentiated tumors (BenPorath et al. 2008). It appears that the genes active in both ES cells and cancer stem cells are controlled by a few master regulatory genes (Wong et al. 2008) 


\subsection{Sox2}

SRY(sex determining region Y)-box2, also known as Sox2, is a transcription factor that is essential for maintaining self-renewal or pluripotency of undifferentiated embryonic stem cells and plays a critical role in maintenance of embryonic and neural stem cells (Rizzino 2009). The Sox2 gene is located on chromosome 3q26.3-q27, belongs to the SoxB1 group and encodes for a protein consisting of 317 amino acids (Collignon et al. 1996). Sox2 research thus far has heavily emphasized its crucial role in stem cell maintenance, lineage fate determinant and as a necessary factor to reprogram somatic cells back towards pluripotency (Takahshi and Yamanaka 2006).

Varying levels of SOX2 affect embryonic stem cells' fate of differentiation. SOX2 inhibits differentiation into mesoderm germ layer and promotes differentiation into neural ectoderm germ layer (Thomson et al. 2011). A study conducted in Milano, Italy showed, through the development of a knockout model, that deficiency of SOX2 results in neural malformations and eventually fetal death, further underlying SOX2's vital role in embryonic development (Ferri et al. 2004).

In addition to its fundamental role in the maintenance of embryonic stem cells, SOX2 is important during embryonic development of gastrointestinal organs: it is expressed in the developing foregut and gastric epithelium. SOX2 co-localizes with p63 in the basal layer of the esophagus and is critical in the maintenance of the stratified squamous epithelium; however it is down regulated in intestinal metaplasia of the stomach and esophagus (Long and Hornick. 2009).

In neurogenesis, SOX2 is expressed throughout developing cells in the neural tube as well as in proliferating central nervous system progenitors (Graham et al. 2003). Cells expressing SOX2 are capable of both producing cells identical to themselves and differentiated neural cell types, two necessary hallmarks of stem cells (Suh et al. 2007).

In diseases, SOX2 alterations have been associated with developmental maladies, such as anophthalmia-esophageal-genital (AEG) syndrome which occurs when there is a heterozygous mutation of Sox 2 that leads to abnormal development of ectodermal and endodermal tissues (Williamson et al. 2006). 
Cancer is a disease characterized by determined hallmarks, some of which are: sustained proliferative signaling, activation of invasion and metastases, and evasion of cell death (Hanahan and Weinberg, 2011). The orchestration of tumor initiation and maintenance has been shown in some cancers to be driven by cancer stem cells (CSCs). These cells may acquire tumor-initiating and self-renewal properties through similar molecular mechanisms governing cellular reprogramming (Vazquez-Martin et al. 2013).

Sussman and colleagues discovered that the ubiquitin-specific protease 22 (USP22) is responsible for controlling the cellular transition from stemness towards differentiation (Sussman et al. 2013). Moreover they found USP22 represses the SOX2 promoter in order to control the embryonic stem cell transition from self-renewal to differentiation (Sussman et al. 2013). Therefore, not only is Sox 2 an essential stem cell marker but its suppression is mandatory for cellular differentiation. For these reasons, Sox2 has been heavily investigated in CSCs in several cancer types (Weina and Utikal 2014)

SOX2 amplification has been found in several cancer types including glioblastoma, small-cell lung cancer (SCLC) and many forms of squamous cell carcinoma (SCC) (Rudin et al. 2012).

SOX2 has been shown to promote cellular proliferation in breast, prostate, pancreatic and cervical cancers (Herreros-Villanueva et al. 2013), evade apoptotic signals in prostate, gastric cancer and non-small cell lung carcinoma (HerrerosVillanueva et al. 2013; Chen et al. 2013) and promote invasion, migration and metastases in melanoma, colorectal glioma, gastric, ovarian cancer and hepatocellular carcinoma (Sun et al. 2013; Lou et al. 2013).

Cellular proliferation is tightly regulated by Sox 2 in many cancer types. Sox 2 knockdown in pancreatic cancer cells resulted in cell growth inhibition through cell cycle arrest, not apoptosis (Herreros-Villanueva et al. 2013). When Sox2 was over expressed, cell proliferation was promoted through cyclinD3 (Herreros-Villanueva et al. 2013). 
Additionally, Fang and colleagues found in lung small cell carcinoma (LSCC), SOX2-silencing inhibited cellular proliferation via the up regulation of BMP4 (Fang et al. 2014). After performing chromatin immunoprecipitation and luciferase experiments, SOX2 was found to transcriptionally repress the BMP4 promoter. The authors therefore suggest that BMP4 is playing a tumor suppressor role in LSCC, while SOX2 repression of BMP4 transcription causes cell growth (Fang et al. 2014). It's also important to note that the involvement of SOX2 in cell proliferation has been controversially discussed in colorectal and gastric cancer (Liu H et al. 2013).

SOX2 also plays an important role in evading apoptotic signals. In prostate cancer, in vitro and in vivo xenograft experiments using DU145 Sox2-overexpressing cells in NOD/SCID mice revealed that SOX2 caused an increase in apoptotic resistance by decreasing store-operated calcium entry (Jia et al. 2011). Equivalently, upon silencing of SOX2 in non-small cell lung carcinoma (NSCLC) cell lines, apoptosis was induced (Chen et al. 2013)

Research has indicated that SOX2 is a novel regulator of cell invasion, migration and metastasis. For example, in melanoma, SOX2 knockdown in A2058 cells resulted in a 4.5 fold decrease in invasion in vitro (Girouard et al. 2012). Likewise in colorectal cells, SOX2 was involved in cellular migration and invasion in vitro (Han et al. 2012). This invasive phenotype was also confirmed in malignant glioma, since siRNAmediated down regulation of SOX2 resulted in a significant decrease in migration and invasion capabilities (Alonso et al. 2011).

\section{5 $\underline{\text { Soft Tissue Tumors }}$}

\subsubsection{Epidemiology}

The incidence of soft tissue tumors, especially the frequency of benign tumors relative to malignant ones, is nearly impossible to determine accurately. Benign soft tissue tumors outnumber malignant tumors by a wide margin (Goldblum et al. 2014). However, according to an analysis of the Surveillance, Epidemiology and End Results (SEER) database, the incidence changes with age; for children younger than 10 years of age, the annual incidence was $0.9 / 100,000$ in children but rose to $18.2 / 100,000$ in adults 
over the age of 70 years. The most dramatic increases occurred at 30 and 70 years of age (Ferrari et al. 2011).

Soft tissue sarcomas are rare tumors, representing less than one percent of all malignant neoplasms (Katenkamp and Katenkamp 2009). Adult soft tissue tumors are not represented in the figures of the Robert Koch Institute reporting of 427000 individuals in Germany being diagnosed with cancer in 2006 (Bertz et al. 2010). Assuming that mesenchymal malignancies constitute about one-hundredth of all cancer diagnoses (Fletcher et al. 2006), an estimated number of 4500 Germans annually develop a sarcoma

\subsubsection{Classification}

Soft tissue tumors constitute a large and heterogeneous group of neoplasms (Fletcher et al. 2006). Traditionally, soft tissue sarcomas have been classified according to a histogenetic concept (e.g., fibrosarcoma as a tumor arising from fibroblasts, osteosarcoma as a tumor arising from osteoblasts, and so on). However morphologic, immunohistochemical and data from experimental animals suggest that most if not all sarcomas arise from primitive multipotential mesenchymal cells, which in the course of neoplastic transformation undergo differentiation in one or more lines (Mills et al. 1995).

The acceptance of this alternative scheme does not require a change in terminology: a liposarcoma remains as such but is now viewed not as a tumor arising from a lipoblast but as a tumor exhibiting lipoblastic differentiation (Fletcher et al. 2006).

\subsubsection{Pathogenesis}

The large majority of soft tissue sarcomas arise de novo rather than from malignant degeneration of preexisting benign tumors. Although the latter phenomenon may occur (as in neurofibromas), in most cases in which a given benign tumor is said to have become malignant, review of the original material showed that it was malignant from its inception (Laskin et al. 1988). 


\subsubsection{Environmental factors}

Trauma is frequently implicated in the development of sarcomas. Much has been written in the medical and legal literature on the possible relationship between trauma and soft tissue sarcoma, but no convincing evidence has been provided for a definite cause-effect relationship between the two (Monkman et al.1974). Rare soft tissue sarcomas have been reported as arising in scar tissue following surgical procedures or thermal or acid burns, at fracture sites, and in the vicinity of plastic or metal implants, usually after a latent period of several years (Piscitelli et al. 2011).

Worth noting is that trauma, whether etiologically related to a tumor or proven to be indulged in tumor-emergence by causing specific genetic alterations, should be regarded as more than just a random co-incidence. The emergence of mutations, for example, may be favored in the proliferative state that occurs within fibroblasts in the setting of a trauma (Petersen 2017).

Phenoxyacetic acid herbicides, chlorophenols and their contaminants such as 2 , 3, 7, 8-tetrachlorodibenzo-para-dioxin (dioxin) have been linked to sarcomagenesis (Zambon et al. 2007; Collins et al. 2009). A series of case-control studies from Sweden from 1979 to 1990 reported an up to six fold increased risk of soft tissue sarcoma associated with exposure to phenoxyacetic acids or chlorophenols in individuals exposed to these herbicides in agricultural or forestry work (Hardell et al. 1998). Similar reports of an increased risk of sarcoma associated with these herbicides were reported from Italy (Bertazzi et al. 2001), Great Britain and New Zealand.

The possibility of an increased incidence of sarcomas was claimed for some of the two million soldiers stationed in Vietnam between 1965 and 1970 who were exposed to Agent Orange, a defoliant that contained dioxin as a contaminant (Kramárová et al. 1998). Vinyl chloride exposure is clearly associated with the development of hepatic angiosarcoma (Sahmel et al. 2009; Sherman M et al. 2009).

Radiation exposure has been related to the development of sarcomas, but considering the frequency of radiotherapy, radiation-induced soft tissue sarcomas are quite uncommon. The incidence of post-radiation sarcoma is difficult to estimate, but 
reports generally range from $0.03 \%$ to $0.8 \%$ (Mark et al. 1996; Inoue et al. 2000). Nearly all post-radiation sarcomas occur in adults, and women develop these tumors more frequently, an observation which reflects the common use of radiation for the treatment of breast and gynecologic malignancies (Weaver et al. 2009).

Although the incidence of radiation associated angiosarcoma (RAAS) is low, the number of cases reported is increasing as a function of the improved likelihood of surviving early stage breast carcinoma. Furthermore, with increased use of external beam radiation in the management of breast cancer patients, the incidence of postradiation sarcomas may increase in the future. Long-term follow-up is needed for early disease detection (Torres et al. 2013).

Unfortunately most post radiation sarcomas are high-grade lesions and are detected at a relatively higher stage than their sporadic counterparts (Billings et al. 2004). Patients with radiation-induced sarcoma of the extremities have the best survival (approximately $30 \%$ at 5 years), whereas those with lesions arising in the vertebral column, pelvis and shoulder girdle generally have survival rates of less than $5 \%$ at 5 years (Fang et al. 2004).

\subsubsection{Oncogenic Viruses}

The role of oncogenic viruses in the evolution of soft tissue sarcomas is still poorly understood, although there is strong evidence that the human herpesvirus 8 (HV8) is the causative agent of Kaposi's sarcoma (Mesri et al. 2010). In addition, there is a large body of literature supporting the role of the Epstein-Barr virus in the pathogenesis of smooth muscle tumors in patients with immunodeficiency syndrome or following therapeutic immunosuppression in the transplant setting (Deyrup et al. 2006).

\subsubsection{Immunologic factors}

Acquired immunodeficiency, or loss of immune surveillance, may lay a central role in the development of the relatively rare angiosarcomas that arise in the setting of chronic lymphedema (Shon et al. 2011), secondary to radical mastectomy (StewartTreves syndrome) (Dawlatly et al. 2011) or congenital or infectious conditions (Roy et al. 2004). 


\subsubsection{Genetic factors}

A number of genetic diseases are associated with the development of soft tissue tumors, and the list will undoubtedly lengthen as we begin to understand the molecular underpinnings of mesenchymal neoplasia. Neurofibromatosis type 1, neurofibromatosis type 2 and familial adenomatous polyposis (FAP)/Gardner syndrome are classic examples of genetic diseases associated with soft tissue tumors (Goldblum et al. 2014)

\subsubsection{Clinical Features}

A definite relationship exists between soft tissue tumor type and the age of presentation (Rydholm et al. 1984). For instance, embryonal rhabdomyosarcoma is typically a tumor of infants and children, synovial sarcoma typically affects adolescents and young adults, liposarcomas and undifferentiated pleomorphic sarcomas are usually seen in middle-aged and elderly patients. It is interesting that congenital soft tissue tumors rarely behave in a malignant fashion (Kauffman et al. 1965).

Most soft tissue sarcomas are solitary. Synchronous or metachronous multiple sarcomas represent only $0.2 \%$ of all cases. Liposarcomas account for a high percentage of these cases (Grobmyer et al. 2004).

\subsubsection{Diagnosis}

Appropriate diagnoses are of great importance to the patient to obtain the adequate therapy. Since misdiagnoses are not uncommon, specialist centers provide valuable resources for the verification of suspected malignant mesenchymal tumors (Lehnhardt et al. 2009; Petersen et al. 2011).

For any large soft tissue tumor in which the possibility of malignancy exists, the proper initial diagnostic procedure is to obtain material through incisional biopsy or fine needle aspiration. The latter technique is being used with increased frequency in the United States, with rates of accuracy equivalent to those obtainable with frozen section (Layfield et al. 1986).

Light microscopic evaluation of hematoxylin-eosin-stained sections remains the standard technique for the initial diagnostic approach to these tumors and is sufficient in 
the majority of the cases (Enjoji et al. 1984). However, there are special techniques that have been successfully applied to increase diagnostic accuracy and which sometimes are indispensable, this development applying both to adult and pediatric tumors (Iwasaki et al. 2009). These techniques include conventional special stains, electron microscopy, immunohistochemistry and molecular genetic methods (Rosai and Ackerman 2011).

Immunohistochemistry for tissue-related markers has proved to be of great value and is now extensively used to accurately classify these neoplasms: the specificity, sensitivity and applicability of this technique to routinely processed material clearly render it the method of choice in most circumstances (Heim-Hall et al. 2008). The number of available markers is very large and continues to grow (Ordóñez et al. 1998).

The systemic use of cytogenetics has shown the existence of nonrandom chromosomal alterations (mainly translocations) in association with many types of soft tissue tumor (Sandberg AA et al. 2002).

Gene fusions have been described in approximately one-third of soft tissue tumors (STT); of the 142 different fusions that have been reported, more than half are recurrent in the same histologic subtype. These gene fusions constitute pivotal driver mutations, and detailed studies of their cellular effects have provided important knowledge about pathogenetic mechanisms in STT (Mertens et al. 2016).

The findings have validated the morphologic approach to classification of soft tissue tumors, helped to refine the boundaries of some entities and offered insight into the genesis of the tumors. Furthermore, the molecular alterations (gene fusions) that result from the chromosomal translocations can now be readily demonstrated in routine paraffin-embedded tissues by reverse transcriptase polymerase chain reaction (RT-PCR) or fluorescent in situ hybridization (FISH), and such studies can be extremely helpful in the diagnosis of these tumors especially in small biopsies, tumors with unusual morphology, or tumors in unusual sites (Antonescu et al. 2006).

As an example, a break-apart FISH probe against the EWS (also known as EWSR1) gene is particularly helpful since this gene is implicated in many different soft 
tissue tumor types, including Ewing sarcoma/PNET, angiomatoid fibrous histiocytoma, extraskeletal myxoid chondrosarcoma, myxoid liposarcoma, clear cell sarcoma of tendons and aponeurosis and desmoplastic small cell tumor (Chang et al. 2003).

\subsubsection{Grading and Staging}

Some degree of microscopic grading of soft tissue is already built into the conventional microscopic classification of these tumors. The number of grades has varied in the different systems: two (low-grade and high-grade), three (I, II and III or low-grade, intermediate-grade and high-grade) and four (I, II, III and IV) grades have been recognized (Deyrup et al. 2006).

The criteria used have included degree of cellularity, pleomorphism, mitotic activity and necrosis and have been found to be of definite prognostic value for both adult and pediatric soft tissue tumors (Coindre et al. 1988), however it is misleading to over-emphasize grading that is independent of the specific microscopic type of the sarcoma and the circumstances in which it occurs, such as the patient's age or the depth and size of the tumor (Deyrup et al. 2006).

The two grading schemes that have been most widely applied are those of the French Federation of Cancer Centers Sarcoma Groups and the National Cancer Institute (Coindre et al. 2001). The WHO meanwhile propagates the "Fédération Nationale des Centres de Lutte Contre le Cancer"; FNCLCC system (Fletcher et al. 2013)

French federation of Cancer Centers Sarcoma Group (Fédération Nationale des Centres de Lutte Contre le Cancer"; FNCLCC system) grading system 


\begin{tabular}{|l|l|}
\hline Tumor Differentiation \\
\hline Score 1 & $\begin{array}{l}\text { Sarcomas closely resembling normal adult mesenchymal tissue. } \\
\text { Examples: well-differentiated liposarcomas and well-differentiated } \\
\text { fibrosarcoma. }\end{array}$ \\
\hline Score 2 & $\begin{array}{l}\text { Sarcomas for which the histologic typing is certain. Examples: } \\
\text { biphasic synovial sarcoma, alveolar soft-part sarcoma, myxoid } \\
\text { liposarcoma }\end{array}$ \\
\hline Score 3 & $\begin{array}{l}\text { Embryonal sarcomas, undifferentiated sarcomas and sarcomas of } \\
\text { doubtful tumor type }\end{array}$ \\
\hline Mitosis count & $0-9$ mitoses per 10 high power fields \\
\hline Score 1 & $10-19$ mitoses per 10 high power fields \\
\hline Score 2 & More than 20 mitoses per 10 high power fields \\
\hline Score 3 & No necrosis on any examined slides \\
\hline Tumor necrosis & \\
\hline Score 0 & Less than $50 \%$ tumor necrosis for all the examined tumor surface \\
\hline Score 1 & Tumor necrosis on more than half of the examined tumor surface \\
\hline Score 2 &
\end{tabular}

The three grade system is set-up as follows: Grade I is defined as a total of 2 or 3 when summing the scores obtained for each of the three histologic criteria; grade II represents a total of 4 or 5; grade III represents a total of 6,7 or 8 .

Two main staging systems for soft tissue sarcoma have been proposed. The one exposed by the American Joint Committee (AJC) is largely based on the TNM system, in that it uses the size of the primary tumor $(\mathrm{T})$, the status of lymph nodes $(\mathrm{N})$, the presence of distant metastases (M), and the tumor's histological grade (G) (Behars et al. 1992).

\subsubsection{Prognosis}

Prognosis of soft tissue tumors depends on a variety of parameters, many of which are interrelated.

- Tumor size: there is a definite relationship between tumor size and outcome. This is true for practically all tumor types in which this parameter has been analyzed (Rooser et al. 1988).

- Depth: Superficially located tumors (dermis and subcutaneous tissue) have a much better prognosis than deep-seated ones (intermuscular or intramuscular, 
retroperitoneal) of similar microscopic type (Gerrand et al. 2003). Along similar lines, soft tissue sarcomas featuring histologic evidence of bone invasion have a poorer prognosis (Ferguson et al. 2006).

- Location: Tumors of the retroperitoneum do much worse than microscopically similar lesions located in the extremities. Among the latter, local recurrence has been found to be more frequent with sarcomas of the upper extremity than those of the lower extremity (Gerrand et al. 2003).

- Microscopic type: Some soft tissue neoplasms (such as atypical lipomatous tumors) are low-grade lesions with no capacity to metastasize, whereas other neoplasms of similar cell type (such as pleomorphic liposarcoma) are highly aggressive and prone to spread distantly (Rosai and Ackerman 2011).

- Vascular invasion: This has been shown to be the strongest predictor of distant metastases in several series (Engellau et al. 2005).

- Surgical margins: Not surprisingly, adequacy of surgical margins is statistically associated with low relapse (Stojadinovic et al. 2002).

- Microscopic grade: A relationship has been found between various microscopic grading systems and outcome, which in some cases is directly related to the histotype but in others it is applied within a given histotype (Rosai and Ackerman 2011).

- Clinical stage: this determination, which incorporates several of the previously mentioned parameters, as well as the presence or absence of metastases, is the most powerful prognostic determinator (Rosai J and Ackerman LV. 2011).

- DNA ploidy: Several flow cytometric studies performed in soft tissue sarcomas of various microscopic types have shown that DNA ploidy correlates with a higher microscopic grade, a higher rate of cell proliferation and decreased survival rates (Kroese MC et al. 1990).

- Cell proliferation: Mitotic activity is incorporated in most grading schemes. Evaluation of proliferation markers such as MIB-1 and p105 has been shown to correlate with prognosis (Hasegawa et al. 2007)

- Genetic alterations: It has been shown that soft tissue tumors exhibiting mutations of TP53 or altered expression of retinoblastoma gene behave more aggressively than those lacking these changes (Kawai A et al. 1994). Claims have been made of a 
relationship between the type of gene fusion in the sarcomas associated with chromosomal translocations and prognosis (as in alveolar rhabdomyosarcoma and synovial sarcoma) (Rosai and Ackerman 2011).

\subsection{Synovial Sarcoma}

Synovial sarcoma is a rare and aggressive soft tissue tumor that accounts for approximately $10 \%$ of soft tissue sarcomas and classically occurs in the extremities of young adults (Amary et al. 2007; Terry et al. 2007). It occurs at any age but the peak incidence is between the ages of 10 and 35 years; with a slight male predominance. The anatomic distribution is wide, but more than $60 \%$ arise in the lower limb (Bergh et al. 1999). A small but significant proportion of cases arise on the trunk, especially in the abdominal wall (Fetsch et al. 1993) in the neck (Roth et al. 1975), in the head (Shmookler et al. 1982), in the mediastinum (Suster et al. 2005) and even in the abdominal cavity (Fisher et al. 2004).

Overall 5-year survival probability is about $60-65 \%$ but falls to only around $30 \%$ at 10 years. In general, small tumor size $(<5 \mathrm{~cm})$, early clinical stage, early age at presentation ( $<10$ years) and lower histologic grade (as defined by mitotic activity and necrosis) are signs of a better prognosis (Lewis et al, 2000).

Synovial sarcoma falls into two main groups, monophasic composed entirely of spindle cells and biphasic showing both epithelial and spindle cell components. The monophasic variant is more common, depending on sampling (Fletcher et al. 2002). Approximately $5-10 \%$ of cases have a poorly differentiated appearance, most often characterized by undifferentiated round cell morphology. These appear to be relatively more frequent in elderly patients with synovial sarcoma (Chan et al. 2003).

Immunohistochemically, in addition to positive staining in the obviously epithelial component, in almost all cases the spindle cell element also shows at least focal positivity for epithelial membrane antigen (EMA) and keratin; this, combined with morphologic clues, is generally the best way to distinguish monophasic lesions from malignant peripheral nerve sheath tumor (MPNST) or fibrosarcoma (Pelmus M et al. 
2002). Around $30 \%$ of cases of synovial sarcoma are S-100 protein positive, similarly at least two thirds of synovial sarcomas stain positively for CD99 (Pelmus et al. 2002).

Cytogenetically, both biphasic and monophasic forms (as well as poorlydifferentiated lesions) share a reproducible tumor-specific chromosome translocation, $\mathrm{t}(\mathrm{X} ; 18)(\mathrm{p} 11.2 ; \mathrm{q} 11.2)$, which results in the production of one or other of two prinipal fusion genes, SYT-SSX1 and SYT-SSX2 (Sanberg et al. 2002).

\subsection{BAF (Brg/Brahama-associated factors) complex and genetic} $\underline{\text { mutations }}$

Studies over the years involving drugs such as histone deacetylase and histone methyl transferase inhibitors, hydroxamic acid, sirtuins and others have suggested the important role of epigenetic modulation in cancer-indeed, nearly all cancers display epigenetic changes, and most cancer mutations, in either a direct or indirect manner, affect the epigenome (Dawson et al. 2012).

Among the most frequent mutations uncovered in human cancer sequencing efforts were mutations in genes encoding the subunits of adenosine triphosphate (ATP)dependent chromatin remodeling complexes, most notably the mammalian SWI/SNF or $\mathrm{BAF}(\mathrm{Brg} /$ Brahma-associated factors) complexes (Kadoch et al. 2013). Evidence indicating that polycomb complexes are an important primary target of mammalian $\mathrm{SWI} / \mathrm{SNF}$ or BAF complexes has emerged in more recent years from the observation that mutation of the ATPase Brgl of BAF complexes leads to H3K27Me3 accumulation and repression of many genes in embryonic stem (ES) cells (Ho et al. 2011).

The advent of exome sequencing across a diverse range of human cancers has led to the realization that BAF complexes are one of the most significant tumor suppressors in humans, with a cumulative incidence of mutation of more than $20 \%$ of human cancers sequenced to date (Kadoch et al. 2013). Many cancers (if not most) bearing BAF subunit mutations have a mutation in only one allele of the affected subunit, making them dominant tumor suppressors, rather than recessive (Kadoch et al. 2013). 
The most commonly affected BAF subunit in cancer is ARID1A (BAF250A) which has been found to be mutated in a variety of tumors including endometrial, colon and rectal carcinomas (Kandoth et al. 2013). BAF 170 is mutated in gastric and colorectal cancers with microsatellite instability. The homologous subunit of BAF155 is mutated in about $10 \%$ of small cell lung cancers (Kadoch C et al. 2013).

In certain tumors, specific genes are mutated in $100 \%$ of the cancers in $100 \%$ of the cells, which provides definitive evidence that these mutations cause the development and maintenance of the tumor. An example is human synovial sarcoma which has provided ground for the discovery of a mechanism underpinning perturbation to the SS18 subnuit of BAF complexes by the $\mathrm{t}(\mathrm{X} ; 18)$ translocation hallmark to human synovial sarcoma (Naka et al. 2010).

The $\mathrm{t}(\mathrm{X} ; 18)$ chromosomal translocation, as illustrated in synovial sarcoma, results in the direct fusion of 78 amino acids of C-terminus of SSX to the SS18 terminus giving a fusion protein that evicts wild-type SS18 and causes displacement of BAF47. The SSX-SS18 containing complexes are then retargeted to oncogenic loci such as SOX2 and PAX6, activating these genes by displacement of PRC2 complexes and their H3K27me3 repressive marks (Kadoch and Crabtree 2013).

This oncogenic eviction of polycomb can be reversed by stoichiometrically altering the balance of SS18-SSX versus wild-type SS18 within BAF complexes thereby reversing the complex to an induced wild-type bearing normal subunit composition and hence an exciting therapeutic opportunity emerges from these findings (Kadoch and Crabtree 2013). 


\section{AIM OF WORK}

The transcription factor SOX2 was proved to be amplified in different types of tumors including small cell lung cancer and many other forms of carcinomas, the aim of our study is to examine SOX2 expression in synovial sarcoma and compare the expression in this specific soft tissue tumor to other soft tissue tumor entitites including fibrosarcoma, rhabdomyosarcoma, liposarcoma and undifferentiated pleomorphic sarcoma.

We are also interested in testing and trying to analyze the Sox 2 gene status, in positive cases, through further fluorescence in situ hybridization technique.

Our study also aims to further investigate a SOX2- H3K27me3 relationship if present.

The study attained an approval from the ethics committee of Friedrich-Schiller University of Jena, Faculty of medicine; approval number 5318-10/17. 


\section{Publication Original Work}

Pathology - Research and Practice 214 (2018) 1000-1007

Contents lists available at ScienceDirect

Pathology - Research and Practice

journal homepage: www.elsevier.com/locate/prp

\section{Stem cell transcription factor SOX2 in synovial sarcoma and other soft tissue tumors}

Heba Zayed ${ }^{\mathrm{a}, \mathrm{b}}$, Iver Petersen ${ }^{\mathrm{a}, \mathrm{w}}$

a Institute of Pathology, Jena University Hospital, Germany

${ }^{\mathrm{b}}$ National Cancer Institute, Cairo University, Egypt

\section{A R T I C L E I N F O}

\section{Keywords:}

SOX2

H3K27me3

Synovial sarcoma

Soft tissue tumors

\section{A B S T R A C T}

Background: SOX2 has gained considerable interest as a pluripotency inducing gene. Co-transfection of SOX2 together with NANOG, KLF4 and c-MYC into adult fibroblasts was able to generate pluripotent stem cells. SOX2 has been reported to be expressed in synovial sarcoma, a tumor being characterized by the SS18-SSX gene fusion forming part of the SWI/SNF chromatin remodeling complex that affects histone methylation. The role of SOX2 in this tumor type as well as other soft tissue tumor entities however is still poorly characterized. We analyzed SOX2 protein expression in soft tissue tumors. Alongside we tested Histone H3 expression (H3K27me3) in SOX2 positive cases to investigate this epigenetic mark and its correlation with the SOX2 status and clinicopathological parameters.

Methodology: In total, 60 samples of synovial sarcomas from the reference center for soft tissue tumors at the institute of pathology of the Jena University hospital were included into the study along with 343 other tissue tumors. Protein analysis was done by immunohistochemistry of tissue microarrays. All synovial sarcoma cases were confirmed by molecular testing using SS18 FISH break apart probes.

Results: SOX2 reactivity was detectable in 35 synovial sarcoma cases (58.3\%) while $25(41.7 \%)$ were negative. Only 13 cases of the other 343 soft tissue tumors, varying from nodular fasciitis to undifferentiated pleomorphic sarcoma, revealed a SOX2 expression, 12 out of these were undifferentiated high grade sarcoma. There was no obvious correlation with the clinicopathological data. H3K27me3 immunohistochemistry of the synovial sarcoma cases revealed a high statistically significant correlation between SOX2 and H3K27me3 expression ( $p<0,0005$, Chi square test). Similar to SOX2, there was no correlation between H3K27me3 expression and tumor grade. Six SOX2 positive synovial sarcoma cases were analyzed by FISH using a SOX2/CEN3 dual color FISH probe. None of these cases revealed an amplification of the SOX2 gene.

Conclusion: The data confirms previous studies reporting SOX2 and H3K27me3 expression in synovial sarcom and reveals that both biomarkers are related to each other. It strengthens the notion that the tumor type is driven by epigenetic processes similar to those that are operating in pluripotent stem cells. The relevance of these parameters in the pathway pathology of synovial sarcoma, i.e. the timing and dosing of SOX2 and H3K27me3 expression initiated by the SS18-SSX driver mutation together with the interplay of these events with other signaling pathways, cellular mechanisms and additional mutations in tumor progression, will require further studies

\section{Introduction}

\subsection{Soft tissue tumors and synovial sarcoma}

Soft tissue tumors constitute a large and heterogeneous group of neoplasms [1]. Traditionally, soft tissue sarcomas have been classified according to a histogenic concept (e.g., fibrosarcoma as a tumor arising from fibroblasts, osteosarcoma as a tumor arising from osteoblasts, and so on). However morphologic, immunohistochemical and data from experimental animals suggest that most if not all sarcomas arise from primitive pluripotent mesenchymal cells, which in the course of neoplastic transformation undergo differentiation in one or more lines [2]. Correct diagnosis is of great importance to the patient to obtain the adequate therapy. Since misdiagnoses are not uncommon, specialist centers provide valuable resources for the verification of suspected malignant mesenchymal tumors $[3,4]$.

Synovial sarcoma is a rare and aggressive soft tissue tumor that accounts for approximately $10 \%$ of soft tissue sarcomas and classically 
occurs in the extremities of young adults [5,6]. It occurs at any age but the peak incidence is between the ages of 10 and 35 years; with a sligh male predominance. The anatomic distribution is wide, but more than $60 \%$ arise in the lower limb [7]. A small but significant proportion of cases arise on the trunk, especially in the abdominal wall [8], in the neck [9] in the head [10], in the mediastinum [11] and even in the abdominal cavity [12]. In addition, many other localization have been reported, the largest cohort in this regard has been reported by our group [13].

Overall 5-year survival probability is about $60-65 \%$ but falls to only around $30 \%$ at 10 years. In general, small tumor size $(<5 \mathrm{~cm})$, early clinical stage, early age at presentation $(<10$ years) and lower histologic grade (as defined by mitotic activity and necrosis) are signs of a better prognosis [14]. Synovial sarcoma falls into two main groups, monophasic composed entirely of spindle cells and biphasic showing both epithelial and spindle cell components. The monophasic variant is more common [1]. Approximately $5-10 \%$ of cases have a poorly differentiated appearance, most often characterized by undifferentiated round cell morphology. These appear to be relatively more frequent in elderly patients with synovial sarcoma [15]

Immunohistochemically, in addition to positive staining in obvious epithelial components, in almost all cases the spindle cell element also shows at least focal positivity for epithelial membrane antigen (EMA) and keratin; this, combined with morphological clues, is generally the best way to distinguish monophasic lesions from malignant periphera nerve sheath tumor (MPNST) or fibrosarcoma. Around 30\% of cases of synovial sarcoma are $\$ 100$ protein positive, similarly at least two thirds of synovial sarcomas stain positively for CD99 [16].

Cytogenetically, both biphasic and monophasic forms as well as poorly-differentiated tumors share a reproducible tumor-specific chromosome translocation, $\mathrm{t}(\mathrm{X} ; 18)(\mathrm{p} 11.2 ; \mathrm{q} 11.2)$. This translocation creates an in-frame fusion and the production of one or the other of two principal fusion genes, SYT-SSX1 and SYT-SSX2 [17,18]. The abbreviation of the SYT gene was later changed to SS18. The translocation and gene fusion is demonstrable in virtually all synovial sarcoma case but not found in any other human neoplasms. Whereas SS18, through its interactions with the SWI/SNF complex, might be expected to have a role in transcriptional activation, its fusion partner SSX associates with the polycomb repressor complex, which has opposing effects. An early observation was that SS18-SSX localizes at discrete nuclear foci within BMIl-labeled polycomb bodies [19]. More recently chromatin im munoprecipitation sequencing (ChIPSeq) results from HA-FLAG-tagged SS18-SSX, expressed in transfected C2C12 mouse myoblasts [20], correlated SS18-SSX binding with polycomb-marked nucleosomes (trimethylated histone H3K27) at a subset of genomic H3K27me3 sites.

\subsection{Stem cells, induced pluripotent stem cells and SOX2}

While cancer is defined by DNA mutations, differentiation and de velopment of normal cells and tissues are governed by epigenetic modifications. In 2006, Shinya Yamanaka was the first to successfully reprogram cells using four distinct factors, thereby generating induced pluripotent stem cells (iPSCs) from terminally differentiated fibroblasts. IPSCs can be established by the over-expression of four key transcription factors, OSKM: Oct4, SOX2, Klf4 and c-Myc [21]. One of the majo advantages of iPSCs is that they can be made autologously and can provide a sufficient quantity of cells by culturing, making the use of other stem cell sources unnecessary [22]. It has been demonstrated that reprogramming factor expression results in dysplasia and tumor formation in vivo, thus suggesting that OSKM has an impact on epigenetic changes that are substantially involved in the regulation of cell growth and tumorigenesis [23]. This observation is corroborated by the fact that pluripotent embryonic stem cells form teratomas upon implantation in vivo [24]. Of note, human iPSCs develop teratomas more efficiently and faster than human embryonic stem cells [25].

SRY (sex determining region Y)-box2, also known as SOX2 and being located on chromosome $3 q 26.33$, is a transcription factor that is essential for maintaining self-renewal or pluripotency of undifferentiated embryonic stem cells and plays a critical role in maintenance of embryonic and neural stem cells $[26,27]$. SOX2 amplification has been found in several cancer types including glioblastoma, small-cell lung cancer (SCLC) and many forms of squamous cell carcinoma [28-30]. SOX2 has been shown to promote cellular proliferation in breast, prostate, pancreatic, cervical cancers as well as synovial sarcoma [31,32], evade apoptotic signals in prostate, gastric cancer and non-small cell lung carcinoma and promote invasion, migration and metastases in melanoma, colorectal glioma, gastric, ovarian cancer and hepatocellular carcinoma [33,34].

The aim of the present study was to evaluate the status of SOX2 in soft tissue tumors and in particular synovial sarcoma given the fact that expression has been observed in this entity $[32,35]$.

\section{Materials and methods}

\subsection{Tumor samples}

Tissue samples of all synovial sarcoma cases between January 2013 and December 2015 were selected. Both internal patients of FriedrichSchiller University hospital of Jena, as well as referred cases to the Institute of Pathology from other hospitals or pathology institutes were included. The Institute of Pathology of the University hospital of Jena became a national consultation and reference center after the German reunification in 1989. Not only German but also Austrian pathology institutes submit difficult cases to confirm previous diagnoses or to evaluate the suspicion of a soft tissue tumor, STT [4].

All the specimens $(n=60)$, excluding some referred cases whose histopathological material was not anymore available in the institute $(n=6)$ and cases $(n=4)$ whose paraffin block was not optimal for appropriate further material retrieval, were employed in this study. The clinicopathological analysis was conducted by highly specialized soft tissue tumors expert pathologists in the referral center. Immunohistochemical analysis was performed according to standard procedures to confirm the diagnosis (EMA, Bcl2, PanCK, CK7, CD34, Ki67 and S100). Molecular confirmation was performed by FISH to confirm the $\mathrm{t}(\mathrm{X} ; 18)$ translocation (Fig. 1).

Tissue Microarrays (TMA) of variable soft tissue tumors were also prepared in the institute and employed in this study [36]. For the construction of these, a morphologically representative region of the "donor"-paraffin blocks with soft tissue tumor was selected. From this representative region two core biopsies (diameter, $0.6 \mathrm{~mm}$; height 3-4 mm) from the invading front were taken and arrayed into a new "recipient" paraffin block using a custom-built instrument [37]. After the block production was finished, $4.0-\mu \mathrm{m}$ sections of the resulting tumor TMA block were cut for further analysis as recently described [36]. Tissue microarrays constructed included 343 soft tissue tumors (Table 2).

\subsection{Immunohistochemistry}

SOX2 and Histone HEK27me3 immunohistochemical staining was performed according to standard procedures using monoclonal antibodies (Anti-Human SOX2 Monoclonal Antibody, 1:100, clone SP76, Zytomed Systems; H3K27me3 antibody, mAbcam 6002, 1:200) and the recommendations of the manufacturer. SOX2 immunohistochemistry was evaluated in two cores per tumor. The average percentage was taken for statistical analysis.

Extranuclear SOX2 staining was regarded to be negative or unspecific. Staining intensity (SI) was assessed to be negative ( - ), weak $(1+)$, moderate $(2+)$ or strong staining $(3+)$. Reactivity $(R)$ was determined by the percentage of positive tumor cells (PP) and scored as follows: negative (0), 1-10\% positive cells (1), 11-30\% (2), 31-50\% (3), $51-80 \%$ (4) and $>80 \%$ positive cells (5). Intense/Reactivity score 

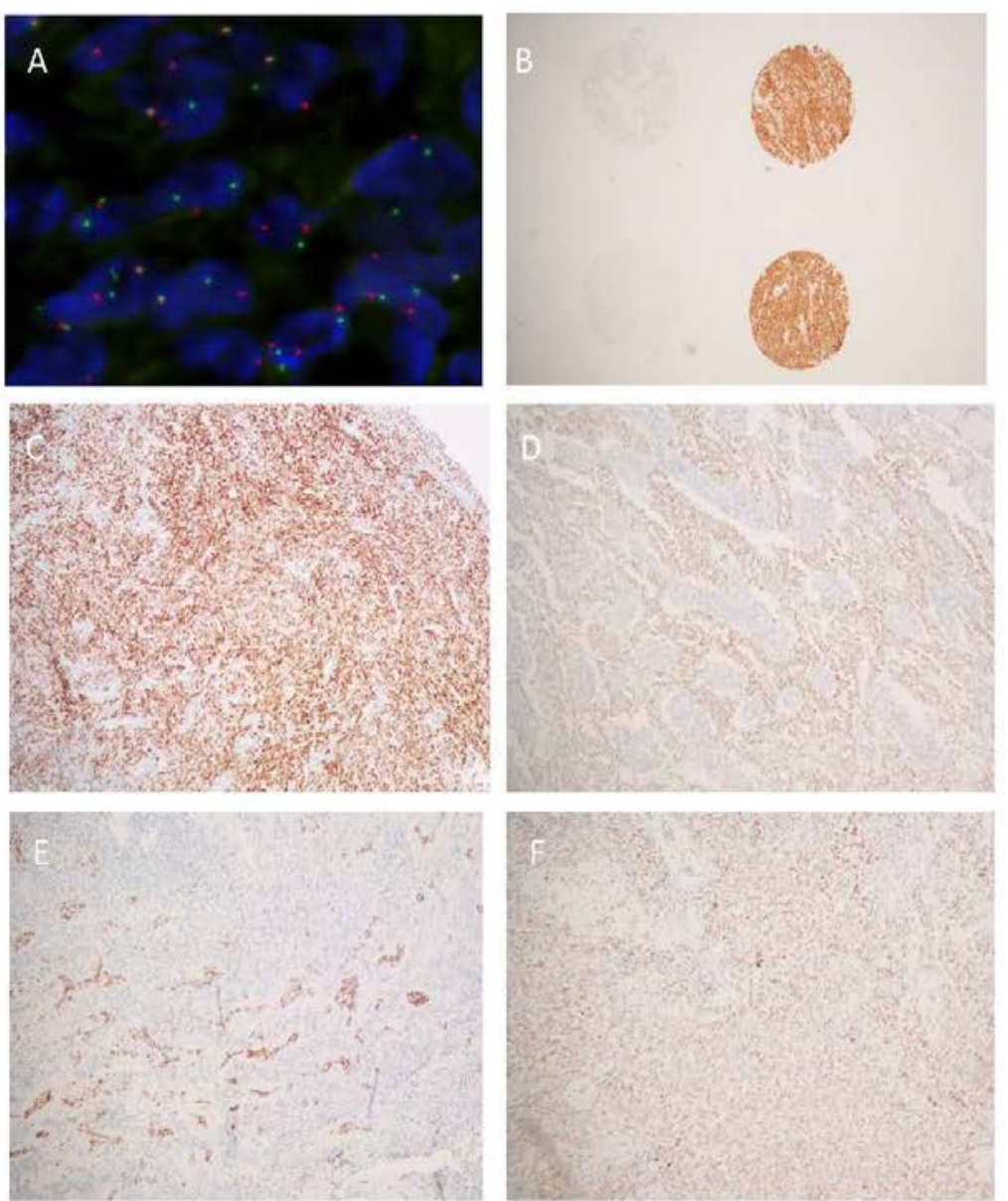

Fig. 1. SOX2 and $\mathrm{H} 3 \mathrm{~K} 27 \mathrm{me} 3$ in soft tissue tumors.

A - SS18 FISH analysis of a synovial sarcoma illustrating split red and green signals in $82 \%$ of cells indicative for a t(X:18) translocation. B - Tissue microarray with one negative (left) and one positive (right) - SOX2 high grade pleomorphic sarcoma. C - Synovial sarcoma showing strong Sox2 expression ( $3+$ ). D - Synovial sarcoma showing moderate SOX2 expression (2+). E- Synovial sarcoma showing weak SOX2 expression $(1+)$. F- Histone H3K27me 3 expression in a SOX2-positive synovial sarcoma.

(IRS) was calculated by multiplying PP with SI (minimum $0 /$ maximum 15). High expression was defined as $\geq 8$ according to the median IRS of positive stained cells.

SOX2 positive cases were further investigated for Anti-Histone H3 reactivity (H3K27me3 antibody, mAbcam 6002, 1:200). This was scored semi quantitatively as - negative; $1+$ weak; $2+$ moderate; $3+$ strong positive.

\subsection{Molecular confirmation of synovial sarcoma and SOX2-positive synovial sarcoma cases}

The $t(\mathrm{X} ; 18)$ translocation hallmark of synovial sarcoma was verified by dual color fluorescence in situ hybridization (dc FISH). For this, either interphase nuclei were isolated from paraffin-embedded tumor tissue and prepared as described or tissue sections were used [38,13]. The dcFISH was performed using SPEC SS18 (18q11.2) Dual Color Break Apart Probe (Zytovision, Germany) applying the protocol provided by manufacturer. Fifty nuclei were analyzed for chromosomal rearrangements of the SYT gene region located on chromosome 18 using a laser scanning microscope LSM510 (Zeiss, Jena, Germany).
DcFISH was assessed positive if at least $10 \%$ of the nuclei showed a translocation specific hybridization pattern [39].

SOX2 amplification was examined in some SOX2 positive synovial sarcoma cases, using SPEC SOX2/CEN3 Dual color Probe (Zytovision, Germany) following the protocol of the manufacturer.

\subsection{Statistical methods}

Data management and statistical analysis were performed using the Statistical Package for Social Sciences (SPSS) version 21. Numerical data were summarized using means and standard deviations or medians and ranges. Categorical data were summarized as percentages. Comparisons between the 2 groups with respect to normally distributed numeric variables were done using the $t$-test. For categorical variables, differences were analyzed with $\chi^{2}$ (chi square) test and Fisher's exact test when appropriate. All $p$-values are two-sided. P-values $<0.05$ were considered significant. 
Table 1

SOX2 expression in synovial sarcoma.

\begin{tabular}{|c|c|c|c|c|c|c|}
\hline & \multicolumn{5}{|l|}{ sox2 } & \multirow[t]{3}{*}{ P valur } \\
\hline & & \multicolumn{2}{|c|}{ Negative $(\mathrm{n}=25)$} & \multicolumn{2}{|c|}{ Positive $(\mathrm{n}=35)$} & \\
\hline & & No. & $\%$ & No. & $\%$ & \\
\hline Age (yrs.) & Mean \pm SD & \multicolumn{2}{|c|}{$46.1 \pm 11.0$} & \multicolumn{2}{|c|}{$38.9 \pm 18.5$} & 0.066 \\
\hline \multirow[t]{2}{*}{ Gender } & Female & 14 & 46.7 & 16 & 53.3 & \multirow[t]{2}{*}{0.432} \\
\hline & Male & 11 & 36.7 & 19 & 63.3 & \\
\hline \multirow[t]{3}{*}{ Grade } & I & 0 & 0.0 & 2 & 100.0 & \multirow[t]{3}{*}{0.465} \\
\hline & II & 19 & 44.2 & 25 & 55.8 & \\
\hline & III & 6 & 42.9 & 8 & 57.1 & \\
\hline \multirow[t]{2}{*}{ Site } & Extremities & 13 & 39.4 & 20 & 60.6 & \multirow[t]{2}{*}{0.693} \\
\hline & Others & 12 & 44.4 & 15 & 55.6 & \\
\hline \multirow[t]{2}{*}{ Ki67 } & Low Activity & 16 & 44.4 & 20 & 55.6 & \multirow[t]{2}{*}{0.593} \\
\hline & Moderate-High & 9 & 37.5 & 15 & 62.5 & \\
\hline Translocation (\%) & Mean \pm SD & 73.7 & & 77.9 & & 0.388 \\
\hline
\end{tabular}

\section{Results}

\subsection{Immunohistochemistry}

Expression of SOX2 was investigated in 60 synovial sarcoma cases of which 2 where grade 1,44 grade 2 and 14 grade 3 . The SOX 2 reactivity was positive in 35 cases (58.3\%) and negative in 25 (41.7\%). The SOX2 status (positive versus negative) as well as the percentage of positive cells revealed no significant correlations with clinicopathological parameters. Examples of the immunohistochemical assessment of SOX2 staining in synovial sarcoma are shown in Fig. 1. The results are summarized in Table 1 . All grade 1 cases were positive (2/2), $57 \%$ of grade 2 were positive (25/44) and $57 \%$ of grade 3 as well were positive ( $8 /$ 14). The proliferative activity of the synovial sarcoma tumors, portrayed through Ki67 activity, indicated that $56 \%$ of the tumors exhibiting low proliferative activity were SOX2 positive (20/36) while $63 \%$ of the tumors with moderate to high proliferation revealed SOX2 positivity $(15 / 24)$

In addition, 343 soft tissue tumors, varying from nodular fasciitis to

Table 2

SOX2 expression in other soft tissue tumor types (non-synovial sarcoma).

\begin{tabular}{|c|c|c|c|c|}
\hline \multirow[t]{3}{*}{ Diagnose } & \multicolumn{4}{|l|}{ sox2 } \\
\hline & \multicolumn{2}{|l|}{ Negative } & \multicolumn{2}{|l|}{ Positive } \\
\hline & Number & $\%$ & Number & $\%$ \\
\hline Adult fibrosarcoma & 1 & 0.3 & 0 & 0.0 \\
\hline Alveolar rhabdomyosarcoma & 1 & 0.3 & 0 & 0.0 \\
\hline Alveolar soft part sarcoma & 3 & 0.9 & 0 & 0.0 \\
\hline Dedifferentiated liposarcoma & 3 & 0.9 & 0 & 0.0 \\
\hline Endometrial stromal sarcoma, low grade & 2 & 0.6 & 0 & 0.0 \\
\hline Epithelioid sarcoma & 2 & 0.6 & 0 & 0.0 \\
\hline Extraskeletal myxoid chondrosarcoma & 1 & 0.3 & 0 & 0.0 \\
\hline Inflammatory myofibroblastic tumour & 1 & 0.3 & 1 & 7.7 \\
\hline Ischaemic fascilitis & 3 & 0.9 & 0 & 0.0 \\
\hline Low grade fibromyxoid sarcoma & 10 & 3.0 & 0 & 0.0 \\
\hline Low grade myofibroblastic sarcoma & 32 & 9.7 & 0 & 0.0 \\
\hline MPNST & 1 & 0.3 & 0 & 0.0 \\
\hline Myositis ossificans & 4 & 1.2 & 0 & 0.0 \\
\hline Myxoinflammatory fibroblastic sarcoma & 3 & 0.9 & 0 & 0.0 \\
\hline Nodular fasciitis & 66 & 20.0 & 0 & 0.0 \\
\hline Proliferative fasciitis & 9 & 2.7 & 0 & 0.0 \\
\hline $\begin{array}{l}\text { Undifferentiated high grade pleomorphic } \\
\text { sarcoma }\end{array}$ & 179 & 54.2 & 11 & 84.6 \\
\hline $\begin{array}{l}\text { Undifferentiated pleomorphic sarcoma with } \\
\text { giant cells }\end{array}$ & 7 & 2.1 & 1 & 7.7 \\
\hline $\begin{array}{l}\text { Undifferentiated pleomorphic sarcoma with } \\
\text { prominent inflammation }\end{array}$ & 2 & 0.6 & 0 & 0.0 \\
\hline Non-synovial sarcoma soft tissue tumors & \multicolumn{2}{|c|}{$330(96.2 \%)$} & \multicolumn{2}{|l|}{$13(3.8 \%)$} \\
\hline
\end{tabular}

undifferentiated pleomorphic sarcoma, were analyzed in this study and revealed minimal SOX2 expression. Only 13 cases ( $3.8 \%)$ were positive, $12(92.3 \%)$ out of these were undifferentiated high grade sarcoma (Table 2). The twelve patients of undifferentiated high grade pleomorphic sarcoma ranged in age from 29 to 79 years with female predominance (females $=8$, males $=4$ ). Analyzing the clinical data, there were no obvious correlations with clinicopathological data: 6 cases were from the lower extremity, 4 from the trunk, 1 form the head and neck region (occipital) and 1 other tumor was located in the skin. Still, it is interesting that all SOX2 positive tumors were high grade sarcomas.

The positive and negative synovial sarcoma cases were further subjected to Anti-Histone H3K27me3 immunohistochemistry. The expression data was related to the SOX2 reactivity as illustrated in Table 3 . The statistical analysis revealed a high statistically significan correlation between SOX2 and H3K27me3 expression ( $\mathrm{p}<0.0005$, Chi square test). Out of 35 SOX2 positive synovial sarcoma cases, 25 $(71,4 \%)$ were $\mathrm{H} 3 \mathrm{~K} 27 \mathrm{me} 3$ positive and $10(28,6 \%)$ were negative. Concurrently, out of 25 SOX2 negative cases, only $3(12 \%)$ were H3K27me3 positive and $22(88 \%)$ were negative. Similar to SOX2, there was no correlation between $\mathrm{H} 3 \mathrm{~K} 27 \mathrm{me} 3$ expression and tumor grade in synovial sarcoma. An example of the immunohistochemical assessment of Histone (H3K27me3) in a SOX2-positive synovial sarcoma is shown in Fig. 1.

\subsection{FISH analysis of synovial sarcoma cases}

Fluorescence in situ hybridization (FISH) detection of $t(X ; 18)$ translocation of synovial sarcoma was carried out in all the 60 cases. Al samples showed a split apart signal using a SS18/SYT dual color probe (Fig. 1). The percentage of positive cells varied from $44 \%$ to $96 \%$. Of the immunohistochemically SOX2 positive synovial sarcoma cases, six were randomly selected and analyzed by FISH using a SOX2/CEN3 dual color FISH probe. None of these cases, revealed an amplification of the sOX2 gene.

Table 3

Histone H3K27me3 expression in correlation with SOX2 reactivity in synovial sarcomas.

\begin{tabular}{llllll}
\hline & & & \multicolumn{2}{l}{ SoX2 } & \multirow{2}{*}{ Total } \\
\cline { 3 - 4 } & & & Negative & Positive & \\
\hline \multirow{2}{*}{ H3K27me3 } & \multirow{2}{*}{ Negative } & Count & 22 & 10 & 32 \\
& & \% of Total & $36.7 \%$ & $16.7 \%$ & $53.3 \%$ \\
& Positive & Count & 3 & 25 & 28 \\
& & \% of Total & $5.0 \%$ & $41.7 \%$ & $46.7 \%$ \\
Total & & Count & 25 & 35 & 60 \\
& & \% of Total & $41.7 \%$ & $58.3 \%$ & $100.0 \%$ \\
\hline
\end{tabular}




\section{Discussion}

\subsection{Role of SOX2 in synovial sarcoma and other cancer types}

Synovial sarcoma is classified as a soft tissue tumor of uncertain cellular origin [1]. It may be derived from primitive mesenchymal cells that can undergo differentiation and has been characterized as a stem cell malignancy $[40,41]$. In the last decades, a major change has taken place in cancer biology in emphasizing the importance of cancer stem cells and their relationship to embryonic stem (ES) cells whose biology is governed by stem cell transcription factors like SOX2. Embryonic stem cells proliferate without apparent limit, they can readily be propagated clonally and are not subject to contact inhibition or anchorage dependence. These are typical features of transformed cells and, indeed, ES cells are tumorigenic. Thus ES cells can be considered as conditional tumor cells [42]. The accumulated understanding of the mechanisms underlying pluripotency in ES cells led to attempts to revert somatic cells into a pluripotent state using the Oct $3 / 4$, SOX 2 , Klf 4 and c-Myc reprogramming factors. SOX2 is an essential transcription factor, which not only has a role during neurogenesis and embryonic foregut development, but also allows reprogramming of adult cells to pluripotent stem cells [43]. Evidence has recently been accumulating to support the hypothesis that solid tumors contain a small subpopulation of cell called cancer stem-like cells, which exhibit self-renewing capacities and are responsible for tumor maintenance and metastases [44]. SOX2 has been suggested as a marker for cancer stem cells in various tumor types $[45,30]$.

The objective in our study was (1) to examine SOX2 expression in synovial sarcoma, (2) to compare the expression in synovial sarcoma to that in other soft tissue tumors and (3) to analyze mechanisms with impact on SOX2 expression like SOX2 gene status and H3K27me3 expression in synovial sarcoma. The study was carried out on 60 cases of synovial sarcoma and 343 cases of different other soft tissue tumors that were referred to the Jena consultation and reference center of soft tissue tumors. A wide panel of biomarkers was used to analyze and confirm the diagnosis of all included soft tissue tumors. Standard, full-sized tissue sections were used to construct tissue microarrays (TMAs) for analyzing SOX2 and other biomarkers.

About $60 \%$ of all synovial sarcoma cases were positive to SOX2. Al grade 1 cases were positive $(2 / 2)$ while less than $60 \%$ of grade 2 and grade 3 cases revealed SOX2 expression. Similarly, there was only minor difference of SOX2 positivity in the low proliferative group (56\%) versus moderately to highly proliferating tumors $(63 \%)$ Together with the fact that the majority of undifferentiated sarcomas were SOX2 negative, this suggests that SOX2 does not seem to be essential for tumor progression, but may play an essential role in tumor initiation.

The relationship between SOX2 expression and tumor behavior is highly controversial. It is intriguing that some studies reported bette tumor behavior with SOX2 expression. Züllig and colleagues were able to study the process of early lymphatic metastases in squamous cell carcinoma (SCC) of the oral cavity and demonstrated a significant as sociation between high cancer cell-expressed SOX2 protein and sig nificant lower risk of lymph node metastases [46]. According to them, this result is consistent with findings in lung SCC, reporting high SOX2 protein expression levels and SOX2 amplification to be correlated with better overall survival [47]. This is consistent with earlier data from the group of Perner on lung SCC, they reported that SOX2 amplification and overexpression was associated with better outcome [48]. In contrast, Neumann et al. correlated elevated SOX2 expression with lymph-node metastasis and distant spread of right-sided colon cancer in a matched pair collection of 57 carcinomas with distant spread and 57 cases without metastasis. Overall high SOX2 expression was reported in $21.1 \%$ of cases. Surprisingly, absence of SOX2 was associated with advanced T-category, T3/T4 [49]. In our study, SOX2 reactivity did also not correlate with higher tumor grades.
SOX2 amplification is quite characteristic for SCC pathogenesis and this can be correlated with the fact that lung SCC similar to SCC from other organs typically has a $3 q$ overrepresentation/amplification. In contrast, adenocarcinomas of the lung harbor much less SOX2 amplifications [28]. It should be noted that alterations of chromosome 3 , in particular $3 p$ deletions being frequently associated with $3 q$ gains, are considered early events in head and neck as well as lung carcinogenesis $[50,51]$. Interestingly, it has been shown that SOX2 and PIK3CA, both located at 3q26-q28 and generally coamplified in lung SCC, cooperate in the transition of lung dysplasia into cancer [52].

In SCLC, SOX2 amplifications were reported in $27 \%$ of cases being correlated with SOX2 expression. Inhibition of SOX2 protein expression by transfection of short hairpin RNA in SCLC cell lines with SOX expression resulted in reduced cell proliferation. It was hypothesized that SOX2 may represent a putative lineage-survival oncogene in SCLC. In addition, it was mentioned that induction of SOX2 in lung epithelial cells increased the number of neural progenitor cells [29].

Generally, SOX2 protein expression is widespread and was proven in the majority of primary SCC as well as breast cancer [53], testicular germ cell tumors [54], gastric [55] and pancreatic adenocarcinoma [56].

\subsection{SOX2 regulation and its interplay with SSX-SS18, H3K27me3 and} signaling pathways

In squamous lung and esophageal cancers, aberrant SOX2 expression was linked to the genomic amplification of its chromosomal location on chromosome $3 q 26.33$. Chromosome $3 q$ copy number gains are a common event in breast cancers and have been implicated as an independent predictor of poor prognosis in node-negative breast cancers [57]. Therefore some of the positive SOX2 synovial sarcoma cases were further subjected to a molecular study via FISH to detect amplification on the genetic level, but all were negative. None of the positive cases revealed an amplification, thus gene copy number alterations do not seem to play a role in SOX2 upregulation in this tumor entity.

This seems to be similar in some carcinoma subtypes. Claudia Lengerke and colleagues analyzed lymph node metastases of breast cancer to explore whether aberrant SOX2 expression is a result of gene amplification as reported in other carcinomas. Surprisingly, with the exception of one case of low level amplification in a score 3 primary tumor, the majority of analyzed samples did not show SOX2 gene amplifications, suggesting that at least in breast carcinomas expressing SOX2, the aberrant gene expression is mostly driven by other mechanisms [58].

Which other mechanisms have influence on SOX2 expression? A highly relevant study with respect to the interplay between the SS18. SSX fusion, histone modification and SOX2 expression was published in 2013 [32]. Kadoch and Crabtree reported that the SS18-SSX fusion protein of synovial sarcoma leads to alterations in the human SWI/SNF chromatin remodeling complex. Similar to SS18, the fusion protein incorporates into the SWI/SNF complex resulting in the exclusion of tumor suppressor gene BAF47 (also known as INI1 and SMARCB1), another component of the complex, resulting in its inactivation. The SWI/SNF complex antagonizes the activity of the Polycomb repressive complex 2 (PRC2) being responsible for trimethylation of lysine 27 of histone $\mathrm{H} 3$ (HeK27me3) by the methyltransferase EZH2 forming an essential component of the PRC2 complex and being considered a repressive mark for gene transcription [32,59]. This was actually the reason why we analyzed global $\mathrm{H} 3 \mathrm{~K} 27 \mathrm{me} 3$ expression in our study.

Interestingly, we found that SOX2 expression was correlated with global H3K27me3 expression in synovial sarcoma. In contrast, Kadoch and Crabtree reported that the altered SWI/SNF complex in synovial sarcoma binds to SOX 2 gene locus resulting in SOX2 activation by a local decrease in H3K27me3 [32]. This situation may be similar to seminoma in which a repressive H3K27me 3 mark at the SOX2 locus is responsible for SOX2 repression while there seems to be H3K27me3 
expression at least in a subset of neoplasms of this entity $[60,61]$.

As mentioned, methylation of Histone $\mathrm{H} 3$ at the lysine 27 residue is mediated by the histone methyltransferase EZH2. Enhancer of zeste homologue 2 (EZH2) showed high expression in cells possessing embryonic gene expression signature, while its amount declines with tissue maturation and differentiation [62]. Abnormal overexpression of EZH2 has been reported in a wide variety of tumor types including carcinomas, lymphomas, cutaneous melanoma, and soft tissue sarcomas [63].

Studies have revealed a complicated interaction between SOX2 and the WNT signaling pathway. It was reported that SOX2 antagonized WNT signaling to inhibit the differentiation of adult stem cells and osteoblast lineage, it enhanced tumorigenesis and self-renewal property of osteosarcomas by promoting the transcription of negative regulators of WNT signaling [64]. Other pathways apart from Wnt/ $\beta$-catenin signaling that have been associated with SOX2 are Hippo/YAP, Survivin/MAP4K4, EGFR/FOXO6, PI3K/Akt, Hedgehog and JAK/STAT $[30,65]$. It seems that SOX2 itself, like other SOX genes, does not possess sufficient affinity for DNA binding and that for transcription activity the recruitment of other protein partners like Nanog, OCT4 and Sall4 is required [30].

Kimura and colleagues recently explored specific markers and discovered that synovial sarcoma cell lines possessed heterogeneity by way of containing a sphere-forming subpopulation highly expressing Nanog, Oct 4 and SOX2. By expression microarray analysis, CXCR4 was identified to be highly expressed in the sphere subpopulation and correlated with stem-cell associated markers [35]. According to their study, stem-cell associated markers including SOX2 and SS18/SSX were highly expressed in the sphere/forming population of synovial sarcoma, hence SS18/SSX and its sphere-specific binding proteins might regulate tumor-initiating cells via epigenetic and/or transcriptional deregulation.

\subsection{Tumor progression of synovial sarcoma}

High expression of EZH2 is generally associated with advanced stages of tumor progression, aggressive tumor behavior, and dismal clinical outcome [66]. In synovial sarcoma, endogenous EZH2 expression correlated with $\mathrm{H} 3 \mathrm{~K} 27 \mathrm{me} 3$ at PcG target genes. It has been reported that high expression of EZH2 and H3K27me3 helps to distinguish poorly differentiated synovial sarcoma from monophasic and biphasic subtypes and is associated with unfavorable clinical outcome $[41,67]$. Our study does not provide such evidence, but it is important to mention the limitation of our tumor collective lacking data on metastatic spread and survival. Generally, the impact of H3K27me27 expression on cancer prognosis seems to be complex as there are also many studies reporting a better outcome in tumors with high expression, e.g. in colorectal and breast cancer [68,69].

Regarding synovial sarcoma, metastasis and tumor progression seem to be driven not only by epigenetic modifications like histone methylation but also additional chromosomal changes apart from the defining $t(X ; 18)(p 11.2 ; q 11.2)$ translocation and the activation of other genes and pathways distinct from the SS18-SSX gene fusion event [6,70]. The CINSARC signature of 67 genes correlating with chromosomal instability and prognosis in undifferentiated sarcoma was also highly significant in stratifying synovial sarcoma with respect to metastatic outcome [71]. Specific microRNAs being detectable in the blood have been correlated with clinical outcome. And apart from EZH2, IGFBP7, specific matrix metalloproteases, Secernin-1, NY-ESO-1, the CXCR4 pathway as well as PI3K/AKT/mTOR and RAS/MAPK sig. naling have been associated with metastatic risk [70]. Furthermore, it is important to note that synovial sarcoma is characterized by a recurrent pattern of DNA methylation that can be used to separate and diagnose this entity against 50 other soft tissue tumor types using genome-wide methylation analysis and bioinformatical classification algorithms. The methylome analysis provides in addition a global gene copy profile which may help to establish prognostic subgroups of this entity [72,73].

In summary, our study confirms the importance of the SS18-SSX gene fusion and its downstream targets SOX2 and H3K27me3 in synovial sarcoma. The entity provides a paradigm of a tumor that is primarily driven by alterations in the epigenome. The strength of the SS18-SSX alteration lies in the fact that the fusion gene has influence on two major players in epigenetic regulation. On one hand it leads to the inactivation of tumor suppressive functions of the SWI/SNF nucleosome remodeling complex and on the other hand it changes Histone chromatin marks that leads to the activation of the cancer stem cell transcription factor SOX 2 and other genes that are normally suppressed by the polycomb repressive complexes 1 and $2[6,41,74]$. The understanding of the pathway pathology of synovial sarcoma has advanced substantially in recent years and it is foreseeable that this will help in establishing effective therapy of this potentially lethal disease.

\section{Acknowledgements}

The technical assistance of Christiane Geier, Barbara Bergholz and other members of the technical staff of the institute of pathology of the Jena University hospital is gratefully acknowledged. We thank Katja Rüping and Thomas Knösel for TMA construction. Furthermore, the support of Emad H. El Gemeie, Hebat Allah M. Shaaban and Omnia M. Badawy in providing intellectual input and critical reading of the manuscript is highly appreciated.

\section{References}

[1] C. Fletcher, J.A. Bridge, P.C. Hogendoom, F. Mertens, WHO Classification of Tumours of Soft Tissue and Bone, IARC Press, Lyon, 2013.

[2] S.E. MIlls, Sometimes we don't look like our parents, Mod. Pathol. 8 (May (4) (1995) 347 (PubMed PMID: 7567927)

[3] M. Lehnhardt, A. Daigeler, H.H. Homann, J. Hauser, S. Langer, L. Steinsträsser C. Soimaru, A. Puls, H.U. Steinau, Importance of specialized centers in diagnosis and treatment of extremity-soft tissue sarcomas. Review of 603 cases, Chirurg 80 (Apr (4)) (2018) 341-347, http://dx.doi.org/10.1007/s00104-008-1562-2 (PubMed PMID: 18523742).

[4] I. Petersen, B. Günther, K. Mildner, F. Subhi, T. Knösel, A. Altendorf-Hofmann, D. Katenkamp, Update from the soft tissue tumour registry in Jena, Pathologe 32 (Feb (1)) (2011) 40-46, hrtip//dx doisorg/10.1007/s00292-010-1399-6 (Review. German. PubMed PMID: 21170535)

[5] M.F. Amary, F. Berisha, C. Bemardi Fdel, A. Herbert, M. James, J.S. Reis-Filho, C. Fisher, A.G. Nicholson, R. Tiraboscc, T.C. Diss, A.M. Fanagan, Detection of SS18.
SSX fusion transecripts in fommalin.fixed paraffin-embedded neoplasmer analysis of SSX fusion transeripts in fommalin-fixed paraffin-embedded neoplasms: aralysis of sarcoma, Mod. Pathol. 20 (Apr (4) (2018) 482-496 (Epub 2007 Mar 2. PubMed sarcoma, Mod. Patho 17334349 ).

[6] T.O. Nielsen, N.M. Poulin, M. Ladanyi, Synovial sarcoma: recent discoveries as a roadmap to new avenues for therapy, Cancer Discov, 5 (Feb (2)) (2015) 124-134, hitn://dx doi.0rg/10.1158/2159-8200 (CD-14-1246. Fpub 2015 Jan 20 ReviewPubMed PMID: 25614489; PubMed Central PMCID: PMC4320664).

[7] P. Bergh, JM. Mels-Kindblom, F. Gherlingoni, O. Berlin. P. Bacchinl, F Bertont,

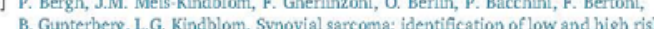
6. Gunterverg, L.G. Kunabiom, Synovial sarcoma: identification of low and high

[8] JF. Fersch, J.M. Meis, Synowial a arcoma of the abdominal wall, Cancer 72 (Jul (2)) (1993) $469-477$ (PubMed PMID: 8391380 )

[9] J.A. Roth, F.M. Enzinger, M. Tannenbaum, Synovial sarcoma of the neck: a followup study of 24 cases, Cancer 35 (Apr (4)) (1975) 1243-1253 (PubMed PMID: 163680).

(2) cases and review of the literature, Cancer 50 (Jul (2) PMID: 6282438)

[11] S. Suster, C.A. Moran, Primary synovial sarcomas of the mediastinum: a clinicopathologic, immunohistochemical, and ultrastructumal study of 15 cases, Am. J. Surg. Pathol. 29 (May (5)) (2005) 569-578 (PubMed PMID: 15832079).

[12] C. Fisher, A. Folpe, H. Hashimoto, S. W. Weiss, Intra-abdominal synovial sarcoma: a clinicopathological study, Histopathology 45 ( $(\mathrm{Sep}$ (3)) (2004) 245-253 (PubMed PMID: 15330802).

[13] T. Krösel, S. Heretsch, A. Altendorf-Hofmann, P. Richter, K. Katerikamp, D. Katenkamp, A. Berndt, L. Petersen, TLE1 is a robust dlagnostic blomarker for synovial sarcomas and correlates with $t(X ; 18)$ : analysis of 319 cases, Eur. J. Cance 46 (Apr (6)) (2010) 1170-1176, http://dx.doL.org/10.1016/j.ejce.2010.01.03 (Epub 2010 Feb 25. PubMed PMID. 20189377)

[14] J.J. Lewis, C.R. Antonescu, D.H. Leung, D. Blumberg, J.H. Healey, J.M. Woodruff, M.F. Brennan, Synovial sarcoma: a multivariate analysis of prognostic factors in 11 patients with primary localized tumors of the extremity, J. Clin. Oncol. 18 (May

[15] J.A. Chan, M.E. MeMenamin, C.D. Fletcher, Synovial sarcoma in older patients: 
clinicopathological analysis of 32 cases with emphasis on whusual histological features, Histopathology 43 (Jul (1)) (2003) 72-83 (PubMed PMID: 12823715)

[16] M. Pelmus, L. Guition, L. Hostein, G. Sierankowski, C. Lussan, J.M. Coindre, Monophasic fibrous and poorly differentiated synovial sarcoma: in munohistochemical reassessment of 60 t(X:18)(SYT-SSX)-positive cases, Am. J. Surg. Pathol. 26 (Nov (11)) (2002) 1434-1440 (PubMed PMID: 12409719).

[17] J. Clark, P. Joccues, An Jew, S. Gill, J. Shipley, A.M. Chan, B.A. Gusterson, C.S. Cooper, Identification of novel genes, SYT and SSX, involved in the t(X;18) (p11.2; q11.2) translocation found in human synovial sarcoma, Nat. Genet. 7 (Aug (4)) (1994) 502-508 (PubMed PMID: 7951320).

[18] A.A. Sandberg, J.A. Bridge, Undates on the cytogenetics and molecular genetics of bone and soft tissue tumors. Synovial sarcoma, Cancer Genet. Cytogenet. 133 (Feb (1)) (2002) 1-23 (Review. PubMed PMID: 11890984).

[19] M. Soulez A.J. Saurin, P.S. Freemont, J.C. Knight, SSX and the synovial-sarcomaspecific chimaeric protein SYT-SSX co-localize with the human Polycomb group complex, Oncogene 18 (Apr (17)) (1999) 2739-2746 (PubMed PMID: 10348348),

[20] C.B. Garcla, C.M. Shaffer, J.E. Eid, Genome-wide recruitment to Polycomb-modiffed chromatin and activity regulation of the synovial sarcoma oncogene SYT-SSX2, BMC Genom. 13 (May) (2012) 189 (PubMed PMID: 22594313; PubMed Centra) PMCID: PMC3460777)

[21] K. Takahashi, S. Yamanaka, Induction of pluripotent stem cells from mouse em. bryonic and adult fibroblast cultures by defined factors, Cell 126 (4) (2006) 663-676 (Epub 2006 Aug 10. PubMed PMID: 16904174).

[22] A.E. Pen, U.B. Jensen, Current status of treating neurodegenerative disease with Induced pluripotent stem cells, Acta Neurol. Scand. 135 (Jan (1)) (2017) 57-72, http: $/ / \mathrm{dx}$.doli.or

[23] K. Ohnlshl, K. Seml, T. Yamamoto, M. Shimizu, A. Tanaka, K. Mitsunaga, K. Okita, K. Osafune, Y. Arioka, T. Maeda, H. Socjima, H. Moriwaki, S. Yamanaka, K. Woltjen, K. Osafune, Y. Arioka, T. Maeda, H. Soejima, H. Moriwaki, S. Yamanaka, K. Woltjen,
Y. Yamada, Premature termination of reprogramming in vivo leads to cancer deY. Yamada, Premature termination of reprogramming in vivo leads to cancer
velopment through altered epigenetic regulation, Cell 156 (Feb (4)) (2014) 663-677, http://dx.doL.org/10.1016/j.cell.2014.01.005 (PubMed PMID: 24529372).

[24] T. Magnuson, C.J. Epstein, L.M. Silver, G.R. Martin, Pluripotent embryonic stem cell lines can be derived from tw5/tw5 blastocysts, Nature 298 (Aug (5876)) (1982) 750-753 (PubMed PMID: 7110310).

[25] I. Gutierrez-Aranda, V. Ramos-Mejia, C. Bueno, M. Munoz-Lopez, P.J. Real, A. Mácia, L. Sanchez, G. Ligero, J.L Garcia-Parez, P. Menendez, Human induced pluripotent stem cells develop teratoma more efficiently and faster than human embryonic stem cells regardless the site of injection, Stem Cells 28 (Sep (9)) (2010) 1568-1570, http://dx.doi.org/10.1002/stem. 471 (PubMed PMID: 2064103 PubMed Central PMCID: PMC2996086).

[26] A. Rizzino, Sox2 and Oet-3/4: a versatile pair of master regulators that orchestrate the self-renewal and pluripotency of embryonic stem cells, Wliey Interdlscip. Re Syst. Biol. Med. 1 (Sep-Oct (2)) (2009) 228-236, http://dx.doLorg/10.1002/wsbr.

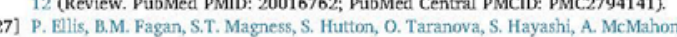
M. Rao, L. Pevny, soX2, a persistent marker for multipotential neural stem cells M. Rao, L. Pevny, soX2, a persistent marker for mutipotential neural stem cells
derived from embryonic stem cells, the embryo or the adult, Dev. Neurosci. 26 (Mar-Aug (2-4)) (2004) 148-165.

[28] N. Karachaliou, R. Rosell, S. Viterl, The role of SOX2 in small cell lung cancer, lung adenocarcinoma and squamous cell carcinoma of the lung, Transl. Lung Cancer Res. 2 (Jun (3) (2013) 172-179, http://dx.doL.org/10.3978/j.issn.2218-6751.2013.0 01 (Review. PubMed PMID: 25806230; PubMed Central PMCID: PMC4367598)

[29] C.M. Rudin, S. Durinck, E.W. Stawiski, J.T. Poirler, Z. Modrusan, D.S. Shames, E.A. Bergbower, Y. Guan, J. Shin, J. Guillory, C.S. Rivers, C.K. Foo, D. Bhatt, J. Stinson, F. Gnad, P.M. Haverty, R. Gentleman, S. Chaudhuri, V. Janakiraman, B.S. Jaiswal, C. Parikh, W. Yuan, Z. Zhang, H. Koeppen, T.D. Wu, H.M. Stern, R.I. Yauch, K.E. Huffman, D.D. Paskulin, P.B. Wlei, M. Varella-Garcia, A.F. Gazdar, F.J. de Sauvage, R. Bourgon, J.D. Minna, M.V. Brock, S. Seshagirl, Comprehensive genomic analysis identifies SOX2 as a frequently amplified gene in small-cell lun cancer, Nat. Genet. 44 (Oct (10)) (2012) 1111-1116, http://dx doLorg/10.1038/ ng. 2405 (Epub 2012 Sep 2. PubMed PMID: 22941189; PubMed Central PMCID: PMC3557461)

[30] S.G. Cao, Z.J. Ming, Y.P. Zhang, S.Y. Yang, Sex-determining region of Y chromosome-related high-mobility-group box 2 in malignant tumors: current opinions and anticancer therapy, Chir. Med. J. (Eng.) 128 (Feb (3)) (2015) 384-389, http://dx. dol.org/10.4103/0366-6999.150112 (Revlew. PubMed PMID: 25635436; PubMed Central PMCID: PMC4837871)

[31] M. Herreros-Villanueva, J.S. Zharg, A. Koenig, E.V. Abel, T.C. Smyrk, W.R. Bamlet, A.A. de Narvajas, T.S. Gomez, D.M. Simeone, L. Bujanda, D.D. Blladeau, SOX2 promotes dedifferentiation and imparts stem cell-like features to pancreatic cances
cells, Oncogenesis 2 (Aug) (2013) e61, http://dx doi.org/10.1038/oncsis.2013.23 (PubMed PMID: 23917223; PubMed Central PMCID: PMC3759123

[32] C. Kadoch, G.R. Crabtree, Reversible disruption of mSWL/SNF (BAF) complexes by the SS18-SSX oncogenic fusion in synovial sarcoma, Cell $153(\mathrm{Mar}$ (1)) (2013) 71-85, http://dx.doi.org/10.1016/.,cell.2013.02.036 (PubMed PMID: 23540691; PubMed Central PMCID: PMC3655887).

[33] Chen S, Li X, Lu D, Xu Y, Mou W, Wang L, Chen Y, Liu Y, Li X, Li LY, Llu L, Stupack D, Reisfeld RA, Xiang R, Li N, SOX2 regulates apoptosis through MAP4K4-survivin signaling pathway in human lung cancer cells. Carcinogenesis 35Mar (3)): 2014, 613-23. 10.1093/carcin/bgt371. Epub 2013 Nov 14. PubMed PMID: 24233838.

[34] C. Sun, L. Sun, Y. Li, X. Kang, S. Zhang, Y. Liu, Sox2 expression predicts poor survival of hepatocellular carcinoma patients and it promotes liver cancer cell invasion by activating Slug, Med. Oncol. 30 (Jun (2)) (2013) 503, http://dx.doi.org $10.1007 / 812032-013-0503-1$
[35] T. Kimura, L. Wang, K. Tabu, M. Tsuda, M. Tanino, A Maekawa, H. Nishihara, H. Hiraga, T. Taga, Y. Oda, S. Tanaka, ldentification and analys is of CXCR4-positive synovial sarcoma-initiating cells, Oncogene 35 (Jul (30)) (2016) 3932-3943 http://dx.doL.org/10.1038/onc.2015.461 (Epub 2015 Dec 7. PubMed PMID) 26640147).

[36] K. Rüping, A. Altendorf-Hofmann, Y. Chen, E. Kampmann, S. Gibis, L Lindner, D. Katenkamp, I. Petersen, T. Knösel, High IGF2 and FGFR3 are associated with tumour progression in undifferentlated pleomorphic sarcomas, but EGFR and FGFR3 mutations are a rare event, J. Cancer Res. Clin. Oncol. 140 (Aug (8)) (2014) 1315-1322, http://dx.doi.org/10.1007/s00432-014.1700-9 (Epub 2014 May 8. PubMed PMID: 24804818)

[37] J. Kononen, L. Bubendorf, A. Kallioniemi, M. Bärlund, P. Schraml, S. Leighton, J. Torhorst, M.J. Mihatsch, G. Sauter, O.P. Kallioniemi, Tissue microarrays for high throughput molecular profiling of tumor specimens, Nat. Med. 4 (Jul (7)) (1998) 844-847 (PubMed PMID: 9662379).

[38] K. Katenkamp, P. Richter, T. Slatosch, D. Katenkamp, A. Bemdt, [Simultaneous analys $(5$ of $t$ X:18) by FISH - und SYT/SSX-RT.PCR in synovinl sarcomal, Pathologe 26 OMar (2)) (2005) 111-116 (German. PubMed PMID; 15662499).

[39] Y.J. Lu, S. Birdsall, B. Summersgill, D. Smedley, P. Osin, C. Fisher, J. Shipley, Dusa colour fluorescence in situ hybridization to paraffin-embedded samples to deduce the presence of the der $(X) t(X ; 18)(p 11.2 ; q 11.2)$ and involvement of either the SSX or SSX2 gene: a diagnostic and prognostic aid for synovial sarcoma, J. Pathol. 187 (Mar (4)) (1999) 490-496 (PubMed PMID: 10398111).

[40] N. Naka, S. Takenaka, N. Ataki, T. Miwa, N. Hashimoto, K. Yoshioka, S. Joyama, K. Hamada, Y. Tsukamoto, Y. Tomita, T. Ueda, H. Yoshlkawa, K. Itoh, Synovlal sarcoma is a stem cell malignancy, Stem Cells 28 (Jul (7) $(2010)$ 1119-1131, http://dx doL.org/10.1002/stem. 452 (PubMed PMID: 20518020)

[41] S.K. Zöllner, C. Rössig, J.A. Toretsky, Synovlal sarcoma is a gateway to the role of chromatin remodeling in cancer, Cancer Metastasis Rev. 34 (Sep (3)) (2015) 417-428, http://dx.doi.org/10.1007/s10555-015-9575-z (Review. PubMed PMID 26277104).

[42] A.G. Smith, Embryo-derived stem cells: of mice and men, Arnu Rev, Cell Dev. Biol 17 (2001) 435-462 (Revlew. PubMed PMID: 11687496).

[43] K. Okita, S. Yamanaka, Induced pluripotent stem cells: opportunities and cha] lenges, Philos. Trans. R. Soc. Lond. B: Btol. SCL. 366 (Aug (1575)) (2011) 2198-2207, http://dx, doLorg/10.1098/1rstb. 2011.0016 (Revlew. PubMed PMID: 21727125; PubMed Central PMCID: PMC3130417).

[44] J.E. Visvader, G.J. Lindeman, Cancer stem cells in solid tumours: accumulatin evidence and unresolved rquestions, Nature Rev. Cancer 8 (Oct (10)) (2008) 755-768, http://dx doLorg/10.1038/rre2499 (Epub 2008 Sep 11. Review. PubMed PMID: 18784658)

[45] G. Gu, J. Yuan, M. Wills, S. Kasper, Prostate cancer cells with stem cell characteristics reconstitute the original human tumor in vivo, Cancer Res. 67 (May (10) )

[46] L. Züllig, M. Roessle, C. Weber, N. Graf, S.K. Haerle, W. Jochum, S.J. Stoeckli, H. Moch, G.F. Huber, High sex detemining region Y-box 2 expression is a negative predictor of occult lymph node metastasis in early squamous cell carcinomas of the oral cavity, Eur. J. Cancer 49 (May (8)) (2013) 1915-1922, http://dx.doi.org/10 1016/. ejea.2013.01.005 (Epub 2013 Feb 12. PubMed PMID: 23414798).

[47] Y. Lu, C. Futtner, J.R. Rock, X. Xu, W. Whitworth, B.L. Hogan, M.W. Onaitis, Evidence that SOX2 overexpression is oncogenic in the lung, PLoS One 5 (Jun (6)) (2010) e11022, http://dx.dol.org/10.1371/journal. pone.0011022 (PubMed PMID 20548776; PubMed Central PMCID: PMC2883553).

[48] T. Wilbertz, P. Wagner, K. Petersen, A.C. Stiedl, V.J. Scheble, S. Maier, M. Reischl, R. Mikut, N.K. Altorkl, H. Moch, F. Fend, A. Staebler, A.J. Bass, M. Meyerson, M.A. Rubin, A. Soltermann, C. Lengerke, S. Perner, soX2 gene amplification and protein overexpression are associated with better outcome in squamous cell lung cancer, Mod. Pathol. 24 (Jul (7)) (2011) 944-953, http://dx.doi.org/10.1038/ modpathol.2011.49 (Epub 2011 Apr 1. PubMed PMID: 21460799)

49] J. Neumann, F. Bahr, D. Horst, L. Kriegl, J. Engel, R.M. Luque, M. Gerhard, T. Kirchner, A. Jung, SOX2 expression correlates with lymph-node metastases and distant spread in right-sided colon cancer, BMC Cancer 11 (Dec) (2011) 518, http:/ dx.dol.org/10.1186/1471-2407-11-518 (PubMed PMID: 22168803; PubMed Central PMCID: PMC3267776

[50] U. Bockmühl, A. Schwendel, M. Dietel, I. Petersen, Distinct patterns of chromosomal alterations in high- and low-grade head and neck squamous cell carcinomas, Cancer Res. 56 (Dec (23)) (1996) 5325-5329 (PubMed PMID: 8968077).

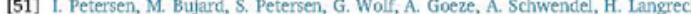
K. Gellert, M. Reichel, K. Just, S. du Manoir, T. Cremer, M. Dietel, T. Ried, Patterns of chromosomal imbalances tradenocarchoma and scuamous cell carcinoma of the lung, Cancer Res. 57 (Jun (12)) (1997) 2331-2335 (PubMed PMID: 9192802)

[52] B.R. Kim, E. Van de Laar, M. Cabanero, S. Tarumi, S. Hasenoeder, D. Wang, C. Virtanen, T. Suzuki, B. Bandarchi, S. Sakashita, N.A. Pham, S. Lee, S. Keshavjee, T.K. Waddell, M.S. Tsao, N. Moghal, SOX2 and PI3K cooperate to induce and stabilize a squamous-committed stem cell injury state during lung squamous cell carciroma pathogenesis, PLoS Biol. 14 (Nov (11)) (2016) e1002581, http://dx.dol. org/10.1371/journal.pbio.1002581 (eCollection 2016 Nov. PubMed PMID: 27880766; PubMed Central PMCID: PMC5120804

[53] Y. Chen, L. Shl, L. Zhang, R. Li, J. Lang, W. Yu, L. Sun, X. Yang, Y. Wang, Y. Zhang, Y. Shang, The molecular mechanism governing the oncogenic potential of SOX2 in breast cancer, J. Biol. Chem. 283 (Jun (26)) (2008) 17969-17978, http://dx. doi. org/10.1074/Jbc.M802917200 (Epub 2008 May 2. PubMed PMID: 18456656)

[54] K. Blermann, LC. Heukamp, K. Steger, H. Zhou, F.E. Franke, V. Sonnack, R. Brehn, J. Berg, P.J. Bastian, S.C. Muller, L. Wang-Eckert, R. Buettner, Genome-wide expression profiling revesls new insights into pathogenesis and progression of test. cular germ cell tumors, Cancer Genom. Proteom. 4 (Sep-Oct (5)) (2007) 359-367 
(PubMed PMID: 17993720)

[55] T. Tsukamoto, T. Mizoshita, M. Mhara, H. Tanaka, Y. Takeraka, Y. Yamamura, S. Nakamura, T. Ushijima, M. Tatematsu, Sox2 expression in human stomach ade. nocarcinomas with gastric and gastric-and-intestinal mixed phenotypes,
Histopathology 46 (Jun (6)) (2005) 649-658 (PubMed PMID: 15910596).

[56] Y. Sanatia, K. Yoshida, M. Ohara, M. Oeda, K. Konishi, Y. Tsutani, Histopathologic evaluation of stepwise progression of pancreatic carcinoma with inmunohistochemical analysis of gastric epithelial transeription factor SOX2: comparison of expression patterns between invasive components and cancerous of nonneoplastic intraductal components, Pancreas 32 (Mar (2)) (2006) 164-170 (PubMed PMID: 16552336)

[57] E.A. Janssen, J.P. Baak, M.A. Guervós, P.J. van Diest, M. Jiwa, M.A. Hermsen, In lymph node-negative invasive breast carcinomas, specific chromosomal aberrations are strongly assoclated with high mitotic activity and predict outcome more ace rately than grade, tumour diameter, and oestrogen receptor, J. Pathol. 201 (Dec (4) (2003) 555-561 (PubMed PMID: 14648658)

[58] C. Lengerke, T. Fehm, R. Kurth, H. Neubauer, V. Scheble, F. Müler, F. Schneider, K. Petersen, D. Wallwiener, L. Kanz, F. Fend, S. Perner, P.M. Bareiss, A. Staebler, Expression of the embryonic stem cell marker SOX2 in early-stage breast carcinoma BMC Cancer 11 (Jan) (2011) 42, http//dx dol.org/10.1186/1471-2407-11-42 (PubMed PMID: 21276239; PubMed Central PMCID: PMC3038979).

[59] C. Kadoch, R.A. Copeland, H. Kellhack, PRC2 and SWI/SNF chromatin remodelling complexes in health and disease, Biochemistry 55 (Mar (11)) (2016) 1600-1614, http://dx.doi.org/10.1021/acs.biochem.5b01191 (Epub 2016 Feb 17. Review. PubMed PMID: 26836503).

[60] R. Kushwaha, N. Jagadish, M. Kustagi, G. Mendiratta, M. Seandel, R. Soni, J.E. Korkola, V. Thodima, A. Califano, G.J. Bosi, R.S.K. Chagant, Mechanism and role of SOX2 repression in seminoma: relevance to human germline specification, (1) PMCID: PMC4939754)

[61] D.G. Kristensen, O. M.ynarkka, J.E. Nielsen, G.K. Jacobsen, E. Rajpert-De Meyts, D.G. Kristensen, O. Mlynarska, J.E. Nielsen, G.K. Jacobsen, E. Rajpert-De Meyts,
K. Almstrup, Heterogeneity of chromatin modifications in testicular spermatocytic K. Almstrup, Heterogeneity of chromatin modifications in testicular spermatocytic seminoma point toward an epigenetically unstable phenotype, Cancer Genet.
(Sep (9)) (2012) 425-431, http://dx.doi.org/10.1016/j.cancergen.2012.05.003.

[62] L.E. Surface, S.R. Thornton, L.A. Boyer, Polycomb group proteins set the stage for L.E. Surface, S.R. Thornton, L.A. Boyer, Polycomb group proteins set the stage for
early lineage commitment, Cell Stem Cell 7 (Sep (3)) (2010) 288-298, http://dx. early lineage commitment, Cell Stem Cell 7 (Sep (3)) (2010) 288-298, http

[63] C.J. Chang, M.C. Hung, The role of EZH2 in tumour progression, Br. J. Cancer 106 (Jan (2)) (2012) 243-247, http://dx.dol.org/10.1038/bjc.2011.551 (Epub 2011 Dec 20. Review. PubMed PMID: 22187039; PubMed Central PMCID: PMC3261672).

[64] S. Chen, Y. Xu, Y. Chen, X. Li, W. Mou, L. Wang, Y. Liu, R.A. Reisfeld, R. Xiang, D. Lv, N. Li, SOX2 gene regulates the transcriptional network of oncogenes and affects tumorigenesis of human lung cancer cells, PLoS One 7 (5) (2012) e36326, http://dx.dol.org/10.1371/joumal.pone.0036326 (Epub 2012 May 15. PubMed PMID: 22615765; PubMed Central PMCID: PMC3352903,

[65] S.M. Rothenberg, K. Concannon, S. Cullen, G. Boulay, A.B. Turke, A.C. Faber, E.L. Lockerman, M.N. Rivera, J.A. Engelman, S. Maheswaran, D.A. Haber,
Inhibition of mutant EGFR in lung cancer cells triggers SOX2-FOXO6-dependent survival pathways, Ellfe 4 (Feb) (2015), http://dx.dol.org/10.7554/elife.06132 (PubMed PMID: 25686219; PubMed Central PMCID: PMC4384750)

[66] A. Chase, N.C. Cross, Aberrations of EZH2 in cancer, Clin. Cancer Res. 17 (May (9) (2011) 2613-2618, http://dx.dol.org/10.1158/1078-0432 (CCR-10-2156. Epub 2011 Mar 2. Review. PubMed PMID: 21367748).

[67] Y.C. Changchehien, P. Tátrai, G. Papp, J. Sápi, L. Fónyad, M. Szendrói, Z. Pápai, Poorly differentiated synovial sarcoma is associated with high expression of en hancer of zeste homologue 2 (EZH2), J. Transl. Med. 10 (Oct) (2012) 216, http:/ dx.dol.org/10.1186/1479-5876-10-216 (PubMed PMID: 23110793; PubMed Central PMCID: PMC3494513).

[68] W.K. Bae, K.H. Yoo, J.S. Lee, Y. Kim, I.J. Chung, M.H. Park, J.H. Yoon, P.A. Furth, L. Hennighausen, The methyltransferase EZH2 is not required for mammary cance development, although high EZH2 and low H3K27me 3 correlate with poor pros. nosis of ER-positive breast cancers, Mol. Carcinog. 54 (Oct (10)) (2015) 1172-1180, hosto://dx. doL Lorg/10.1002/mc 22188 (Epub 2014 Jul 7. PubMed PMID, 25043748, PubMed Central PMCID: PMC4286524).

[69] A. Benard, L.J. Goossens Beumer, A.Q. van Hoesel, H. Horati, H. Putter, E.C. Zeestraten, C.J. van de Velde, P.J. Kuppen, Prognostic value of polycomb proteins EZH2, BMIII and SUZ12 and histone modification $\mathrm{H} 3 \mathrm{~K} 27 \mathrm{me} 3$ in colorecta proteins EZH2, BMI1 and SUZ12 and histone modification H3K27me 3 in colorecta cancer, PLoS One 9 (Sep (9)) (2014) e108265, http://dx.dol.org/10.1371/jow PMCID: PMC4171510).

[70] R. de Necochea-Campion, L.M. Zuckerman, H.R. Mirshahidi, S. Khosrowpour, C.S. Chen, S. Mirshahidi, Metastatic biomarkers in synovial sarcoma, Biomark. Res. C.S. Chen, S. Mirshahidi, Metastatic biomarkers in synovial sarcon
5 (Feb) (2017) 4, http://dx.doi.org/10.1186/s40364-017-0083-x.

[71] P. Lagarde, J. Przybyl, C. Brulard, G. Pérot, G. Pierron, O. Delartre, R. Sciot A. Wozniak, P. Schöffski, P. Terrier, A. Neuville, J.M. Coindre, A. Itallano, D. Orbach, M. Debiec-Rychter, F. Chibon, Chromosome instability accounts for D. Orbach, M. Debiec-Rychter, F. Chibon, Chromosome instability accounts for
reverse metastatic outcomes of pediatric and adult synovial sarcomas, J. Clin. reverse metastatic outcomes of pediatric and adult synovial sarcomas, J. Clin. (Epub 2013 Jan 14. PubMed PMID: 23319690).

[72] I. Petersen, Soft tissue sarcoma entities - knowing the adversary, Traum 1. Petersen, Soft tissue sarcoma entities - knowing the adversary, Trauma
Berufskrankh 20 (2018) 25-32, http://dx. doL.org/10.1007/s10039-017-0339-6.

[73] C. Koelsche, W. Hartmann, D. Schrimpf, D. Stichel, S. Jabar, A. RAnft, D.E Reuss, F. Sahm, D.W. Jones, M. Bewerunge-Hudler, M. Trautmann, T. Klingebeil, C. Vokuhl, M. Gessler, E. Wardelmann, I. Petersen, D. Baumhoer, U. Flucke, C. Antonescu, M. Esteller, S. Fröh ling, M. Kool, S.M. Pfister, G. Mechtersheimer, U. Dirksen, A. von Deimling, Array-based DNA-methylation profiling in sarcomas with small blue round cell histology provides valuable dlagnostc information, Mod Pathol. (March) (2018), http://dx. doi.org/10.1038/s41379-018-0045-3 [Epul ahead of print] PMID: 29572501.

[74] A. Banito, X. Li, A.N. Laporte, J.S. Roe, F. Sanchez-Vega, C.H. Huang, A.R. Dancsol, K. Hatzi, C.C. Chen, D.F. Tschaharganeh, R. Chandwani, N. Tasdemir, K.B. Jones, M.R. Capecchi, C.R. Vakoc, N. Schultz, M. Ladanyi, T.O. Nielsen, S.W. Lowe, The SS18-SSX oncoprotein hijacks KDM2B-PRC1.1 to drive synovial sarcoma, Cancer Cell (Feb) (2018), http://dx.doL.org/10.1016/j.ccell.2018.01.018 plit: S1535. 6108(18)30018-7. [Epub ahead of print] PubMed PMID: 29502955. 


\section{DISCUSSION}

Soft tissue sarcomas are rare and represent less than $1 \%$ of all cancer types. In recent years between 3500 and 3750 new cases were registered in Germany each year. They can roughly be subdivided into two groups: entities with single, well-characterized driver mutations and sarcomas with a complex genotype (Petersen 2017).

Synovial sarcoma is classified as a soft tissue tumor of uncertain cellular origin (Fletcher et al. 2013). It gets its name from its microscopic similarity and proximity to the synovium, but in reality the development of tumor cells is not necessarily of synovial origin. While it is a soft tissue tumor typically found in the arms or legs and usually close to tendon sheaths and joint capsules, it can also occur in other locations, such as the heart, brain, and prostate. Synovial Sarcoma accounts for 5\%-10\% of all STS (Spurrell et al. 2005) and $10 \%-20 \%$ of STS in adolescents and young adults (Nielsen et al. 2015).

Although its cellular origin is unclear, Synovial sarcoma (SS) is generally divided into two main histological subtypes: monophasic and biphasic. Monophasic SS is characterized by the presence of spindle cells and the absence or near-absence of glandular epithelial cells, whereas biphasic SS has equal presence of both spindle cells and glandular epithelial cells (Spurrell et al. 2005). In addition, monophasic SS displays fibrous and sarcomatous cells that are relatively uniform and small and form sheets. In contrast, biphasic SS presents with an epithelial appearance. Another characteristic of $\mathrm{SS}$ is the unique chromosomal translocation ( $\mathrm{t} \mathrm{X} ; 18$ ), which results in fusion of the SYT gene to the $S S X 1, S S X 2$, or, on rare occasions, the $S S X 4$ gene (Nielsen et al. 2015).

Recently, major changes took place in the understanding of cancer biology, emphasizing the importance of cancer stem cells, and supporting the suggested theory that tumors arise from these cells rather than terminally differentiated cells.

Embryonic cells, whose biology is governed by stem cell transcription factors like SOX2, and cancer stem cells, are thought to be closely related. The Embryonic stem cells proliferate without apparent limit; they can be propagated clonally and are 
not subject to contact inhibition or anchorage dependence. These are typical features of transformed or tumor cells and this is why embryonic stem cells can be considered as conditional tumor cells (Smith 2001). Evidence has recently been accumulating to support the hypothesis that solid tumors contain a small population of cancer-stem like cells, which exhibit self-renewing capacities and are responsible for tumor maintenance and metastases (Visvader and Lindeman 2008).

\section{The aim of our study was to:}

(1) Examine SOX2 expression in synovial sarcoma.

Transcription factor SOX2 was proved to be amplified in different types of tumors including small cell lung cancer and many forms of squamous cell carcinoma (Karachaliou et al. 2013)

(2) Compare the expression of SOX2 in synovial sarcoma to other soft tissue tumors.

To fulfill this aim, we analzyed tissue microarrays that were prepared in the institute of Pathology, Jena University and included a wide variety of soft tissue tumors ranging from Fibrosarcoma, Rhabdomyosarcoma, dedifferentiated Liposarcoma, undifferentiated pleomorphic sarcoma and many more.

(3) Analyze mechanisms that may affect SOX2 expression.

This included an analysis to understand the SOX2 gene status utilizing fluorescence in situ hybridization (FISH) technique and studying the H3K27me3 in synovial sarcoma.

\section{$\underline{\text { Role of SOX2 in synovial sarcoma and other cancer types }}$}

The study was carried out on 60 cases of synovial sarcoma and 343 cases of the different other soft tissue tumors that were referred to the Jena consultation and reference center of soft tissue tumors. All the tumors were intensively histologically studied via at least two soft tissue tumors experts and were further subjected to a wide 
panel of biomarkers to direct and confirm the histological diagnosis. All the synovial sarcoma cases were subjected to FISH to analyze the characteristic $t(x ; 18)$ translocation.

The other 343 cases of various soft tissue tumor entities were employed in the production of the tissue microarrays.

Out of the above mentioned 60 synovial sarcomas, 35 (60\%) were SOX2 positive and $25(40 \%)$ were negative. The expression was variable but worth noticing was the fact that all the grade 1 tumors were positive while less than $60 \%$ of grade 2 and grade 3 revealed a positive staining. Similarly, there was a minor difference of SOX2 positivity in the low proliferative group (56\%) versus moderately to highly proliferating tumors $(63 \%)$. This suggests that SOX2 does not seem to be essential for tumor progression, but may play a role in the tumor initiation itself (Zayed \& Petersen 2018).

This is also supported by the fact that the majority of the undifferentiated sarcomas were SOX2 negative in first place, again hinting that the transcription factor Sox 2 is probably not essential in the tumor progression phase.

This was also stated by Abd El-Maqsoud et al. (2014) who identified Sox2 expression in ductal carcinoma in situ (DCIS) cases with a higher expression rate than seen in invasive carcinomas, suggesting a role of Sox 2 in the initial stages of breast carcinogenesis. In this study, Sox 2 expression was significantly associated with comedo type, negative hormone receptor status, and the triple-negative phenotype. However a positive association of Sox 2 expression with high-grade DCIS was not reached.

The relationship between SOX2 expression and tumor behavior is highly controversial. The fact that some studies reported even better tumor behavior with SOX2 expression is to be highlighted. For example, in a study conducted by Züllig and colleagues, they managed to investigate and analyze the process of early lymphatic metastasisis in squamous cell carcinoma of the oral cavity and demonstrated a significant association between cancer cells that strongly expressed SOX2 and a lower risk of lymph node metastases. Lu, (2010) and colleagues also reported that patients with squamous tumors with expression of SOX2 mRNA above the median enjoyed a better prognosis than those with lower levels of expression. 
This is also consistent with Wilbertz and colleagues who reported in squamous cell lung carcinoma that their data clearly demonstrate an association between elevated SOX2 expression and indicators of better patient outcome, most importantly prolonged overall survival. Furthermore, increased levels of SOX2 amplification indicate a better histological differentiation grade and a trend to improved patient survival.

Consistently, Bass et al.'s (2009) findings, indicated that patients with lung squamous cell carcinomas harboring an embryonic stem cell-like gene expression signature, including SOX2 expression, exhibited significant better survival than patients with tumors lacking this signature.

On the contrary, Neumann et al. demonstrated that increased expression of either SOX2 or nuclear $\beta$-catenin was associated with distant metastasis in right-sided colon cancer. Additionally, SOX2 was also associated with lymph-node metastases. According to them, this data underlined the importance of stemness-associated markers for the identification of colon cancer with a high risk for distant spread.

According to Russo et al., SOX2 overexpression upregulated pluripotency and epithelial-mesenchymal transition (EMT) transcription factors, along with growth, angiogenic and lymphangiogenic factors, and promoted prostate cancer cell invasiveness.

In our study, SOX2 reactivity did also not correlate with higher tumor grades. There was also no detectable relation with tumor proliferative activity which was assessed by Ki67 immunostaining.

\section{$\underline{\text { SOX2 amplification }}$}

Sox2 amplification is characteristic for squamous cell carcinoma (SCC) pathogenesis and this can be correlated with the fact that lung SCC, similar to SCC from other organs, typically has a $3 \mathrm{q}$ overrepresentation/amplification. In contrast, adenocarcinomas of the lung harbor much less SOX2 amplifications (Karachaliou 2013). It should also be noted that alterations of chromosome 3 , in particular $3 p$ deletions being frequently associated with $3 q$ gains, are considered early events in head and neck as well as lung carcinogenesis (Bockmühl et al. 1996 ; Petersen et al. 1997). 
Interestingly, it has been shown that SOX2 and PIK3CA, both located at 3q26q28 and generally coamplified in lung SCC; cooperate in the transition of lung dysplasia into cancer (Kim et al. 2016).

It was also reported that SOX2 regulates cell cycle-related genes positively or negatively. CDKN1A, which induces G1 arrest, is repressed by SOX2 in lung carcinoma cells, pancreatic cancer cells (Chen et al., 2012) and gastric cancer cells (Otsubo et al. 2008). CDKN1B, which also induces G1 arrest, is repressed by SOX2 in pancreatic cancer cells and gastric cancer cells. CCND1, which accelerates the cell cycle, is activated by SOX2 in gastric cancer cells and MCF7 breast cancer cells (Chen et al. 2008) SOX2 represses cell cycle inhibitors and activates cell cycle accelerators; however, the pattern of gene regulation is not universal in different cancer cell types.

In squamous cell lung carcinoma, SOX2 amplifications were reported in $27 \%$ of cases being correlated with SOX2 expression. Inhibition of SOX2 protein expression by transfection of short hairpin RNA in SCLC cell lines with SOX2 expression resulted in reduced cell proliferation. In addition, it was mentioned that induction of SOX2 in lung epithelial cells increased the number of neural progenitor cells (Rudin et al. 2012).

According to a study carried out by Gut et al. (2018) based on 55 squamous cell carcinomas of the vulva, SOX2 amplification was found in $20.8 \% ; 27.3 \%$ of vulvar carcinomas showed SOX2 protein overexpression. SOX2 amplification was correlated with SOX2 overexpression in their data set $(\mathrm{P}<0.01)$. Amplification of the SOX2 locus was associated with high tumor grade $(\mathrm{P}<0.05)$ and human papillomavirus (HPV) positivity $(\mathrm{P}<0.01)$. SOX2-amplified tumors showed more frequently a basaloid phenotype than nonamplified carcinomas. SOX2 protein overexpression was also correlated with basaloid phenotype and positive HPV status of vulvar carcinomas.

\section{SOX2 regulation and its interplay with SSX-SS18, H3K27me3 and signaling}

\section{pathways}

In squamous lung and esophageal cancers, aberrant SOX2 expression was linked to the genomic amplification of its chromosomal location on chromosome 3q26.33. Chromosome $3 \mathrm{q}$ copy number gains are a common event in breast cancers and have 
been implicated as an independent predictor of poor prognosis in node-negative breast cancers (Janssen et al. 2003)

Therefore some of the positive SOX2 synovial sarcoma cases were further subjected to a molecular study via FISH to detect amplification on the genetic level, but all were negative. None of the positive cases revealed an amplification, thus gene copy number alterations do not seem to play a role in SOX2 upregulation in this tumor entity (Zayed and Petersen 2018).

Our results were consistent with Lengerke and colleagues (2011) who analyzed lymph node metastases of breast cancer to explore whether aberrant SOX2 expression is a result of gene amplification as reported in other carcinomas. With the exception of one case of low level amplification in a score 3 primary tumor, the majority of analyzed samples did not show SOX2 gene amplifications, suggesting that at least in breast carcinomas expressing SOX2, the aberrant gene expression is mostly driven by other mechanisms.

Different studies were conducted in attempt to understand the SOX2 overexpression mechanism and associated genetic alterations. In 2013, the interplay between SS18-SSX fusion, histone modification and SOX2 expression was highlighted by Kadoch and Crabtree (2013). They reported that the SS18-SSX fusion protein of synovial sarcoma leads to alterations in the human SWI/SNF chromatin remodeling complex. Similar to SS18, the fusion protein incorporates into the SWI/SNF complex resulting in the exclusion of the tumor suppressor gene BAF47 (also known as INI1 and SMARCB1), another component of the complex, resulting in its inactivation. The SWI/SNF complex antagonizes the activity of the Polycomb repressive complex 2 (PRC2) being responsible for trimethylation of lysine 27 of histone H3 (HeK27me3) by the methyltransferase EZH2 forming an essential component of the PRC2 complex and being considered a repressive mark for gene transcription (Kadoch et al. 2016). This was actually the reason why we considered analyzing global HeK27me3 expression in our synovial sarcoma cases.

The statistical analysis revealed a high statistically significant correlation between SOX2 and H3K27me3 expression ( $<<0.0005$, Chi square test). Out of 35 
SOX2 positive synovial sarcoma cases, 25 (71, 4\%) were HeK27me3 positive and 10 (28, 6\%) were negative (Zayed and Petersen 2018). Kadoch and Crabtree also reported that the altered SWI/SNF complex in synovial sarcoma binds to SOX2 gene locus resulting in SOX2 activation by a local decrease in $\mathrm{H} 3 \mathrm{~K} 27 \mathrm{me} 3$. This situation may be similar to seminoma in which a repressive $\mathrm{H} 3 \mathrm{~K} 27 \mathrm{me} 3$ mark at the SOX2 locus is responsible for SOX2 repression while there seems to be $\mathrm{H} 3 \mathrm{~K} 27 \mathrm{me} 3$ expression at least in a subset of neoplasms of this entity (Kushwaha et al. 2016; Kristensen et al. 2012).

Surface and colleagues (2010) reported that methylation of Histone H3 at the lysine 27 residue is mediated by the histone methyltransferase EZH2. Enhancer of zeste homologue 2 (EZH2) showed high expression in cells possessing embryonic gene expression signature, while its amount declines with tissue maturation and differentiation. Abnormal overexpression of EZH2 has been reported in a wide variety of tumor types including carcinomas, lymphomas, cutaneous melanoma, and soft tissue sarcomas (Chang and Hung 2012).

Kimura and colleagues (2016) also explored specific markers and discovered that synovial sarcoma cell lines possessed heterogeneity by way of containing a sphereforming subpopulation highly expressing Nanog, Oct4 and SOX2. By expression microarray analysis, CXCR4 was identified to be highly expressed in the sphere subpopulation and correlated with stem-cell associated markers. According to their study, stem-cell associated markers including SOX2 and SS18/SSX were highly expressed in the sphere/forming population of synovial sarcoma, hence SS18/SSX and its sphere-specific binding proteins might regulate tumor-initiating cells via epigenetic and/or transcriptional deregulation.

Generally, the impact of $\mathrm{H} 3 \mathrm{~K} 27 \mathrm{me} 27$ expression on cancer prognosis seems to be complex as there are also many studies reporting a better outcome in tumors with high expression, e.g. in colorectal and breast cancer (Bae et al. 2014; Benard et al. 2014). 


\section{$\underline{\text { Tumor progression of synovial sarcoma }}$}

In synovial sarcoma, endogenous EZH2 expression correlated with H3K27me3 at PcG target genes. It has been reported that high expression of EZH2 and H3K27me3 helps to distinguish poorly differentiated synovial sarcoma from monophasic and biphasic subtypes and is associated with unfavorable clinical outcome (Changchien et al. 2012). However our study does not provide such evidence, but it is important to mention the limitation of our tumor collective lacking data on metastatic spread and survival.

Metastasis and tumor progression in synovial sarcoma seem to be driven not only by epigenetic modifications like histone methylation but also additional chromosomal changes apart from the defining $\mathrm{t}(\mathrm{X} ; 18)(\mathrm{p} 11.2 ; \mathrm{q} 11.2)$ translocation and the activation of other genes and pathways distinct from the SS18-SSX gene fusion event (de Necochea-Campion et al. 2017). The CINSARC signature of 67 genes correlating with chromosomal instability and prognosis in undifferentiated sarcoma was also highly significant in stratifying synovial sarcoma with respect to metastatic outcome (Lagarde et al. 2013).

\section{$\underline{\text { Future sarcoma diagnostics }}$}

Recent studies assure the inevitable importance of understanding tumors' specific genetic mutations and utilizing this aspect in diagnostic measures as well as future elaborated gene based therapeutic regimes. For example in our study we clearly demonstrated the importance of the SS18-SSX gene fusion and its downstream targets SOX2 and H3K27me3 in synovial sarcoma. The entity provides a paradigm of a tumor that is primarily driven by alterations in the epigenome. The strength of the SS18-SSX alteration lies in the fact that the fusion gene has influence on two major players in epigenetic regulation. This leads to the inactivation of tumor suppressive functions of the SWI/SNF nucleosome remodeling complex and changes Histone chromatin marks that leads to the activation of the cancer stem cell transcription factor SOX2 as well as other genes that are normally suppressed by the polycomb repressive complexes 1 and 2 (Banito et al. 2018). 
In a study conducted by Koelsche and colleagues (2018) they stated that undifferentiated solid tumors with small blue round cell histology and expression of CD99 mostly resemble Ewing sarcoma; however, this group of smal round cell tumors may also include other tumors such as mesenchymal chondrosarcoma, synovial sarcoma, or small cell osteosarcoma. They assured that definitive classification usually requires detection of entity-specific mutations. Hence they generated genome-wide DNA-methylation profiles of 30 small blue round cell tumors not otherwise specified: $14(47 \%)$ assigned to Ewing sarcoma, $6(20 \%)$ to small blue round cell tumors with CIC alteration, 4 (13\%) to small blue round cell tumors with BCOR alteration, which is a methylation group composed of small blue round cell tumors with BCOR-CCNB3 fusion and clear cell sarcoma of the kidney with BCOR internal tandem duplication, two $(7 \%)$ to synovial sarcomas, two $(7 \%)$ to malignant rhabdoid tumors, and one $(3 \%)$ to mesenchymal chondrosarcomas. They also assured that genetic analyses validated the predicted sarcoma subtypes in most cases.

It is important to note that synovial sarcoma is characterized by a recurrent pattern of DNA methylation that can be used to separate and diagnose this entity against 50 other soft tissue tumor types using genome-wide methylation analysis and bioinformatical classification algorithms. The methylome analysis provides in addition a global gene copy profile which may help to establish prognostic subgroups of this entity (Petersen 2017; Köelsche et al. 2015). 


\section{CONCLUSION}

Our study proved a significant SOX2-expression in about $60 \%$ of the 60 synovial sarcoma cases investigated, whereas other soft tissue tumor entities showed very sporadic insignificant expression in only 13 out of 343 variable tumors.

Alongside our findings support other studies reporting SOX2 and H3K27me3 expression in synovial sarcoma which reveals that both biomarkers are related to each other.

This fact strengthens the notion that the tumor type is driven by epigenetic processes similar to those that are operating in pluripotent stem cells. The relevance of these parameters in the pathway pathology of synovial sarcoma, i.e. the timing and dosing of SOX2 and H3K27me3 expression initiated by the SS18-SSX driver mutation together with the interplay of these events with other signaling pathways, cellular mechanisms and additional mutations in tumor progression, will require further studies. 


\section{REFERENCES}

Abad M, Mosteiro L, Pantoja C, Cañamero M, Rayon T, Ors I, Graña O, Megías D, Domínguez O, Martínez D, Manzanares $M$, Ortega S, Serrano M. Reprogramming in vivo produces teratomas and iPS cells with totipotency features. Nature. 2013 Oct 17;502(7471):340-5. doi: 10.1038/nature12586. Epub 2013 Sep 11. PubMed PMID: 24025773.

Abd El-Maqsoud NM, Abd El-Rehim DM. Clinicopathologic implications of EpCAM and Sox 2 expression in breast cancer. Clin Breast Cancer. 2014 Feb;14(1):e19. doi: 10.1016/j.clbc.2013.09.006. Epub 2013 Sep 27. PubMed PMID: 24201161.

Al-Hajj M, Wicha MS, Benito-Hernandez A, Morrison SJ, Clarke MF. Prospective identification of tumorigenic breast cancer cells. Proc Natl Acad Sci U S A. 2003 Apr 1;100(7):3983-8. Epub 2003 Mar 10. Erratum in: Proc Natl Acad Sci U S A. 2003 May 27;100(11):6890. PubMed PMID: 12629218; PubMed Central PMCID: PMC153034.

Alonso MM, Diez-Valle R, Manterola L, Rubio A, Liu D, Cortes-Santiago N, Urquiza L, Jauregi P, Lopez de Munain A, Sampron N, Aramburu A, Tejada-Solís S, Vicente C, Odero MD, Bandrés E, García-Foncillas J, Idoate MA, Lang FF, Fueyo J, Gomez-Manzano C. Genetic and epigenetic modifications of Sox2 contribute to the invasive phenotype of malignant gliomas. PLoS One. 2011;6(11):e26740. doi: 10.1371/journal.pone.0026740. Epub 2011 Nov 1. PubMed PMID: 22069467; PubMed Central PMCID: PMC3206066.

Amary MF, Berisha F, Bernardi Fdel C, Herbert A, James M, Reis-Filho JS, Fisher C, Nicholson AG, Tirabosco R, Diss TC, Flanagan AM. Detection of SS18-SSX fusion transcripts in formalin-fixed paraffin-embedded neoplasms: analysis of conventional RT-PCR, qRT-PCR and dual color FISH as diagnostic tools for synovial sarcoma. Mod Pathol. 2007 Apr;20(4):482-96. Epub 2007 Mar 2. PubMed PMID:17334349.

Antonescu CR. The role of genetic testing in soft tissue sarcoma. Histopathology. 2006 Jan;48(1):13-21. Review. PubMed PMID: 16359533.

Avior Y, Biancotti JC, Benvenisty N. TeratoScore: Assessing the Differentiation Potential of Human Pluripotent Stem Cells by Quantitative Expression Analysis of Teratomas. Stem Cell Reports. 2015 Jun 9;4(6):967-74. doi: 10.1016/j.stemcr.2015.05.006. PubMed PMID: 26070610; PubMed Central PMCID: PMC4471824.

Bae WK, Yoo KH, Lee JS, Kim Y, Chung IJ, Park MH, Yoon JH, Furth PA, Hennighausen L. The methyltransferase EZH2 is not required for mammary cancer development, although high EZH2 and low H3K27me3 correlate with poor prognosis of ER-positive breast cancers. Mol Carcinog. 2015 Oct;54(10):1172-80. Doi: 10.1002/mc.22188. Epub 2014 Jul 7. PubMed PMID: 25043748; PubMed Central PMCID: PMC4286524. 
Banito A, Li X, Laporte AN, Roe JS, Sanchez-Vega F, Huang CH, Dancsok AR, Hatzi $\mathrm{K}$, Chen CC, Tschaharganeh DF, Chandwani R, Tasdemir N, Jones KB, Capecchi MR, Vakoc CR, Schultz N, Ladanyi M, Nielsen TO, Lowe SW. The SS18-SSX Oncoprotein Hijacks KDM2B-PRC1.1 to Drive Synovial Sarcoma. Cancer Cell. 2018 Feb 22. pii: S1535-6108(18)30018-7. doi: 10.1016/j.ccell.2018.01.018. [Epub ahead of print] PubMed PMID: 29502955.

Bass AJ, Watanabe H, Mermel CH, Yu S, Perner S, Verhaak RG, Kim SY, Wardwell L, Tamayo P, Gat-Viks I, Ramos AH, Woo MS, Weir BA, Getz G, Beroukhim R, O'Kelly M, Dutt A, Rozenblatt-Rosen O, Dziunycz P, Komisarof J, Chirieac LR, Lafargue CJ, Scheble V, Wilbertz T, Ma C, Rao S, Nakagawa H, Stairs DB, Lin L, Giordano TJ, Wagner P, Minna JD, Gazdar AF, Zhu CQ, Brose MS, Cecconello I, Ribeiro U Jr, Marie SK, Dahl O, Shivdasani RA, Tsao MS, Rubin MA, Wong KK, Regev A, Hahn WC, Beer DG, Rustgi AK, Meyerson $\mathrm{M}$. SOX2 is an amplified lineage-survival oncogene in lung and esophageal squamous cell carcinomas. Nat Genet. 2009 Nov;41(11):1238-42. doi: 10.1038/ng.465. Epub 2009 Oct 4. PubMed PMID: 19801978; PubMed Central PMCID: PMC2783775.

Beahrs OH, Henson DE, Hutter RVP, Kennedy BJ. Manual for staging of cancer, ed 4. Philadelphia, 1992, JB Lippincott Co.

Benard A, Goossens-Beumer IJ, van Hoesel AQ, Horati H, Putter H, Zeestraten EC, van de Velde CJ, Kuppen PJ. Prognostic value of polycomb proteins EZH2, BMI1 and SUZ12 and histone modification H3K27me3 in colorectal cancer. PLoS One. 2014 Sep 22;9(9):e108265. doi: 10.1371/journal.pone.0108265. eCollection 2014. PubMed PMID: 25243792; PubMed Central PMCID: PMC4171510.

Ben-Porath I, Thomson MW, Carey VJ, Ge R, Bell GW, Regev A, Weinberg RA. An embryonic stem cell-like gene expression signature in poorly differentiated aggressive human tumors. Nat Genet. 2008 May;40(5):499-507. doi: 10.1038/ng.127. PubMed PMID: 18443585; PubMed Central PMCID: PMC2912221.

Bergh P, Meis-Kindblom JM, Gherlinzoni F, Berlin O, Bacchini P, Bertoni F, Gunterberg B, Kindblom LG. Synovial sarcoma: identification of low and high risk groups. Cancer. 1999 Jun 15;85(12):2596-607. PubMed PMID: 10375108.

Bertazzi PA, Consonni D, Bachetti S, Rubagotti M, Baccarelli A, Zocchetti C, Pesatori AC. Health effects of dioxin exposure: a 20-year mortality study. Am J Epidemiol. 2001 Jun 1;153(11):1031-44. Review. PubMed PMID: 11390319.

Bertz J, Dahm S et al (2010) Verbreitung von Krebserkrankungen in DeutschlandEntwicklung der Prävalenzen zwischen 1990 und 2010. Robert Koch-Institut, Berlin. 
Billings SD, McKenney JK, Folpe AL, Hardacre MC, Weiss SW. Cutaneous angiosarcoma following breast-conserving surgery and radiation: an analysis of 27 cases. Am J Surg Pathol. 2004 Jun;28(6):781-8. PubMed PMID: 15166670.

Blanpain C, Fuchs E. Epidermal homeostasis: a balancing act of stem cells in the skin. Nat Rev Mol Cell Biol. 2009 Mar;10(3):207-17. doi: 10.1038/nrm2636.

Bockmühl U, Schwendel A, Dietel M, Petersen I. Distinct patterns of chromosomal alterations in high- and low-grade head and neck squamous cell carcinomas. Cancer Res. 1996 Dec 1;56(23):5325-9. PubMed PMID: 8968077.

Boyer LA, Lee TI, Cole MF, Johnstone SE, Levine SS, Zucker JP, Guenther MG, Kumar RM, Murray HL, Jenner RG, Gifford DK, Melton DA, Jaenisch R, Young RA. Core transcriptional regulatory circuitry in human embryonic stem cells. Cell. 2005 Sep 23;122(6):947-56. PubMed PMID: 16153702; PubMed Central PMCID: PMC3006442.

Brambrink T, Foreman R, Welstead GG, Lengner CJ, Wernig M, Suh H, Jaenisch R. Sequential expression of pluripotency markers during direct reprogramming of mouse somatic cells. Cell Stem Cell. 2008 Feb 7;2(2):151-9. doi:10.1016/j.stem.2008.01.004. PubMed PMID: 18371436; PubMed Central PMCID:PMC2276627.

Byrne JA, Pedersen DA, Clepper LL, Nelson M, Sanger WG, Gokhale S, Wolf DP, Mitalipov SM. Producing primate embryonic stem cells by somatic cell nuclear transfer. Nature. 2007 Nov 22;450(7169):497-502. Epub 2007 Nov 14. Erratum in: Nature. 2014 Dec 11;516(7530):276. PubMed PMID: 18004281.

Chan JA, McMenamin ME, Fletcher CD. Synovial sarcoma in older patients: clinicopathological analysis of 32 cases with emphasis on unusual histological features. Histopathology. 2003 Jul;43(1):72-83. PubMed PMID: 12823715.

Chang CC, Shidham VB. Molecular genetics of pediatric soft tissue tumors: clinical application. J Mol Diagn. 2003 Aug;5(3):143-54. Review. PubMed PMID: 12876204; PubMed Central PMCID: PMC1907327.

Chang CJ, Hung MC. The role of EZH2 in tumour progression. Br J Cancer. 2012 Jan 17;106(2):243-7. doi: 10.1038/bjc.2011.551. Epub 2011 Dec 20. Review. PubMed PMID: 22187039; PubMed Central PMCID: PMC3261672.

Changchien YC, Tátrai P, Papp G, Sápi J, Fónyad L, Szendrői M, Pápai Z, Sápi . Poorly differentiated synovial sarcoma is associated with high expression of enhancer of zeste homologue 2 (EZH2). J Transl Med. 2012 Oct 30;10:216. doi: 10.1186/1479-5876-10-216. PubMed PMID: 23110793; PubMed Central PMCID: PMC3494513.

Chen L, Daley GQ. Molecular basis of pluripotency. Hum Mol Genet. 2008 Apr 15;17(R1):R23-7. doi: 10.1093/hmg/ddn050. Review. PubMed PMID: 18632692 . 
Chen S, Li X, Lu D, Xu Y, Mou W, Wang L, Chen Y, Liu Y, Li X, Li LY, Liu L, Stupack D, Reisfeld RA, Xiang R, Li N. SOX2 regulates apoptosis through MAP4K4-survivin signaling pathway in human lung cancer cells. Carcinogenesis. 2014 Mar;35(3):613-23. doi: 10.1093/carcin/bgt371. Epub 2013 Nov 14. PubMed PMID: 24233838.

Chen S. et al. SOX2 gene regulates the transcriptional network of oncogenes and affects tumorigenesis of human lung cancer cells. PloS One. 7, e36326 (2012).

Chen Y. et al. The molecular mechanism governing the oncogenic potential of SOX2 in breast cancer. J Biol Chem. 283, 17969-17978 (2008).

Chiou SH, Wang ML, Chou YT, Chen CJ, Hong CF, Hsieh WJ, Chang HT, Chen YS, Lin TW, Hsu HS, Wu CW. Coexpression of Oct4 and Nanog enhances malignancy in lung adenocarcinoma by inducing cancer stem cell-like properties and epithelial-mesenchymal transdifferentiation. Cancer Res. 2010 Dec 15;70(24):10433-44. doi: 10.1158/0008-5472.CAN-10-2638. PubMed PMID: 21159654.

Chiou SH, Yu CC, Huang CY, Lin SC, Liu CJ, Tsai TH, Chou SH, Chien CS, Ku HH, Lo JF. Positive correlations of Oct-4 and Nanog in oral cancer stem-like cells and high-grade oral squamous cell carcinoma. Clin Cancer Res. $2008 \mathrm{Jul}$ 1;14(13):4085-95. doi: 10.1158/1078-0432.CCR-07-4404. PubMed PMID: 18593985.

Coindre JM, Nguyen BB, Bonichon F, de Mascarel I, Trojani M. Histopathologic grading in spindle cell soft tissue sarcomas. Cancer. 1988 Jun 1;61(11):2305-9. PubMed PMID: 3365658.

Coindre JM, Terrier P, Guillou L, Le Doussal V, Collin F, Ranchère D, Sastre X, Vilain MO, Bonichon F, N'Guyen Bui B. Predictive value of grade for metastasis development in the main histologic types of adult soft tissue sarcomas: a study of 1240 patients from the French Federation of Cancer Centers Sarcoma Group. Cancer. 2001 May 15;91(10):1914-26. PubMed PMID: 11346874.

Collignon J, Sockanathan S, Hacker A, Cohen-Tannoudji M, Norris D, Rastan S, Stevanovic M, Goodfellow PN, Lovell-Badge R. A comparison of the properties of Sox-3 with Sry and two related genes, Sox-1 and Sox-2. Development. 1996 Feb;122(2):509-20. PubMed PMID: 8625802.

Collins JJ, Bodner K, Aylward LL, Wilken M, Swaen G, Budinsky R, Rowlands C, Bodnar CM. Mortality rates among workers exposed to dioxins in the manufacture of pentachlorophenol. J Occup Environ Med. 2009 Oct;51(10):1212-9. doi: 10.1097/JOM.0b013e3181badd4e. PubMed PMID: 19786897.

Curry EL, Moad M, Robson CN, Heer R. Using induced pluripotent stem cells as a tool for modelling carcinogenesis. World J Stem Cells. 2015 Mar 26;7(2):461-9. 
doi: 10.4252/wjsc.v7.i2.461. Review. PubMed PMID: 25815129; PubMed Central PMCID: PMC4369501.

Dalerba P, Cho RW, Clarke MF. Cancer stem cells: models and concepts. Annu Rev Med. 2007;58:267-84. Review. PubMed PMID: 17002552.

Dawlatly SL, Dramis A, Sumathi VP, Grimer RJ. Stewart-Treves syndrome and the use of positron emission tomographic scanning. Ann Vasc Surg. 2011 Jul;25(5):699.e1-3. doi: 10.1016/j.avsg.2010.12.027. Epub 2011 Apr 21. PubMed PMID: 21514109.

Dawson MA, Kouzarides T. Cancer epigenetics: from mechanism to therapy. Cell. 2012 Jul 6;150(1):12-27. doi: 10.1016/j.cell.2012.06.013. Review. PubMed PMID:22770212.

de Necochea-Campion R, Zuckerman LM, Mirshahidi HR, Khosrowpour S, Chen CS, Mirshahidi S. Metastatic biomarkers in synovial sarcoma. Biomark Res. 2017 Feb 7;5:4. doi: 10.1186/s40364-017-0083-x. eCollection 2017. Review. PubMed PMID: 28191313; PubMed Central PMCID: PMC5297148.

Deyrup AT, Lee VK, Hill CE, Cheuk W, Toh HC, Kesavan S, Chan EW, Weiss SW. Epstein-Barr virus-associated smooth muscle tumors are distinctive mesenchymal tumors reflecting multiple infection events: a clinicopathologic and molecular analysis of 29 tumors from 19 patients. Am J Surg Pathol. 2006 Jan;30(1):75-82. PubMed PMID: 16330945.

Deyrup AT, Weiss SW. Grading of soft tissue sarcomas: the challenge of providing precise information in an imprecise world. Histopathology. 2006 Jan;48(1):4250. Review. PubMed PMID: 16359536.

Engellau J, Bendahl PO, Persson A, Domanski HA, Akerman M, Gustafson P, Alvegård TA, Nilbert M, Rydholm A. Improved prognostication in soft tissue sarcoma: independent information from vascular invasion, necrosis, growth pattern, and immunostaining using whole-tumor sections and tissue microarrays. Hum Pathol. 2005 Sep;36(9):994-1002. PubMed PMID: 16153463.

Enjoji M, Hashimoto H. Diagnosis of soft tissue sarcomas. Pathol Res Pract. 1984 Jan;178(3):215-26. PubMed PMID: 6326068.

Epub 2009 Feb 11. Review. PubMed PMID: 19209183; PubMed Central PMCID: PMC2760218.

Fang WT, Fan CC, Li SM, Jang TH, Lin HP, Shih NY, Chen CH, Wang TY, Huang SF, Lee AY, Liu YL, Tsai FY, Huang CT, Yang SJ, Yen LJ, Chuu CP, Chen CY, Hsiung CA, Chang JY, Wang LH, Chang IS, Jiang SS. Downregulation of a putative tumor suppressor BMP4 by SOX2 promotes growth of lung squamous cell carcinoma. Int $J$ Cancer. 2014 Aug 15;135(4):809-19. doi: 10.1002/ijc.28734. Epub 2014 Jan 30. PubMed PMID: 24477565. 
Fang Z, Matsumoto S, Ae K, Kawaguchi N, Yoshikawa H, Ueda T, Ishii T, Araki N, Kito M. Postradiation soft tissue sarcoma: a multiinstitutional analysis of 14 cases in Japan. J Orthop Sci. 2004;9(3):242-6. PubMed PMID: 15168177.

Fearon ER, Hamilton SR, Vogelstein B. Clonal analysis of human colorectal tumors. Science. 1987 Oct 9;238(4824):193-7. PubMed PMID: 2889267.

Ferguson PC, Griffin AM, O'Sullivan B, Catton CN, Davis AM, Murji A, Bell RS, Wunder JS. Bone invasion in extremity soft-tissue sarcoma: impact on disease outcomes. Cancer. 2006 Jun 15;106(12):2692-700. PubMed PMID: 16700041.

Ferrari A, Sultan I, Huang TT, Rodriguez-Galindo C, Shehadeh A, Meazza C, Ness KK, Casanova M, Spunt SL. Soft tissue sarcoma across the age spectrum: a population-based study from the Surveillance Epidemiology and End Results database. Pediatr Blood Cancer. 2011 Dec 1;57(6):943-9. doi: 10.1002/pbc.23252. Epub 2011 Jul 25. PubMed PMID: 21793180; PubMed Central PMCID: PMC4261144.

Ferri AL, Cavallaro M, Braida D, Di Cristofano A, Canta A, Vezzani A, Ottolenghi S, Pandolfi PP, Sala M, DeBiasi S, Nicolis SK. Sox2 deficiency causes neurodegeneration and impaired neurogenesis in the adult mouse brain. Development. 2004 Aug;131(15):3805-19. Epub 2004 Jul 7. PubMed PMID: 15240551.

Fetsch JF, Meis JM. Synovial sarcoma of the abdominal wall. Cancer. 1993 Jul 15;72(2):469-77. PubMed PMID: 8391380.

Fisher C, Folpe AL, Hashimoto H, Weiss SW. Intra-abdominal synovial sarcoma: a clinicopathological study. Histopathology. 2004 Sep;45(3):245-53. PubMed PMID:15330802.

Fletcher C, Bridge JA, Hogendoorn PC, Mertens F. 2013. WHO Classification of Tumours of Soft Tissue and Bone. Lyon: IARC Press.

Fletcher CD. The evolving classification of soft tissue tumors: an update based on the new WHO classification. Histopathology 2006, 48: 3-12

Fletcher CDM, Krishnan Unni K, Mertens F. Pathology and genetics of tumors of soft tissue and bone. Lyon: IARC Press; 2002.

Gerrand CH, Wunder JS, Kandel RA, O'Sullivan B, Catton CN, Bell RS, Griffin AM, Davis AM. The influence of anatomic location on functional outcome in lowerextremity soft-tissue sarcoma. Ann Surg Oncol. 2004 May;11(5):476-82. Epub 2004 Apr 12. PubMed PMID: 15078635.

Girouard SD, Laga AC, Mihm MC, Scolyer RA, Thompson JF, Zhan Q, Widlund HR, Lee CW, Murphy GF. SOX2 contributes to melanoma cell invasion. Lab Invest. 2012 Mar;92(3):362-70. doi: 10.1038/labinvest.2011.188. Epub 2011 Dec 19. PubMed PMID: 22184093; PubMed Central PMCID: PMC3887365. 
GoldblumJohn R, Weiss Sharon W., Folpe Andrew L (2014). Enzinger and Weiss's Soft Tissue Tumors. N.p.:Elsevier Health sciences. Pgs 1-10

Graham V, Khudyakov J, Ellis P, Pevny L. SOX2 functions to maintain neural progenitor identity. Neuron. 2003 Aug 28;39(5):749-65. PubMed PMID: 12948443.

Grobmyer SR, Luther N, Antonescu CR, Singer S, Brennan MF. Multiple primary soft tissue sarcomas. Cancer. 2004 Dec 1;101(11):2633-5. PubMed PMID: 15494976.

Guo G, Yang J, Nichols J, Hall JS, Eyres I, Mansfield W, Smith A. Klf4 reverts developmentally programmed restriction of ground state pluripotency. Development. 2009 Apr;136(7):1063-9. doi: 10.1242/dev.030957. Epub 2009 Feb 18. PubMed PMID:19224983; PubMed Central PMCID: PMC2685927.

Guo Y, Liu S, Wang P, Zhao S, Wang F, Bing L, Zhang Y, Ling EA, Gao J, Hao A. Expression profile of embryonic stem cell-associated genes Oct4, Sox2 and Nanog in human gliomas. Histopathology. 2011 Oct;59(4):763-75. doi:10.1111/j.1365-2559.2011.03993.x. PubMed PMID: 22014056.

Gut A, Moch H, Choschzick M. SOX2 Gene Amplification and Overexpression is Linked to HPV-positive Vulvar Carcinomas. Int J Gynecol Pathol. 2018 Jan;37(1):68-73. doi: 10.1097/PGP.0000000000000388. PubMed PMID: 28700423.

Gutierrez-Aranda I, Ramos-Mejia V, Bueno C, Munoz-Lopez M, Real PJ, Mácia A, Sanchez L, Ligero G, Garcia-Parez JL, Menendez P. Human induced pluripotent stem cells develop teratoma more efficiently and faster than human embryonic stem cells regardless the site of injection. Stem Cells. 2010 Sep;28(9):1568-70. doi: 10.1002/stem.471. PubMed PMID: 20641038; PubMed Central PMCID: PMC2996086.

Han X, Fang X, Lou X, Hua D, Ding W, Foltz G, Hood L, Yuan Y, Lin B. Silencing SOX2 induced mesenchymal-epithelial transition and its expression predicts liver and lymph node metastasis of CRC patients. PLoS One. 2012;7(8):e41335. doi: 10.1371/journal.pone.0041335. Epub 2012 Aug 17. PubMed PMID: 22912670; PubMed Central PMCID: PMC3422347.

Hanahan D, Weinberg RA. Hallmarks of cancer: the next generation. Cell. 2011 Mar 4;144(5):646-74. doi: 10.1016/j.cell.2011.02.013. Review. PubMed PMID: 21376230 .

Hardell L, Eriksson M, Axelson O. Agent Orange in war medicine: an aftermath myth. Int J Health Serv. 1998;28(4):715-24. Review. PubMed PMID: 9842495.

Hasegawa T. Histological grading and MIB-1 labeling index of soft-tissue sarcomas. Pathol Int. 2007 Mar;57(3):121-5. Review. PubMed PMID: 17295643. 
Heim-Hall J, Yohe SL. Application of immunohistochemistry to soft tissue neoplasms. Arch Pathol Lab Med. 2008 Mar;132(3):476-89. doi:10.1043/15432165(2008)132[476:AOITST]2.0.CO;2. Review. PubMed PMID: 18318588.

Herreros-Villanueva M, Zhang JS, Koenig A, Abel EV, Smyrk TC, Bamlet WR, de Narvajas AA, Gomez TS, Simeone DM, Bujanda L, Billadeau DD. SOX2 promotes dedifferentiation and imparts stem cell-like features to pancreatic cancer cells. Oncogenesis. 2013 Aug 5;2:e61. doi: 10.1038/oncsis.2013.23. PubMed PMID: 23917223; PubMed Central PMCID: PMC3759123.

Hill RP, Perris R. "Destemming" cancer stem cells. J Natl Cancer Inst. 2007 Oct 3;99(19):1435-40. Epub 2007 Sep 25. Review. PubMed PMID: 17895479.

Ho L, Miller EL, Ronan JL, Ho WQ, Jothi R, Crabtree GR. esBAF facilitates pluripotency by conditioning the genome for LIF/STAT3 signalling and by regulating polycomb function. Nat Cell Biol. 2011 Jul 24;13(8):903-13. doi: 10.1038/ncb2285. PubMed PMID: 21785422; PubMed Central PMCID: PMC3155811.

Huangfu D, Maehr R, Guo W, Eijkelenboom A, Snitow M, Chen AE, Melton DA. Induction of pluripotent stem cells by defined factors is greatly improved by small-molecule compounds. Nat Biotechnol. 2008 Jul;26(7):795-7. doi: 10.1038/nbt1418. Epub 2008 Jun 22. PubMed PMID: 18568017.

Inoue YZ, Frassica FJ, Sim FH, Unni KK, Petersen IA, McLeod RA. Clinicopathologic features and treatment of postirradiation sarcoma of bone and soft tissue. J Surg Oncol. 2000 Sep;75(1):42-50. PubMed PMID: 11025461.

Iwasaki H, Nabeshima K, Nishio J, Jimi S, Aoki M, Koga K, Hamasaki M, Hayashi H, Mogi A. Pathology of soft-tissue tumors: daily diagnosis, molecular cytogenetics and experimental approach. Pathol Int. 2009 Aug;59(8):501-21. doi: 10.1111/j.1440-1827.2009.02401.x. Review. Erratum in: Pathol Int. 2009 Dec;59(12):900. PubMed PMID: 19627534.

Janssen EA, Baak JP, Guervós MA, van Diest PJ, Jiwa M, Hermsen MA. In lymph node-negative invasive breast carcinomas, specific chromosomal aberrations are strongly associated with high mitotic activity and predict outcome more accurately than grade, tumour diameter, and oestrogen receptor. J Pathol. 2003 Dec;201(4):555-61. PubMed PMID: 14648658.

Jia X, Li X, Xu Y, Zhang S, Mou W, Liu Y, Liu Y, Lv D, Liu CH, Tan X, Xiang R, Li N. SOX2 promotes tumorigenesis and increases the anti-apoptotic property of human prostate cancer cell. J Mol Cell Biol. 2011 Aug;3(4):230-8. doi: 10.1093/jmcb/mjr002. Epub 2011 Mar 17. PubMed PMID: 21415100.

Johansson H, Simonsson S. Core transcription factors, Oct4, Sox2 and Nanog, individually form complexes with nucleophosmin (Npm1) to control embryonic stem (ES) cell fate determination. Aging (Albany NY). 2010 
Nov;2(11):815-22. PubMed PMID: 21076177; PubMed Central PMCID: PMC3006024.

Jordan CT, Guzman ML, Noble M. Cancer stem cells. N Engl J Med. 2006 Sep 21;355(12):1253-61. Review. PubMed PMID: 16990388.

Kadoch C, Copeland RA, Keilhack H. PRC2 and SWI/SNF Chromatin Remodeling Complexes in Health and Disease. Biochemistry. 2016 Mar 22;55(11):1600-14. doi: 10.1021/acs.biochem.5b01191. Epub 2016 Feb 17. Review. PubMed PMID: 26836503.

Kadoch C, Crabtree GR. Reversible disruption of mSWI/SNF (BAF) complexes by the SS18-SSX oncogenic fusion in synovial sarcoma. Cell. 2013 Mar 28;153(1):71-85. doi: 10.1016/j.cell.2013.02.036. PubMed PMID: 23540691; PubMed Central PMCID: PMC3655887.

Kadoch C, Hargreaves DC, Hodges C, Elias L, Ho L, Ranish J, Crabtree GR. Proteomic and bioinformatic analysis of mammalian SWI/SNF complexes identifies extensive roles in human malignancy. Nat Genet. 2013 Jun;45(6):592-601. doi:10.1038/ng.2628. Epub 2013 May 5. PubMed PMID: 23644491; PubMed Central PMCID: PMC3667980.

Kandoth C, Schultz N, Cherniack AD, Akbani R, Liu Y, Shen H, Robertson AG, Pashtan I, Shen R, Benz CC, Yau C, Laird PW, Ding L, Zhang W, Mills GB, Kucherlapati R, Mardis ER, Levine DA. Cancer Genome Atlas Research Network. Integrated genomic characterization of endometrial carcinoma. Nature. 2013 May 2;497(7447):67-73. doi: 10.1038/nature12113. Erratum in: Nature. 2013 Aug 8;500(7461):242. PubMed PMID: 23636398; PubMed Central PMCID: PMC3704730.

Karachaliou N, Rosell R, Viteri S. The role of SOX2 in small cell lung cancer, lung adenocarcinoma and squamous cell carcinoma of the lung. Transl Lung Cancer Res. 2013 Jun;2(3):172-9. doi: 10.3978/j.issn.2218-6751.2013.01.01. Review. PubMed PMID: 25806230; PubMed Central PMCID: PMC4367598.

Karachaliou N, Rosell R, Viteri S. The role of SOX2 in small cell lung cancer, lung adenocarcinoma and squamous cell carcinoma of the lung. Transl Lung Cancer Res. 2013 Jun;2(3):172-9. doi: 10.3978/j.issn.2218-6751.2013.01.01. Review. PubMed PMID: 25806230; PubMed Central PMCID: PMC4367598.

Kashyap V, Rezende NC, Scotland KB, Shaffer SM, Persson JL, Gudas LJ, Mongan NP. Regulation of stem cell pluripotency and differentiation involves a mutual regulatory circuit of the NANOG, OCT4, and SOX2 pluripotency transcription factors with polycomb repressive complexes and stem cell microRNAs. Stem Cells Dev. 2009 Sep;18(7):1093-108. doi: 10.1089/scd.2009.0113. Review. PubMed PMID: 19480567; PubMed Central PMCID: PMC3135180. 
Katenkamp D, Katenkamp K. [Modern morphological diagnosis and current classification of soft tissue sarcomas]. Chirurg. 2009 Mar;80(3):186-93. doi: 10.1007/s00104-008-1593-8. Review. German. PubMed PMID: 19172240.

Kauffman SL, Stout AP. Congenital Mesenchymal Tumors. Cancer. 1965 Apr;18:46076. PubMed PMID: 14278043.

Kawai A, Noguchi M, Beppu Y, Yokoyama R, Mukai K, Hirohashi S, Inoue H, Fukuma H. Nuclear immunoreaction of p53 protein in soft tissue sarcomas. A possible prognostic factor. Cancer. 1994 May 15;73(10):2499-505. PubMed PMID: 8174045.

Kim BR, Van de Laar E, Cabanero M, Tarumi S, Hasenoeder S, Wang D, Virtanen C, Suzuki T, Bandarchi B, Sakashita S, Pham NA, Lee S, Keshavjee S, Waddell TK, Tsao MS, Moghal N. SOX2 and PI3K Cooperate to Induce and Stabilize a Squamous-Committed Stem Cell Injury State during Lung Squamous Cell Carcinoma Pathogenesis. PLoS Biol. 2016 Nov 23;14(11):e1002581. Doi: 10.1371/journal.pbio.1002581. eCollection 2016 Nov. PubMed PMID: 27880766; PubMed Central PMCID: PMC5120804.

Kimura T, Wang L, Tabu K, Tsuda M, Tanino M, Maekawa A, Nishihara H, Hiraga H, Taga T, Oda Y, Tanaka S. Identification and analysis of CXCR4-positive synovial sarcoma-initiating cells. Oncogene. 2016 Jul 28;35(30):3932-43. doi: 10.1038/onc.2015.461. Epub 2015 Dec 7. PubMed PMID: 26640147.

Koelsche C, Hartmann W, Schrimpf D, Stichel D, Jabar S, Ranft A, Reuss DE, Sahm F, Jones DTW, Bewerunge-Hudler M, Trautmann M, Klingebiel T, Vokuhl C, Gessler M, Wardelmann E, Petersen I, Baumhoer D, Flucke U, Antonescu C, Esteller M, Fröhling S, Kool M, Pfister SM, Mechtersheimer G, Dirksen U, von Deimling A. Array-based DNA-methylation profiling in sarcomas with small blue round cell histology provides valuable diagnostic information. Mod Pathol. 2018 Mar 23. doi: 10.1038/s41379-018-0045-3. [Epub ahead of print] PubMed PMID: 29572501.

Köelsche C, Hovestadt V, Jones DT, Capper D, Sturm D, Sahm F, Schrimpf D, Adeberg S, Böhmer K, Hagenlocher C, Mechtersheimer G, Kohlhof P, Mühleisen H, Beschorner R, Hartmann C, Braczynski AK, Mittelbronn M, Buslei R, Becker A, Grote A, Urbach H, Staszewski O, Prinz M, Hewer E, Pfister SM, von Deimling A, Reuss DE. Melanotic tumors of the nervous system are characterized by distinct mutational, chromosomal and epigenomic profiles. Brain Pathol. 2015 Mar;25(2):202-8. doi: 10.1111/bpa.12228. Epub 2014 Dec 15. PubMed PMID: 25399693.

Kramárová E, Kogevinas M, Anh CT, Cau HD, Dai LC, Stellman SD, Parkin DM. Exposure to Agent Orange and occurrence of soft-tissue sarcomas or nonHodgkin lymphomas: an ongoing study in Vietnam. Environ Health Perspect. 1998 Apr;106 Suppl 2:671-8. PubMed PMID: 9599715; PubMed Central PMCID: PMC1533419. 
Kristensen DG, Mlynarska O, Nielsen JE, Jacobsen GK, Rajpert-De Meyts E, Almstrup K. Heterogeneity of chromatin modifications in testicular spermatocytic seminoma point toward an epigenetically unstable phenotype. Cancer Genet. 2012 Sep;205(9):425-31. doi: 10.1016/j.cancergen.2012.05.003. Epub 2012 Jul 21. PubMed PMID: 22819380.

Kroese MC, Rutgers DH, Wils IS, Van Unnik JA, Roholl PJ. The relevance of the DNA index and proliferation rate in the grading of benign and malignant soft tissue tumors. Cancer. 1990 Apr 15;65(8):1782-8. PubMed PMID: 2156603.

Kummermehr JC. Tumour stem cells--the evidence and the ambiguity. Acta Oncol. 2001;40(8):981-8. Review. PubMed PMID: 11845964.

Kushwaha R, Jagadish N, Kustagi M, Mendiratta G, Seandel M, Soni R, Korkola JE, Thodima V, Califano A, Bosl GJ, Chaganti RSK. Mechanism and Role of SOX2 Repression in Seminoma: Relevance to Human Germline Specification. Stem Cell Reports. 2016 May 10;6(5):772-783. doi: 10.1016/j.stemcr.2016.04.002. Epub 2016 Apr 28. PubMed PMID: 27132888; PubMed Central PMCID: PMC4939754.

Lagarde P, Przybyl J, Brulard C, Pérot G, Pierron G, Delattre O, Sciot R, Wozniak A, Schöffski P, Terrier P, Neuville A, Coindre JM, Italiano A, Orbach D, DebiecRychter M, Chibon F. Chromosome instability accounts for reverse metastatic outcomes of pediatric and adult synovial sarcomas. J Clin Oncol. 2013 Feb 10;31(5):608-15. doi: 10.1200/JCO.2012.46.0147. Epub 2013 Jan 14. PubMed PMID: 23319690.

Laskin WB, Silverman TA, Enzinger FM. Postradiation soft tissue sarcomas. An analysis of 53 cases. Cancer. 1988 Dec 1;62(11):2330-40. PubMed PMID: 3179948 .

Layfield LJ, Anders KH, Glasgow BJ, Mirra JM. Fine-needle aspiration of primary softtissue lesions. Arch Pathol Lab Med. 1986 May;110(5):420-4. PubMed PMID: 3754426 .

Lehnhardt M, Daigeler A, Homann HH, Hauser J, Langer S, Steinsträsser L, Soimaru C, Puls A, Steinau HU. [Importance of specialized centers in diagnosis and treatment of extremity-soft tissue sarcomas. Review of 603 cases]. Chirurg. 2009 Apr;80(4):341-7. doi: 10.1007/s00104-008-1562-2. German. PubMed PMID: 18523742.

Lengerke C, Fehm T, Kurth R, Neubauer H, Scheble V, Müller F, Schneider F, Petersen K, Wallwiener D, Kanz L, Fend F, Perner S, Bareiss PM, Staebler A. Expression of the embryonic stem cell marker SOX2 in early-stage breast carcinoma. BMC Cancer. 2011 Jan 28;11:42. doi: 10.1186/1471-2407-11-42. PubMed PMID: 21276239; PubMed Central PMCID: PMC3038979.

Lewis JJ, Antonescu CR, Leung DH, Blumberg D, Healey JH, Woodruff JM, Brennan MF. Synovial sarcoma: a multivariate analysis of prognostic factors in 112 
patients with primary localized tumors of the extremity. J Clin Oncol. 2000 May;18(10):2087-94. PubMed PMID: 10811674.

Lim J, Thiery JP. Epithelial-mesenchymal transitions: insights from development. Development. 2012 Oct;139(19):3471-86. doi: 10.1242/dev.071209. Review. PubMed PMID: 22949611.

Liu H, Du L, Wen Z, Yang Y, Li J, Dong Z, Zheng G, Wang L, Zhang X, Wang C. Sex determining region Y-box 2 inhibits the proliferation of colorectal adenocarcinoma cells through the mTOR signaling pathway. Int J Mol Med. 2013 Jul;32(1):59-66. doi: 10.3892/ijmm.2013.1354. Epub 2013 Apr 19. PubMed PMID: 23599173.

Lluis F, Pedone E, Pepe S, Cosma MP. Periodic activation of Wnt/beta-catenin signaling enhances somatic cell reprogramming mediated by cell fusion. Cell Stem Cell. 2008 Nov 6;3(5):493-507. doi: 10.1016/j.stem.2008.08.017. PubMed PMID: 18983965.

Loh YH, Wu Q, Chew JL, Vega VB, Zhang W, Chen X, Bourque G, George J, Leong B, Liu J, Wong KY, Sung KW, Lee CW, Zhao XD, Chiu KP, Lipovich L, Kuznetsov VA, Robson P, Stanton LW, Wei CL, Ruan Y, Lim B, Ng HH. The Oct4 and Nanog transcription network regulates pluripotency in mouse embryonic stem cells. Nat Genet. 2006 Apr;38(4):431-40. Epub 2006 Mar 5. PubMed PMID: 16518401.

Long KB, Hornick JL. SOX2 is highly expressed in squamous cell carcinomas of the gastrointestinal tract. Hum Pathol. 2009 Dec;40(12):1768-73. doi: 10.1016/j.humpath.2009.06.006. Epub 2009 Aug 27. PubMed PMID: 19716157.

Lou X, Han X, Jin C, Tian W, Yu W, Ding D, Cheng L, Huang B, Jiang H, Lin B. SOX2 targets fibronectin 1 to promote cell migration and invasion in ovarian cancer: new molecular leads for therapeutic intervention. OMICS. 2013 Oct;17(10):510-8. doi: 10.1089/omi.2013.0058. Epub 2013 Jul 29. PubMed PMID: 23895273; PubMed Central PMCID: PMC3783972.

Lu Y, Futtner C, Rock JR, Xu X, Whitworth W, Hogan BL, Onaitis MW. Evidence that SOX2 overexpression is oncogenic in the lung. PLoS One. 2010 Jun 10;5(6):e11022. doi: 10.1371/journal.pone.0011022. PubMed PMID: 20548776; PubMed Central PMCID: PMC2883553.

Luo W, Li S, Peng B, Ye Y, Deng X, Yao K. Embryonic stem cells markers SOX2, OCT4 and Nanog expression and their correlations with epithelialmesenchymal transition in nasopharyngeal carcinoma. PLoS One. 2013;8(2):e56324. doi:10.1371/journal.pone.0056324. Epub 2013 Feb 12. PubMed PMID: 23424657; PubMed Central PMCID: PMC3570418. 
Magnuson T, Epstein CJ, Silver LM, Martin GR. Pluripotent embryonic stem cell lines can be derived from tw5/tw5 blastocysts. Nature. 1982 Aug 19;298(5876):7503. PubMed PMID: 7110310.

Mark RJ, Poen JC, Tran LM, Fu YS, Juillard GF. Angiosarcoma. A report of 67 patients and a review of the literature. Cancer. 1996 Jun 1;77(11):2400-6. Review. PubMed PMID: 8635113.

Marte B. Tumour heterogeneity. Nature. 2013 Sep 19;501(7467):327. doi: 10.1038/501327a. PubMed PMID: 24048064.

Matsuoka J, Yashiro M, Sakurai K, Kubo N, Tanaka H, Muguruma K, Sawada T, Ohira M, Hirakawa K. Role of the stemness factors sox2, oct3/4, and nanog in gastric carcinoma. J Surg Res. 2012 May 1;174(1):130-5. doi:10.1016/j.jss.2010.11.903. Epub 2010 Dec 18. PubMed PMID: 21227461.

Mertens F, Antonescu CR, Mitelman F. Gene fusions in soft tissue tumors: Recurrent and overlapping pathogenetic themes. Genes Chromosomes Cancer. 2016 Apr;55(4):291-310. doi: 10.1002/gcc.22335. Epub 2015 Dec 18. Review. PubMed PMID:26684580; PubMed Central PMCID: PMC5012284.

Mesri EA, Cesarman E, Boshoff C. Kaposi's sarcoma and its associated herpesvirus. Nat Rev Cancer. 2010 Oct;10(10):707-19. doi: 10.1038/nrc2888. Review. PubMed PMID: 20865011; PubMed Central PMCID: PMC4721662.

Mills SE. Sometimes we don't look like our parents. Mod Pathol. 1995 May;8(4):347. PubMed PMID: 7567927.

Monkman GR, Orwoll G, Ivins JC. Trauma and oncogenesis. Mayo Clin Proc. 1974 Mar;49(3):157-63. PubMed PMID: 4273525.

Müller M, Hermann PC, Liebau S, Weidgang C, Seufferlein T, Kleger A, Perkhofer L. The role of pluripotency factors to drive stemness in gastrointestinal cancer. Stem Cell Res. 2016 Mar;16(2):349-57. doi: 10.1016/j.scr.2016.02.005. Epub 2016 Feb 3. Review. PubMed PMID: 26896855.

Müller M, Hermann PC, Liebau S, Weidgang C, Seufferlein T, Kleger A, Perkhofer L. The role of pluripotency factors to drive stemness in gastrointestinal cancer. Stem Cell Res. 2016 Mar;16(2):349-57. doi: 10.1016/j.scr.2016.02.005. Epub 2016 Feb 3. Review. PubMed PMID: 26896855.

Naka N, Takenaka S, Araki N, Miwa T, Hashimoto N, Yoshioka K, Joyama S, Hamada K, Tsukamoto Y, Tomita Y, Ueda T, Yoshikawa H, Itoh K. Synovial sarcoma is a stem cell malignancy. Stem Cells. 2010 Jul;28(7):1119-31. doi: 10.1002/stem.452. PubMed PMID: 20518020.

Nakagawa M, Koyanagi M, Tanabe K, Takahashi K, Ichisaka T, Aoi T, Okita K, Mochiduki Y, Takizawa N, Yamanaka S. Generation of induced pluripotent 
stem cells without Myc from mouse and human fibroblasts. Nat Biotechnol. 2008 Jan;26(1):101-6. Epub 2007 Nov 30. PubMed PMID: 18059259.

Neumann J, Bahr F, Horst D, Kriegl L, Engel J, Luque RM, Gerhard M, Kirchner T, Jung A. SOX2 expression correlates with lymph-node metastases and distant spread in right-sided colon cancer. BMC Cancer. 2011 Dec 14;11:518. doi: 10.1186/1471-2407-11-518. PubMed PMID: 22168803; PubMed Central PMCID: PMC3267776.

Nielsen TO, Poulin NM, Ladanyi M. Synovial sarcoma: recent discoveries as a roadmap to new avenues for therapy. Cancer Discov. 2015;5:124-134.

Nowell PC. Mechanisms of tumor progression. Cancer Res. 1986 May;46(5):2203-7. Review. PubMed PMID: 3516380.

Ohnishi K, Semi K, Yamamoto T, Shimizu M, Tanaka A, Mitsunaga K, Okita K, Osafune K, Arioka Y, Maeda T, Soejima H, Moriwaki H, Yamanaka S, Woltjen K, Yamada Y. Premature termination of reprogramming in vivo leads to cancer development through altered epigenetic regulation. Cell. $2014 \mathrm{Feb}$ 13;156(4):663-77. doi: 10.1016/j.cell.2014.01.005. PubMed PMID: 24529372.

Ohnishi K, Semi K, Yamamoto T, Shimizu M, Tanaka A, Mitsunaga K, Okita K, Osafune K, Arioka Y, Maeda T, Soejima H, Moriwaki H, Yamanaka S, Woltjen K, Yamada Y. Premature termination of reprogramming in vivo leads to cancer development through altered epigenetic regulation. Cell. $2014 \mathrm{Feb}$ 13;156(4):663-77. doi: 10.1016/j.cell.2014.01.005. PubMed PMID: 24529372.

Ordóñez NG. Application of immunocytochemistry in the diagnosis of soft tissue sarcomas: a review and update. Adv Anat Pathol. 1998 Mar;5(2):67-85. Review. PubMed PMID: 9868514.

Otsubo T., Akiyama Y., Yanagihara K. \& Yuasa Y. SOX2 is frequently downregulated in gastric cancers and inhibits cell growth through cell-cycle arrest and apoptosis. Br J Cancer. 98, 824-831 (2008).

Pelmus M, Guillou L, Hostein I, Sierankowski G, Lussan C, Coindre JM. Monophasic fibrous and poorly differentiated synovial sarcoma: immunohistochemical reassessment of $60 \mathrm{t}(\mathrm{X} ; 18)(\mathrm{SYT}-\mathrm{SSX})$-positive cases. Am J Surg Pathol. 2002 Nov;26(11):1434-40. PubMed PMID: 12409719.

Pelmus M, Guillou L, Hostein I, Sierankowski G, Lussan C, Coindre JM. Monophasic fibrous and poorly differentiated synovial sarcoma: immunohistochemical reassessment of $60 \mathrm{t}(\mathrm{X} ; 18)(\mathrm{SYT}-\mathrm{SSX})$-positive cases. Am J Surg Pathol. 2002 Nov;26(11):1434-40. PubMed PMID: 12409719.

Pen AE, Jensen UB. Current status of treating neurodegenerative disease with induced pluripotent stem cells. Acta Neurol Scand. 2017 Jan;135(1):57-72. doi: 10.1111/ane.12545. Epub 2016 Jan 8. Review. PubMed PMID: 26748435. 
Petersen I, Bujard M, Petersen S, Wolf G, Goeze A, Schwendel A, Langreck H, Gellert K, Reichel M, Just K, du Manoir S, Cremer T, Dietel M, Ried T. Patterns of chromosomal imbalances in adenocarcinoma and squamous cell carcinoma of the lung. Cancer Res. 1997 Jun 15;57(12):2331-5. PubMed PMID: 9192802.

Petersen I, Günther B, Mildner K, Subhi F, Knösel T, Altendorf-Hofmann A, Katenkamp D. [Update from the soft tissue tumour registry in Jena]. Pathologe. 2011 Feb;32(1):40-6. doi: 10.1007/s00292-010-1399-6. Review. German. PubMed PMID: 21170535.

Petersen I. Soft tissue sarcoma entities - Knowing the adversary. Trauma und Berufskrankheiten. 2017. https://doi.org/10.1007/s10039-017-0339-6.

Piscitelli D, Ruggeri E, Fiore MG, Rossi R, Guerriero S. Undifferentiated high-grade pleomorphic sarcoma in a blind eye with a silicone prosthesis implant: a clinico-pathologic study. Orbit. $2011 \quad$ Aug;30(4):192-4. doi:10.3109/01676830.2011.579681. PubMed PMID: 21780933.

Polo JM, Anderssen E, Walsh RM, Schwarz BA, Nefzger CM, Lim SM, Borkent M, Apostolou E, Alaei S, Cloutier J, Bar-Nur O, Cheloufi S, Stadtfeld M, Figueroa ME, Robinton D, Natesan S, Melnick A, Zhu J, Ramaswamy S, Hochedlinger K. A molecular roadmap of reprogramming somatic cells into iPS cells. Cell. 2012 Dec 21;151(7):1617-32. doi: 10.1016/j.cell.2012.11.039. PubMed PMID: 23260147 ; PubMed Central PMCID: PMC3608203.

Reya T, Morrison SJ, Clarke MF, Weissman IL. Stem cells, cancer, and cancer stem cells. Nature. 2001 Nov 1;414(6859):105-11. Review. PubMed PMID: 11689955.

Rizzino A. Sox2 and Oct-3/4: a versatile pair of master regulators that orchestrate the self-renewal and pluripotency of embryonic stem cells. Wiley Interdiscip Rev Syst Biol Med. 2009 Sep-Oct;1(2):228-236. doi: 10.1002/wsbm.12. Review. PubMed PMID: 20016762; PubMed Central PMCID: PMC2794141.

Rööser B, Attewell R, Berg NO, Rydholm A. Prognostication in soft tissue sarcoma. A model with four risk factors. Cancer. 1988 Feb 15;61(4):817-23. PubMed PMID: 3338039.

Rosai Juan. Rosai and Ackermann's surgical pathology, $10^{\text {th }}$ edition. Elsevier 2011, 25: 2105-2115

Roth JA, Enzinger FM, Tannenbaum M. Synovial sarcoma of the neck: a followup study of 24 cases. Cancer. 1975 Apr;35(4):1243-53. PubMed PMID: 163680.

Roy P, Clark MA, Thomas JM. Stewart-Treves syndrome--treatment and outcome in six patients from a single centre. Eur J Surg Oncol. 2004 Nov;30(9):982-6. PubMed PMID: 15498645. 
Rudin CM, Durinck S, Stawiski EW, Poirier JT, Modrusan Z, Shames DS, Bergbower EA, Guan Y, Shin J, Guillory J, Rivers CS, Foo CK, Bhatt D, Stinson J, Gnad F, Haverty PM, Gentleman R, Chaudhuri S, Janakiraman V, Jaiswal BS, Parikh C, Yuan W, Zhang Z, Koeppen H, Wu TD, Stern HM, Yauch RL, Huffman KE, Paskulin DD, Illei PB, Varella-Garcia M, Gazdar AF, de Sauvage FJ, Bourgon R, Minna JD, Brock MV, Seshagiri S. Comprehensive genomic analysis identifies SOX2 as a frequently amplified gene in small-cell lung cancer. Nat Genet. 2012 Oct;44(10):1111-6. doi: 10.1038/ng.2405. Epub 2012 Sep 2. PubMed PMID: 22941189; PubMed Central PMCID: PMC3557461.

Russo MV, Esposito S, Tupone MG, Manzoli L, Airoldi I, Pompa P, Cindolo L, Schips L, Sorrentino C, Di Carlo E. SOX2 boosts major tumor progression genes in prostate cancer and is a functional biomarker of lymph node metastasis. Oncotarget. 2016 Mar 15;7(11):12372-85. doi: 10.18632/oncotarget.6029. PubMed PMID: 26540632; PubMed Central PMCID: PMC4914291.

Rydholm A, Berg NO, Gullberg B, Persson BM, Thorngren KG. Prognosis for softtissue sarcoma in the locomotor system. A retrospective population-based follow-up study of 237 patients. Acta Pathol Microbiol Immunol Scand A. 1984 Sep;92(5):375-86. PubMed PMID: 6507102.

Sahmel J, Unice K, Scott P, Cowan D, Paustenbach D. The use of multizone models to estimate an airborne chemical contaminant generation and decay profile: occupational exposures of hairdressers to vinyl chloride in hairspray during the 1960s and 1970s. Risk Anal. 2009 Dec;29(12):1699-725. doi: 10.1111/j.15396924.2009.01311.x. Epub 2009 Nov 23. PubMed PMID: 19948002.

Sandberg AA, Bridge JA. Updates on the cytogenetics and molecular genetics of bone and soft tissue tumors. Synovial sarcoma. Cancer Genet Cytogenet. 2002 Feb;133(1):1-23. Review. PubMed PMID: 11890984.

Sandberg AA. Cytogenetics and molecular genetics of bone and soft-tissue tumors. Am J Med Genet. 2002 Oct 30;115(3):189-93. Review. PubMed PMID: 12407700.

Sarkar D, Shields B, Davies ML, Müller J, Wakeman JA. BRACHYURY confers cancer stem cell characteristics on colorectal cancer cells. Int J Cancer. 2012 Jan 15;130(2):328-37. doi: 10.1002/ijc.26029. Epub 2011 May 28. PubMed PMID: 21365650.

Scheel C, Weinberg RA. Phenotypic plasticity and epithelial-mesenchymal transitions in cancer and normal stem cells? Int J Cancer. 2011 Nov 15;129(10):2310-4. doi: 10.1002/ijc.26311. Epub 2011 Aug 29. PubMed PMID: 21792896; PubMed Central PMCID: PMC3357895.

Sell S, Pierce GB. Maturation arrest of stem cell differentiation is a common pathway for the cellular origin of teratocarcinomas and epithelial cancers. Lab Invest. 1994 Jan;70(1):6-22. Review. PubMed PMID: 8302019. 
Sherman M. Vinyl chloride and the liver. J Hepatol. 2009 Dec;51(6):1074-81. doi: 10.1016/j.jhep.2009.09.012. Epub 2009 Oct 1. Review. PubMed PMID: 19836850 .

Shmookler BM, Enzinger FM, Brannon RB. Orofacial synovial sarcoma: a clinicopathologic study of 11 new cases and review of the literature. Cancer. 1982 Jul 15;50(2):269-76. PubMed PMID: 6282438.

Shon W, Ida CM, Boland-Froemming JM, Rose PS, Folpe A. Cutaneous angiosarcoma arising in massive localized lymphedema of the morbidly obese: a report of five cases and review of the literature. J Cutan Pathol. 2011 Jul;38(7):560-4. doi: 10.1111/j.1600-0560.2011.01703.x. Epub 2011 Apr 26. Review. PubMed PMID: 21518378.

Smith AG. Embryo-derived stem cells: of mice and men. Annu Rev Cell Dev Biol. 2001;17:435-62. Review. PubMed PMID: 11687496.

Spurrell EL, Fisher C, Thomas JM, Judson IR. Prognostic factors in advanced synovial sarcoma: an analysis of 104 patients treated at the Royal Marsden Hospital. Ann Oncol. 2005; 16:437-444.

Stojadinovic A, Leung DH, Hoos A, Jaques DP, Lewis JJ, Brennan MF. Analysis of the prognostic significance of microscopic margins in 2,084 localized primary adult soft tissue sarcomas. Ann Surg. 2002 Mar;235(3):424-34. PubMed PMID: 11882765; PubMed Central PMCID: PMC1422449.

Suh H, Consiglio A, Ray J, Sawai T, D'Amour KA, Gage FH. In vivo fate analysis reveals the multipotent and self-renewal capacities of Sox $2+$ neural stem cells in the adult hippocampus. Cell Stem Cell. 2007 Nov;1(5):515-28. doi:10.1016/j.stem.2007.09.002. PubMed PMID: 18371391; PubMed Central PMCID:PMC2185820.

Sun C, Sun L, Li Y, Kang X, Zhang S, Liu Y. Sox2 expression predicts poor survival of hepatocellular carcinoma patients and it promotes liver cancer cell invasion by activating Slug. Med Oncol. 2013 Jun;30(2):503. doi:10.1007/s12032-0130503-1. Epub 2013 Feb 21. PubMed PMID: 23430442.

Surface LE, Thornton SR, Boyer LA. Polycomb group proteins set the stage for early lineage commitment. Cell Stem Cell. 2010 Sep 3;7(3):288-98. doi: 10.1016/j.stem.2010.08.004. Review. PubMed PMID: 20804966.

Sussman RT, Stanek TJ, Esteso P, Gearhart JD, Knudsen KE, McMahon SB. The epigenetic modifier ubiquitin-specific protease 22 (USP22) regulates embryonic stem cell differentiation via transcriptional repression of sexdetermining region Y-box 2 (SOX2). J Biol Chem. 2013 Aug 16;288(33):24234-46. doi: 10.1074/jbc.M113.469783. Epub 2013 Jun 12. PubMed PMID: 23760504; PubMed Central PMCID: PMC3745368. 
Suster S, Moran CA. Primary synovial sarcomas of the mediastinum: a clinicopathologic, immunohistochemical, and ultrastructural study of 15 cases. Am J Surg Pathol. 2005 May;29(5):569-78. PubMed PMID: 15832079.

Takahashi K, Okita K, Nakagawa M, Yamanaka S. Induction of pluripotent stem cells from fibroblast cultures. Nat Protoc. 2007;2(12):3081-9. PubMed PMID: 18079707.

Takahashi K, Yamanaka S. Induction of pluripotent stem cells from mouse embryonic and adult fibroblast cultures by defined factors. Cell. 2006 Aug 25;126(4):66376. Epub 2006 Aug 10. PubMed PMID: 16904174.

Terry J, Saito T, Subramanian S, Ruttan C, Antonescu CR, Goldblum JR, Downs-Kelly E, Corless CL, Rubin BP, van de Rijn M, Ladanyi M, Nielsen TO. TLE1 as a diagnostic immunohistochemical marker for synovial sarcoma emerging from gene expression profiling studies. Am J Surg Pathol. 2007 Feb;31(2):240-6. PubMed PMID: 17255769.

Thomson M, Liu SJ, Zou LN, Smith Z, Meissner A, Ramanathan S. Pluripotency factors in embryonic stem cells regulate differentiation into germ layers. Cell. 2011 Jun 10;145(6):875-89. doi: 10.1016/j.cell.2011.05.017. PubMed PMID:21663792; PubMed Central PMCID: PMC5603300.

Torres KE, Ravi V, Kin K, Yi M, Guadagnolo BA, May CD, Arun BK, Hunt KK, Lam R, Lahat G, Hoffman A, Cormier JN, Feig BW, Lazar AJ, Lev D, Pollock RE. Long-term outcomes in patients with radiation-associated angiosarcomas of the breast following surgery and radiotherapy for breast cancer. Ann Surg Oncol. 2013 Apr;20(4):1267-74. doi: 10.1245/s10434-012-2755-y. Epub 2012 Dec 6. PubMed PMID: 23224828; PubMed Central PMCID: PMC5036516.

Vazquez-Martin A, Cufí S, López-Bonet E, Corominas-Faja B, Cuyàs E, Vellon L, Iglesias JM, Leis O, Martín AG, Menendez JA. Reprogramming of nongenomic estrogen signaling by the stemness factor SOX2 enhances the tumorinitiating capacity of breast cancer cells. Cell Cycle. 2013 Nov 15;12(22):3471-7. doi: 10.4161/cc.26692. Epub 2013 Oct 4. PubMed PMID: 24107627; PubMed Central PMCID:PMC3906332.

Visvader JE, Lindeman GJ. Cancer stem cells in solid tumours: accumulating evidence and unresolved questions. Nzöllat Rev Cancer. 2008 Oct;8(10):755-68. doi: 10.1038/nrc2499. Epub 2008 Sep 11. Review. PubMed PMID: 18784658.

Weaver J, Billings SD. Postradiation cutaneous vascular tumors of the breast: a review. Semin Diagn Pathol. 2009 Aug;26(3):141-9. Review. PubMed PMID: 20043513.

Weina K, Utikal J. SOX2 and cancer: current research and its implications in the clinic. Clin Transl Med. 2014 Jul 4;3:19. doi: 10.1186/2001-1326-3-19. eCollection 2014. Review. PubMed PMID: 25114775; PubMed Central PMCID: PMC4126816. 
Werling AM, Doerflinger Y, Brandner JM, Fuchs F, Becker JC, Schrama D, Kurzen H, Goerdt S, Peitsch WK. Homo- and heterotypic cell-cell contacts in Merkel cells and Merkel cell carcinomas: heterogeneity and indications for cadherin switching. Histopathology. 2011 Jan;58(2):286-303. doi: 10.1111/j.13652559.2011.03748.x. PubMed PMID: 21323954.

Wilbertz T, Wagner P, Petersen K, Stiedl AC, Scheble VJ, Maier S, Reischl M, Mikut R, Altorki NK, Moch H, Fend F, Staebler A, Bass AJ, Meyerson M, Rubin MA, Soltermann A, Lengerke C, Perner S. SOX2 gene amplification and protein overexpression are associated with better outcome in squamous cell lung cancer. Mod Pathol. 2011 Jul;24(7):944-53. doi: 10.1038/modpathol.2011.49. Epub 2011 Apr 1. PubMed PMID: 21460799.

Williamson KA, Hever AM, Rainger J, Rogers RC, Magee A, Fiedler Z, Keng WT, Sharkey FH, McGill N, Hill CJ, Schneider A, Messina M, Turnpenny PD, Fantes JA, van Heyningen V, FitzPatrick DR. Mutations in SOX2 cause anophthalmia-esophageal-genital (AEG) syndrome. Hum Mol Genet. 2006 May 1;15(9):1413-22. Epub 2006 Mar 16. Erratum in: Hum Mol Genet. 2006 Jun 15;15(12):2030. PubMed PMID: 16543359.

Wong DJ, Liu H, Ridky TW, Cassarino D, Segal E, Chang HY. Module map of stem cell genes guides creation of epithelial cancer stem cells. Cell Stem Cell. 2008 Apr 10;2(4):333-44. doi: 10.1016/j.stem.2008.02.009. PubMed PMID: 18397753; PubMed Central PMCID: PMC2628721.

Wu Q, Chen X, Zhang J, Loh YH, Low TY, Zhang W, Zhang W, Sze SK, Lim B, Ng HH. Sall4 interacts with Nanog and co-occupies Nanog genomic sites in embryonic stem cells. J Biol Chem. 2006 Aug 25;281(34):24090-4. Epub 2006 Jul 13. PubMed PMID:16840789.

Yamanaka S. Induction of pluripotent stem cells from mouse fibroblasts by four transcription factors. Cell Prolif. 2008 Feb;41 Suppl 1:51-6. doi: 10.1111/j.1365-2184.2008.00493.x. Review. PubMed PMID: 18181945.

Yang J, Chai L, Fowles TC, Alipio Z, Xu D, Fink LM, Ward DC, Ma Y. Genome-wide analysis reveals Sall4 to be a major regulator of pluripotency in murineembryonic stem cells. Proc Natl Acad Sci U S A. 2008 Dec 16;105(50):1975661. doi: 10.1073/pnas.0809321105. Epub 2008 Dec 5. PubMed PMID: 19060217; PubMed Central PMCID: PMC2604985.

Yu J, Thomson JA. Pluripotent stem cell lines. Genes Dev. 2008 Aug 1;22(15):1987-97. doi: 10.1101/gad.1689808. Review. PubMed PMID: 18676805; PubMed Central PMCID: PMC2735345.

Yu J, Vodyanik MA, Smuga-Otto K, Antosiewicz-Bourget J, Frane JL, Tian S, Nie J, Jonsdottir GA, Ruotti V, Stewart R, Slukvin II, Thomson JA. Induced pluripotent stem cell lines derived from human somatic cells. Science. 2007 Dec 21;318(5858):1917-20. Epub 2007 Nov 20. PubMed PMID: 18029452. 
Zambon P, Ricci P, Bovo E, Casula A, Gattolin M, Fiore AR, Chiosi F, Guzzinati S. Sarcoma risk and dioxin emissions from incinerators and industrial plants: a population-based case-control study (Italy). Environ Health. 2007 Jul 16;6:19. PubMed PMID: 17634118; PubMed Central PMCID: PMC1948886.

Zayed H, Petersen I. Stem cell transcription factor SOX2 in synovial sarcoma and other soft tissue tumors. Pathol Res Pract. 2018 May 4. pii: S0344-0338(18)30299-1. doi: 10.1016/j.prp.2018.05.004. [Epub ahead of print] PubMed PMID: 29773426.

Züllig L, Roessle M, Weber C, Graf N, Haerle SK, Jochum W, Stoeckli SJ, Moch H, Huber GF. High sex determining region Y-box 2 expression is a negative predictor of occult lymph node metastasis in early squamous cell carcinomas of the oral cavity. Eur J Cancer. 2013 May;49(8):1915-22. doi: 10.1016/j.ejca.2013.01.005. Epub 2013 Feb 12. PubMed PMID: 23414798. 


\section{Appendix}

\section{Ehrenwörtliche Erklärung}

Hiermit erkläre ich, dass mir die Promotionsordnung der Medizinischen Fakultät der FriedrichSchiller-Universität bekannt ist,

ich die Dissertation selbst angefertigt habe und alle von mir benutzten Hilfsmittel, persönlichen Mitteilungen und Quellen in meiner Arbeit angegeben sind,

mich folgende Personen bei der Auswahl und Auswertung des Materials sowie bei der Herstellung des Manuskripts unterstützt haben: Professor Dr. Iver Petersen,

die Hilfe eines Promotionsberaters nicht in Anspruch genommen wurde und dass Dritte weder unmittelbar noch mittelbar geldwerte Leistungen von mir für Arbeiten erhalten haben, die im Zusammenhang mit dem Inhalt der vorgelegten Dissertation stehen,

dass ich die Dissertation noch nicht als Prüfungsarbeit für eine staatliche oder andere wissenschaftliche Prüfung eingereicht habe

und dass ich die gleiche, eine in wesentlichen Teilen ähnliche oder eine andere Abhandlung nicht bei einer anderen Hochschule als Dissertation eingereicht habe.

Ort, Datum

Unterschrift des Verfassers 


\section{Acknowledgment}

I would first like to thank my supervisor, Professor Dr. Iver Petersen for his choice of this very challenging topic and allowing me to utilize the advanced equipment and rare tumor-materials available in the Institute of Pathology of the University Hospital Jena. Professor Peterson's door was always open, including on weekends and holidays, whenever I ran into a trouble spot or had questions about my research. Without his guidance, constant remarks and mammoth support all along the way, this work would have never been possible.

I would also like to thank Professor Dr. Gita Mall, who was constantly on my side and helped me to successfully complete my doctorate thesis alongside with my work in the Section of Pathology at the Institute of Forensic Medicine. Without her sincere support in the administrative process and her passionate participation, the validation could not have been successfully conducted.

I would also like to acknowledge my Egyptian colleagues, Professor Dr. Emad H. El Gemeie, Associate Professor Dr. Hebat Allah M. Shaaban and Lecturer Dr. Omnia M. Badawy of the Faculty of medicine- Cairo University for their scientific contributions in this thesis, I am gratefully indebted to their very valuable comments.

I would like to thank apl. Professor Dr. Alexander Berndt for his generous and sincere support in the administrative process and guiding me in fulfilling the prerequisites' to submit a doctorate thesis.

Furthermore, I would like to thank Frau Christiane Geier, Frau Barbara Bergholz, Frau Susanne Bergmann and Frau Melanie Köhler of the Institute of Pathology of the University Hospital Jena for their time and excellent technical assistance during the practical work in the laboratories.

Finally, I must express my very profound gratitude to my parents, for providing me with unfailing support and continuous encouragement throughout my years of study and through the process of researching and writing this thesis even when we happen to live thousands of kilometers away.

Last, never the least, I want to thank my husband Associate Professor Tamer Owais for his incredible support and being an idol to me. Not only that he was always there and believed in me, but seeing him work hard and reap what he sow, has solidified my will. Thank you all. 